Früh-Green, G.L., Orcutt, B.N., Green, S.L., Cotterill, C., and the Expedition 357 Scientists Proceedings of the International Ocean Discovery Program Volume 357

publications.iodp.org

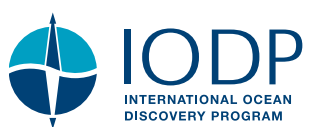

\title{
Contents
}

doi:10.14379/iodp.proc.357.101.2017

\section{Expedition 357 summary ${ }^{1}$}

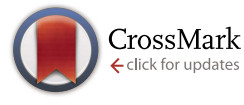

G.L. Früh-Green, B.N. Orcutt, S.L. Green, C. Cotterill, S. Morgan, N. Akizawa, G. Bayrakci, J.-H. Behrmann, C. Boschi, W.J. Brazleton, M. Cannat, K.G. Dunkel, J. Escartin, M. Harris, E. Herrero-Bervera, K. Hesse, B.E. John, S.Q. Lang, M.D. Lilley, H.-Q. Liu, L.E. Mayhew, A.M. McCaig, B. Menez, Y. Morono, M. Quéméneur, S. Rouméjon, A. Sandaruwan Ratnayake, M.O. Schrenk, E.M. Schwarzenbach, K.I. Twing, D. Weis, S.A. Whattham, M. Williams, and R. Zhao ${ }^{2}$

Keywords: International Ocean Discovery Program, IODP, RRS James Cook, Expedition 357, Site M0068, Site M0069, Site M0070, Site M0071, Site M0072, Site M0073, Site M0074, Site M0075, Site M0076, seabed drills, RD2, MeBo, Atlantis Massif, Atlantis Fracture Zone, MidAtlantic Ridge, Lost City hydrothermal field, serpentinization, detachment faulting, oceanic core complex, hydrogen, methane, deep biosphere, carbon cycling, carbon sequestration, contamination tracer testing

\section{Abstract}

International Ocean Discovery Program (IODP) Expedition 357 successfully cored an east-west transect across the southern wall of Atlantis Massif on the western flank of the Mid-Atlantic Ridge (MAR) to study the links between serpentinization processes and microbial activity in the shallow subsurface of highly altered ultramafic and mafic sequences that have been uplifted to the seafloor along a major detachment fault zone. The primary goals of this expedition were to (1) examine the role of serpentinization in driving hydrothermal systems, sustaining microbial communities, and sequestering carbon; (2) characterize the tectonomagmatic processes that lead to lithospheric heterogeneities and detachment faulting; and (3) assess how abiotic and biotic processes change with variations in rock type and progressive exposure on the seafloor. To accomplish these objectives, we developed a coring and sampling strategy centered on the use of seabed drills-the first time that such systems have been used in the scientific ocean drilling programs. This technology was chosen in the hope of achieving high recovery of the carbonate cap sequences and intact contact and deformation relationships. The expedition plans also included several engineering developments to assess geochemical parameters during drilling; sample bottom water before, during, and after drilling; supply synthetic tracers during drilling for contamination assessment; acquire in situ electrical resistivity and magnetic susceptibility measurements for assessing fractures, fluid flow, and extent of serpentinization; and seal boreholes to provide opportunities for future experiments.
Seventeen holes were drilled at nine sites across Atlantis Massif, with two sites on the eastern end of the southern wall (Sites M0068 and M0075), three sites in the central section of the southern wall north of the Lost City hydrothermal field (Sites M0069, M0072, and M0076), two sites on the western end (Sites M0071 and M0073), and two sites north of the southern wall in the direction of the central dome of the massif and Integrated Ocean Drilling Program Site U1309 (Sites M0070 and M0074). Use of seabed drills enabled collection of more than $57 \mathrm{~m}$ of core, with borehole penetration ranging from 1.30 to 16.44 meters below seafloor and core recoveries as high as $74.76 \%$ of total penetration. This high level of recovery of shallow mantle sequences is unprecedented in the history of ocean drilling. The cores recovered along the southern wall of Atlantis Massif have highly heterogeneous lithologies, types of alteration, and degrees of deformation. The ultramafic rocks are dominated by harzburgites with intervals of dunite and minor pyroxenite veins, as well as gabbroic rocks occurring as melt impregnations and veins, all of which provide information about early magmatic processes and the magmatic evolution in the southernmost portion of Atlantis Massif. Dolerite dikes and basaltic rocks represent the latest stage of magmatic activity. Overall, the ultramafic rocks recovered during Expedition 357 reveal a high degree of serpentinization, as well as metasomatic talc-amphibole-chlorite overprinting and local rodingitization. Metasomatism postdates an early phase of serpentinization but predates late-stage intrusion and alteration of dolerite dikes and the extrusion of basalt. The intensity of alteration is generally lower in the gabbroic and doleritic rocks. Chilled margins in dolerite intruded into talc-amphibole-chlorite schists are observed at the

${ }^{1}$ Früh-Green, G.L., Orcutt, B.N., Green, S.L., Cotterill, C., Morgan, S., Akizawa, N., Bayrakci, G., Behrmann, J.-H., Boschi, C., Brazleton, W.J., Cannat, M., Dunkel, K.G., Escartin, J., Harris, M., Herrero-Bervera, E., Hesse, K., John, B.E., Lang, S.Q., Lilley, M.D., Liu, H.-Q., Mayhew, L.E., McCaig, A.M., Menez, B., Morono, Y., Quéméneur, M., Rouméjon, S., Sandaruwan Ratnayake, A., Schrenk, M.O., Schwarzenbach, E.M., Twing, K.I., Weis, D., Whattham, S.A., Williams, M., and Zhao, R., 2017. Expedition 357 summary. In Früh-Green, G.L., Orcutt, B.N., Green, S.L., Cotterill, C., and the Expedition 357 Scientists, Atlantis Massif Serpentinization and Life. Proceedings of the International Ocean Discovery Program, 357: College Station, TX (International Ocean Discovery Program). http://dx.doi.org/10.14379/iodp.proc.357.101.2017

2 Expedition 357 Scientists' addresses.

MS 357-101: Published 4 February 2017 
most eastern Site M0075. Deformation in Expedition 357 cores is variable and dominated by brecciation and formation of localized shear zones; the degree of carbonate veining was lower than anticipated. All types of variably altered and deformed ultramafic and mafic rocks occur as components in sedimentary breccias and as fault scarp rubble. The sedimentary cap rocks include basaltic breccias with a carbonate sand matrix and/or fossiliferous carbonate. Fresh glass on basaltic components was observed in some of the breccias.

The expedition also successfully applied new technologies, namely (1) extensively using an in situ sensor package and water sampling system on the seabed drills for evaluating real-time dissolved oxygen and methane, $\mathrm{pH}$, oxidation-reduction potential (ORP), temperature, and conductivity during drilling; (2) deploying a borehole plug system for sealing seabed drill boreholes at four sites to allow access for future sampling; and (3) proving that tracers can be delivered into drilling fluids when using seabed drills. The rock drill sensor packages and water sampling enabled detection of elevated dissolved methane and hydrogen concentrations during and/or after drilling, with "hot spots" of hydrogen observed over Sites M0068-M0072 and methane over Sites M0070-M0072. Shipboard determination of contamination tracer delivery confirmed appropriate sample handling procedures for microbiological and geochemical analyses, which will aid all subsequent microbiological investigations that are part of the science party sampling plans and will verify this new tracer delivery technology for seabed drill rigs. Shipboard investigation of biomass density in select samples revealed relatively low and variable cell densities, and enrichment experiments set up shipboard reveal growth. Thus, we anticipate achieving many of the deep biosphere-related objectives of the expedition through continued scientific investigation in the coming years.

Finally, although not an objective of the expedition, we were serendipitously able to generate a high-resolution (20 m per pixel) multibeam bathymetry map across the entire Atlantis Massif and the nearby fracture zone, MAR, and eastern conjugate, taking advantage of weather and operational downtime. This will assist science party members in evaluating and interpreting tectonic and mass-wasting processes at Atlantis Massif.

\section{Introduction}

Drilling at Atlantis Massif focuses on two relatively recent discoveries in marine geosciences: off-axis serpentinite-hosted fluid circulation as exemplified by the Lost City hydrothermal field (LCHF) and oceanic core complexes (OCCs) as major components of slow-spreading ridges. An estimated $40 \%$ or more of the Atlantic Ocean floor was formed by interlinked processes of asymmetric extension, magmatism, and detachment faulting resulting in exposure of mantle and lower crustal rocks in OCCs (Dick et al., 2008; Cannat et al., 2006; Smith et al., 2006, 2008; Ildefonse et al., 2007; Escartín et al., 2003; Tucholke et al., 2008). OCCs incorporate highly reactive olivine-rich rocks that interact with seawater over a range of temperatures to produce both high- and low-temperature hydrothermal systems (Douville et al., 1997, 2002; Charlou et al., 1998, 2002; Sagalevich et al., 2000; Kelley et al., 2005; McCaig et al., 2007). Chemical exchange between the mantle and the hydrosphere supports abundant microbial communities in regions of focused fluid discharge in both types of systems (Schrenk et al., 2004; Takai et al., 2004; Nercessian et al., 2005; Brazelton et al., 2006; Campbell et al., 2006; Perner et al., 2007). However, it is unknown whether active microbial communities are also sustained by fluid-rock interaction in mantle-derived host rocks or in diffusely venting areas that surround focused-flow sites. At Atlantis Massif, we can study biogeochemical and tectonomagmatic processes related to three phases in the evolution of an OCC:

1. Serpentinization processes associated with active fluid discharge at the LCHF and the influence of serpentinization on microbial communities in a range of environments, including carbonate sediments, alteration in both ultramafic and mafic rocks, and zones of subsurface fluid flow of various intensities.

2. Evolution of the massif and the effects of alteration processes on microbial activity as it was progressively denuded to the seafloor and rapidly cooled from around $1 \mathrm{Ma}$ onward. This includes understanding the longevity of and possible precursors to the LCHF, determining the evolution of serpentinization with progressive denudation, and evaluating variations in microbial communities with seafloor age and as the dominant lithology changes from ultramafic to mafic in composition.

3. Early history of the detachment fault, which localized high strain deformation and fluid flow at $300^{\circ}-400^{\circ} \mathrm{C}$ (Schroeder and John, 2004; Boschi et al., 2006; Karson et al., 2006; Escartín et al., 2003), possibly as deep as several kilometers below the seafloor.

\section{Background}

\section{Active serpentinite-hosted hydrothermal systems and chemical exchange between the mantle, biosphere, and hydrosphere}

Approximately $30,000 \mathrm{~km}$ or roughly $50 \%$ of the global midocean ridges are spreading at rates $<40 \mathrm{~mm} / \mathrm{y}$ and extend from the Arctic Ocean, along the entire MAR, and into the southwest Indian Ocean. The recognition that ultramafic rocks are tectonically emplaced along major normal faults at these slow-spreading ridge environments has led to new considerations of the geophysical, geochemical, and biological consequences of serpentinization for the global marine system (Figure F1) (Cannat, 1993; Dick et al., 2003, 2008; Smith et al., 2006; Escartín et al., 2003). Serpentinization is associated with the uptake or release of many major and minor components, such as $\mathrm{H}_{2} \mathrm{O}, \mathrm{Mg}, \mathrm{Ca}, \mathrm{Si}, \mathrm{Cl}, \mathrm{Li}, \mathrm{B}, \mathrm{C}$, and $\mathrm{S}$, with important consequences for long-term global geochemical fluxes and biogeochemical cycles (Alt and Shanks, 1998, 2003, 2006; FrühGreen et al., 2004; Boschi et al., 2008; Delacour et al., 2008a, 2008b, 2008c). In addition, serpentinization reactions lead to the production of highly reduced fluids and result in high concentrations of $\mathrm{H}_{2}$ and reduced $\mathrm{C}$-species including methane, ethane, propane, and straight-chain hydrocarbons (Proskurowski et al., 2006, 2008; Konn et al., 2009; Holm and Charlou, 2001; Foustoukos and Seyfriend, 2004). These reduced species are believed to form through Sabatier or Fischer-Tropsch type (FTT) reactions catalyzed by Fe-, Ni-, and Cr-bearing minerals and have important consequences for biological activity on and within the seafloor and for global carbon cycling (Kelley et al., 2005; Takai et al., 2004; Brazelton et al., 2006; Perner et al., 2007; Proskurowski et al., 2008; Kohn et al., 2009; Holm and Charlou, 2001).

To date, six sites along the MAR-the high-temperature Rainbow, Logatchev, Ashadze, and Nibelungen fields and the lower temperature Lost City and Saldanha hydrothermal fields-are known to be hosted in mafic and ultramafic basement rocks, and more are likely to be found. Studies of the Lost City system suggest that lowto moderate-temperature ultramafic-hosted hydrothermal systems 
Figure F1. A. Conceptual sketch of lithospheric accretion and the tectonomagmatic evolution of a heterogeneous lithosphere and denudation of mantle rocks as detachment faulting progresses and OCCs are formed at slow-spreading ridges (from 2010 AGU Chapman Conference Report "Detachments in oceanic lithosphere: deformation, magmatism, fluid flow, and ecosystems," available at http://2010chapman.blogspot.fr). B. Example from Atlantis Massif: the southern wall is dominated by variably altered peridotites with gabbroic lenses (modified after Boschi et al., 2006) in contrast to (C) major gabbroic intrusions in the central dome (Grimes et al., 2008; copyright 2008 by the American Geophysical Union).

A

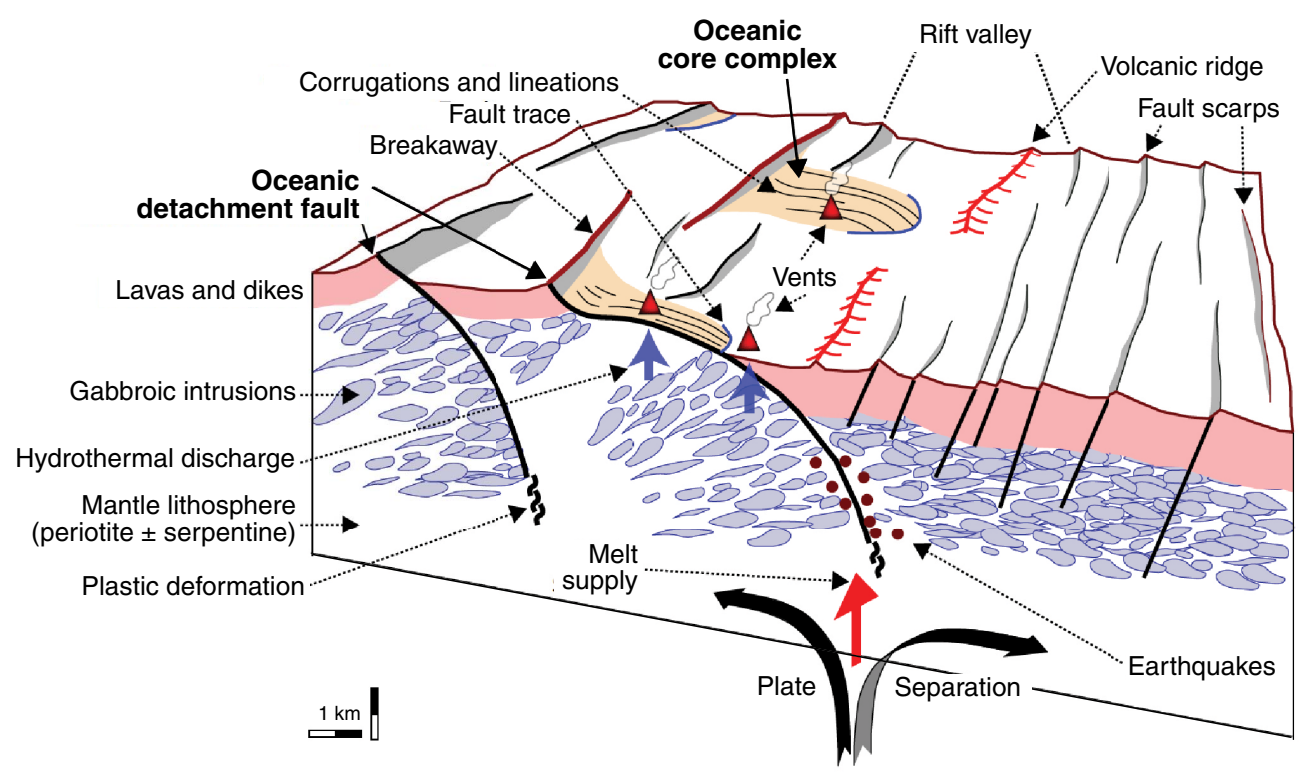

B

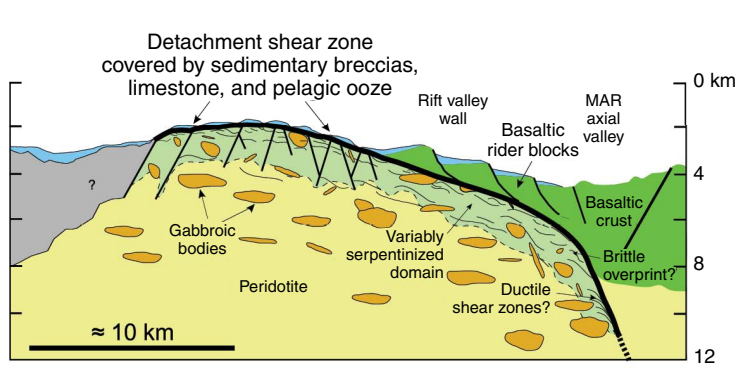

C

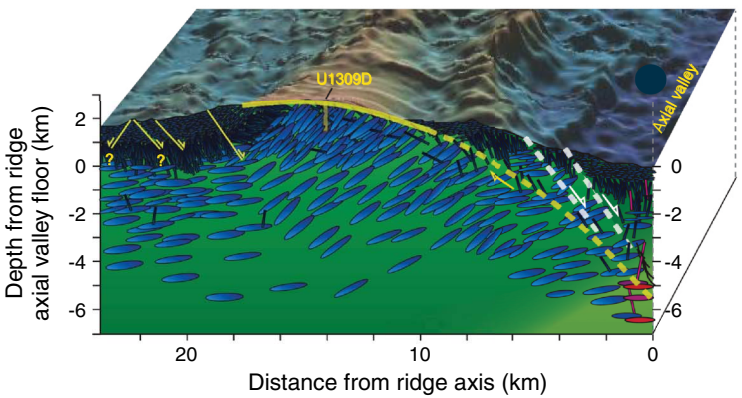

are long lived and occur in the seafloor to $2 \mathrm{Ma}$ (Ludwig et al., 2011; Früh-Green et al., 2003). Serpentinization reactions at less than $\sim 200^{\circ} \mathrm{C}$ play a key role in the production of high-pH fluids, which control carbonate precipitation and have important consequences for the sequestration of $\mathrm{CO}_{2}$ from seawater. Diffuse high-pH fluids also directly promote lithification of overlying sedimentary deposits (Früh-Green et al., 2003), which in turn affect heat flow and fluid circulation pathways. In contrast to basalt-hosted hydrothermal systems, where conceptual models of the fluid pathways, alteration reactions, and element uptake are relatively well constrained (Wheat and Fisher, 2008; Wheat et al., 2003; Fisher, 1998; Fisher and Becker, 2000), little is known of the fluid pathways and degree of heat and mass transfer that can support a subsurface biosphere in such moderate-temperature, serpentinite-hosted hydrothermal systems.

\section{Impact of serpentinization on the subsurface biosphere}

One goal of our planned drilling was to explore the subsurface environment and the potential for a hydrogen-based deep biosphere in an area undergoing active serpentinization. Lost City is characterized by extreme conditions never before seen in the deep marine environment. Carbonate-brucite structures are venting warm (temperatures up to $91^{\circ} \mathrm{C}$ ), high- $\mathrm{pH}(9-11)$ hydrothermal fluids that are metal and $\mathrm{CO}_{2}$ poor and have high concentrations of $\mathrm{H}_{2}$ (up to 15 $\mathrm{mmol} / \mathrm{kg}), \mathrm{CH}_{4}(1-2 \mathrm{mmol} / \mathrm{kg})$, organic acids, and low molecular weight hydrocarbons (Kelley et al., 2005; Proskurowski et al., 2006, 2008; Konn et al., 2009). Formate and low molecular weight hydrocarbons are believed to be formed abiologically during serpentinization reactions at depth (Lang et al., 2010, 2012). Foustoukos and Seyfried (2004) indicate that even small amounts of Cr-bearing phases typical of ultramafic rock types can enhance the synthesis of short-chain alkanes, providing an abiotic mechanism for hydrocarbon production in ultramafic-hosted hydrothermal systems ( $\mathrm{McCo}-$ llom and Seewald, 2001, 2003, 2006; McCollom, 2007). The production of $\mathrm{H}_{2}$, abiotic hydrocarbons, and possibly formate during serpentinization reactions, along with mixing with oxidized seawater, provide metabolic energy for chemolithoautotrophic and heterotrophic organisms (McCollom, 2007; McCollom and Shock, 1997). Development of an ecosystem depends on the availability 
and renewal of a carbon source, electron donors (such as $\mathrm{H}_{2}, \mathrm{CH}_{4}$, $\mathrm{H}_{2} \mathrm{~S}$, and $\mathrm{Fe}^{2+}$ ), and electron acceptors (particularly $\mathrm{O}_{2}, \mathrm{NO}_{3}^{-}$, and $\mathrm{SO}_{4}{ }^{2-}$ ). In ultramafic environments, electron donors are generally unlimited in the form of $\mathrm{H}_{2}$ and $\mathrm{CH}_{4}$, whereas electron acceptors depend greatly on the fate of sulfate (which is 1-4 $\mathrm{mM}$ in Lost City fluids) (Kelley et al., 2005) and on seawater recharge and mixing with serpentinizing fluids. Numerical models show that ultramafichosted systems may be capable of supplying about twice the metabolic energy as analogous deep-sea hydrothermal systems hosted in basaltic rocks (McCollom, 2007).

Considering the extent of ultramafic environments on the seafloor and the longevity of seawater circulation during serpentinization, the total biomass of the ultramafic-hosted subsurface biosphere may be substantial. Some researchers also propose that organic compounds produced abiotically in serpentinites may contribute to certain oil and gas reservoirs (Gold, 1979, 1999; Szatmari, 1989 ) and that similar reactions may have been the source of prebiotic organic compounds on early Earth (Holm and Andersson, 1998; Shock and Schulte, 1998; Sleep et al., 2004). Conditions of early Earth were likely similar to the hydrogen-rich anaerobic environment within the subsurface of Lost City, and the alkaline conditions are favorable for some aspects of prebiotic chemistry, such as formation of RNA-bearing vesicles (Russell, 2003). Despite the potential importance of a subsurface hydrogen-based biosphere, it has not been well studied. Previous studies of ultramafic-hosted hydrothermal systems concentrated on active vent areas and their hydrothermal deposits (Schrenk et al., 2004; Takai et al., 2004; Nercessian et al., 2005; Brazelton et al., 2006, 2009, 2010; Perner et al., 2007; Brazelton and Baross, 2009). Because of the significant difference in volatile compositions and limited $\mathrm{CO}_{2}$ stability at high $\mathrm{pH}$, one can expect that biotopes hosted in serpentinizing environments will differ significantly from axial basaltic-hosted vent systems in which $\mathrm{CO}_{2}$ is a dominant volatile species (Perner et al., 2007; Proskurowski et al., 2004, 2006, 2008; McCollom and Seewald, 2006; McCollom, 2007). In addition, the mixing of oxidized seawater with highly reduced fluids leads to complex 3-D gradients in fluid chemistry and temperature that may influence microbial distribution and activity. Substantially different habitats harboring various types of aerobic and anaerobic metabolisms may thus occur over a narrow spatial scale. However, essentially nothing is known from in situ studies of the nature and importance of microbial communities in serpentinizing basement rocks and in areas of diffuse flow or how these vary with lithology and seafloor age. In addition, little is known about the role microbes play in controlling fluid compositions and carbonate precipitation (Dupraz et al., 2009; Ehrlich, 2009).

\section{Carbon budget of hydrothermal circulation}

Large-amplitude anomalies exhibiting very low total dissolved manganese/methane ratios in the water column above faultbounded peridotite bodies confirm that seawater-peridotite interactions generate extensive $\mathrm{CH}_{4}$ plumes (Charlou et al., 1991, 1998; German et al., 2009; Bougault et al., 1993; Rona et al., 1992). Additional evidence that considerable volumes of hydrocarbons may be generated during serpentinization processes is provided by pore waters sampled during Ocean Drilling Program (ODP) Leg 125 at a serpentinized seamount in the Mariana fore arc, where high concentrations of $\mathrm{CH}_{4}$ and $\mathrm{C}_{2} \mathrm{H}_{6}$ were measured (Haggerty, 1991; Mottl and Haggerty, 1989). These studies imply that a significant amount of carbon is transferred from the upper mantle to the hydrosphere through serpentinization processes.
Stable isotope and radiocarbon measurements on methane venting at Lost City demonstrate that methane is ultimately derived abiotically from mantle $\mathrm{CO}_{2}$ as opposed to seawater bicarbonate (Proskurowski et al., 2008) and imply that seawater bicarbonate carried with recharge fluids is largely removed, presumably in carbonate minerals, before the abiotic reactions that form methane occur. This process is consistent with similar studies of $\mathrm{CO}_{2}$ in high-temperature fluids from the Endeavour segment of the Juan de Fuca Ridge (Proskurowski et al., 2004) that indicate a magmatic source of carbon in hydrothermal fluids that were venting after a 1999 earthquake and require that a large fraction of seawater bicarbonate originally present in downwelling fluids is removed during hydrothermal circulation. Extraction of seawater bicarbonate during recharge processes at the LCHF is substantiated by stable isotope compositions of calcite veins in the basement rocks (FrühGreen et al., 2003) that point to a dominant seawater component in the fluids at the time of calcite precipitation. Thus, the calcite vein networks in the Atlantis Massif footwall indicate seawater recharge pathways during the lifetime of the system that provide local domains for mixing of oxidizing seawater and reduced hydrothermal fluids with important consequences for the existence of a deep biosphere. Because of the unique relationship between $\mathrm{CO}_{2}$ and $\mathrm{CH}_{4}$ in serpentinizing systems, understanding the controls on the production and consumption of $\mathrm{CO}_{2}$ and $\mathrm{CH}_{4}$ is fundamental to understanding carbon biogeochemical cycles in these systems. At Lost City, significant quantities of $\mathrm{CO}_{2}$ are also removed from seawater in forming the chimneys themselves. In addition, oceanic serpentinites may be a previously unrecognized reservoir of organic carbon, possibly originating from dissolved organic carbon in seawater (Delacour et al., 2008c). However, it is still uncertain whether there is net fixation of carbon from the hydrosphere into the solid Earth during these processes.

When considering global carbon budgets and the potential for $\mathrm{CO}_{2}$ sequestration through carbonate precipitation in peridotites (Kelemen and Matter, 2008; Andreani et al., 2009; Boschi et al., 2009), it is important to constrain the source of carbon, the volume of carbonate, and the rate of precipitation in ultramafic-hosted hydrothermal systems and the longevity of hydrothermal circulation. In this system, there may be positive feedback in which high reaction rates are enhanced by exothermic heating during serpentinization where permeability and reactive surface area are maintained or enhanced by cracking in response to volume expansion (Kelemen and Matter, 2008). If so, quantifying carbonate precipitation during serpentinization has direct implications for evaluating the potential of in situ peridotites for $\mathrm{CO}_{2}$ capture and storage. In the case of the LCHF, although we can constrain the current focused output of the system, we do not know the large-scale patterns of recharge and more diffuse discharge or the volume of carbonate veining in the footwall and have only a minimum estimate of the longevity of the system (Früh-Green et al., 2003; Ludwig et al., 2011). To evaluate how widespread Lost City-type intermediate-temperature systems are in slow-spreading environments and to what distance from the ridge axis seawater circulation and serpentinization persist, we need a better understanding of the controls on the location of the LCHF, as well as spatial and temporal constraints on serpentinization and carbonate precipitation. Much remains to be understood about the necessary conditions (pressure, temperature, mineral reactions, and fluid fluxes) to form carbonate deposits and the controls on fluid circulation and its role in supporting a subsurface biosphere. 


\section{The evolution of hydrothermal circulation associated with detachment faulting}

Another important question to address through drilling concerned the links between detachment faults, deformation, and hydrothermal circulation that feed high-temperature mid-ocean-ridge vent fields. Research on detachment faulting and OCCs indicates that this style of oceanic spreading is intimately linked to hydrothermal circulation and encompasses a wide variety of fluid flow and hydrothermal regimes (McCaig et al., 2007). High-temperature fluid circulation is well documented mineralogically and geochemically (Schroeder and John, 2004; Boschi et al., 2006; McCaig et al., 2010), and uplift along detachments may promote circulation and alteration within the footwall (Andreani et al., 2007). McCaig et al. (2007) propose temporal evolution in the style of hydrothermal circulation associated with the development of OCCs: from high-temperature systems hosted in the basaltic hanging wall within the rift valley (e.g., Trans-Atlantic Geotraverse [TAG]-type), to high-temperature ultramafic-hosted systems within the footwall (Rainbowtype), and ultimately to off-axis ultramafic-hosted systems within the footwall (Lost City-type). At Atlantis Massif we can study the first and third of these circulation types.

Recent estimates suggest that focused flow in large high-temperature hydrothermal fields may dominate the transfer of much of the total heat from the ridges to the oceans in slow-spreading environments (German et al., 2009) and are therefore fundamental in the thermal evolution of our planet. Sampling at different locations along the former detachment fault will allow us to evaluate records of fluid-rock interaction and metasomatism and test the hypothesis that exhumation faults serve as long-lived permeable pathways for hydrothermal flow that can feed moderate- to high-temperature hydrothermal vents (McCaig et al., 2007). In ultramafic/mafic systems, assemblages of talc-tremolite-chlorite form at $>350^{\circ} \mathrm{C}$ (Boschi et al., 2006, 2008; McCaig et al., 2010), typical of black smoker discharge zones, whereas serpentine-prehnite-hydrogarnet assemblages form at lower temperatures (Frost et al., 2008; Bach and Klein, 2009). Spatially constrained sampling of the Atlantis Massif detachment system gives us an opportunity to map these variations in metamorphic assemblages, which in combination with geochemical and isotopic studies will help constrain temperatures and fluid-rock ratios (Delacour et al., 2008d).

\section{Tectonomagmatic processes at asymmetric slow-spreading ridges}

OCCs are exposed in volcanic-poor areas where detachment faults remain active over periods of 1 to $3 \mathrm{My}$. These faults accommodate slip of up to $125 \mathrm{~km}$ (e.g., the Godzilla Mullion [Ohara et al., 2001, 2002]), implying that an extremely weak zone of localized strain is maintained for significant periods of time. The envisaged mechanisms controlling long-lived stretching of the lithosphere along oceanic detachment faults call for feedback with hydrothermal fluid flow along the fault and the growth of weak hydrous minerals (notably serpentine and talc) that favor localization of ongoing deformation (Escartín et al., 2008). This process involves a crackseal mechanism associated with fluid circulation and mineral precipitation and could be a candidate for the generation of low-magnitude microseismicity.

Numerous recent geophysical and geological studies, as well as drilling at ODP and Integrated Ocean Drilling Program Sites 735B, 1275, and U1309 (Ildefonse et al., 2007; Dick et al., 2000; Kelemen et al., 2007; Expedition 304/305 Scientists, 2006) have changed our view of how slow-spreading ridges operate. Magmatic activity is locally relatively high, as evidenced by an abundance of gabbros/diabase exposed and drilled in these regions. (e.g., at Site U1309; Expedition 304/305 Scientists, 2006). The unexpected abundance of gabbro hosted by mantle peridotite suggests that significant quantities of melt are generated beneath these volcanic-poor ridge segments, but much is trapped in the mantle as it turns into lithosphere beneath the ridge axis, rather than migrating upward to form a continuous magmatic crust (Figure F1). Ongoing magmatic activity associated with asymmetric normal faulting results in a heterogeneous mafic and ultramafic lithosphere with diabase intrusions exposed in the denuded footwall, whereas accretion of volcanic seafloor persists in the hanging wall (Cannat et al., 2006; Smith et al., 2006; Ildefonse et al., 2007; Karson et al., 2006). These results are consistent with recent numerical models that suggest about $50 \%$ of ridge extension must be accommodated by magmatic accretion to allow low-angle detachment faults to develop (Tucholke et al., 2008). This magmatic activity is probably essential to initiate and maintain large high-temperature hydrothermal systems (McCaig et al., 2007; Rona et al., 1993; Lalou et al., 1995; deMartin et al., 2007; Humphris and Cann, 2000; Cannat et al., 2004) and provides crucial feedback mechanisms between hydration-promoted melting, hydration, detachment faulting, and mass transfer (Jöns et al., 2009; Escartín et al., 2008; Reinen et al., 1991; Moore and Rymer, 2007; Scruggs, 1997).

Understanding the links between faults in the brittle axial domain and deformation of the deeper ductile lithosphere is a key parameter for determining the mechanisms accommodating plate separation at mid-ocean ridges characterized by roughly equal partitioning of tectonic and magmatic spreading. Detachment faults are thought to initiate as high-angle normal faults extending $\sim 8-10$ $\mathrm{km}$; hence, the exhumed footwall provides a cross section through the upper part of the lithosphere (Figure F1). We proposed to sample the exposed, and therefore inactive, section of the Atlantis Massif fault system. Rocks recovered from near the breakaway (western side of the massif) originated from shallow depths, and rocks from the easternmost side originated from depths of several kilometers. We did not plan to drill deep into the footwall, as this was achieved during Integrated Ocean Drilling Program Expedition 304/305.

\section{Drill sites}

\section{Southern wall of Atlantis Massif}

The southern wall of Atlantis Massif is cut by steep normal faults that, together with mass wasting, expose a cross section of the lithosphere along a near-vertical, $3800 \mathrm{~m}$ high scarp north of the Atlantis Fracture Zone (Figure F2). Extensive submersible and dredge sampling along this scarp recovered primarily serpentinized ultramafic rocks $(\sim 70 \%)$ with interspersed lenses of gabbroic rocks ( 30\%) (Kelley et al., 2005; Schroeder and John, 2004; Boschi et al., 2006; Karson et al., 2006; Blackman et al., 2002). These samples of peridotites are primarily depleted spinel harzburgites and are affected by variable but high degrees of serpentinization (in general $70 \%-100 \%)$. An approximately $100 \mathrm{~m}$ thick zone of heterogeneous deformation and metamorphic assemblages considered to represent the zone of detachment faulting (Karson et al., 2006) was previously mapped for at least $3 \mathrm{~km}$ along the crest of the Atlantis Massif southern wall in the vicinity of the LCHF. Within this zone, strain localization and focused fluid flow is marked by the presence of centimeter- to decimeter-thick domains of mylonitic serpentinized peridotites and metasomatic talc-rich and/or amphibole-chlorite- 
Figure F2. Location of cored sites (RD2 and MeBo) overlain on multibeam bathymetry acquired during Expedition 357 (multibeam resolution $=50 \mathrm{~m}$ ). Cored sites from Expedition 304/305 and proposed Expedition 357 sites that were not drilled are also shown.

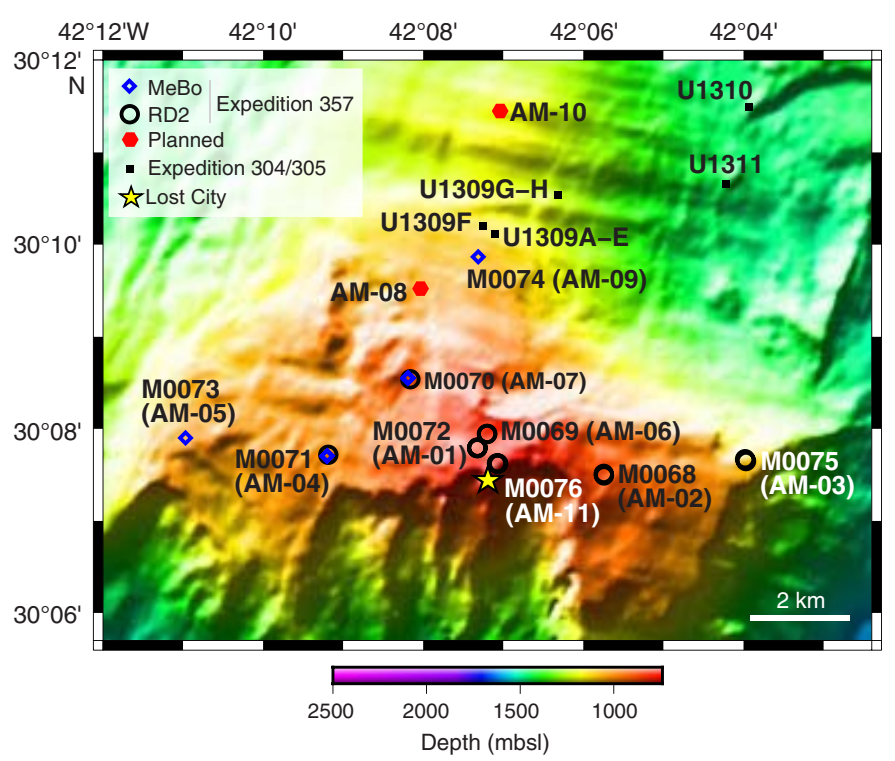

rich rocks that form shear zones with anastomosing to laminated foliations surrounding less deformed peridotites and gabbro (Schroeder and John, 2004; Boschi et al., 2006; Karson et al., 2006). Fresh high-temperature peridotite mylonites locally preserve unaltered olivine relics, which suggests an early high-temperature history of the fault zone (Schroeder and John, 2004; Boschi et al., 2006, 2008). These observations indicate that the detachment cannot be considered a single fault boundary between deformed and undeformed rocks but is rather a broad "damage" zone with localized high-strain deformation within a heterogeneous upper mantle section. Pelagic limestones and sedimentary breccias with basaltic and serpentinite clasts cover the zone of detachment faulting and form a nearly flat-lying sedimentary cap (Figure F3) believed to act as a barrier for heat and hydrothermal fluids (Kelley et al., 2005; Karson et al., 2006; Früh-Green et al., 2003; Schroeder et al., 2002).

\section{Lost City hydrothermal field}

The LCHF extends more than $400 \mathrm{~m}$ in length, with numerous active and inactive carbonate-brucite structures up to $60 \mathrm{~m}$ in height hosting dense microbial communities with limited phylogenetic diversity (Schrenk et al., 2004; Brazelton et al., 2006; Mehta and Baross, 2006). The high-temperature anoxic interior zones of the chimneys harbor biofilms dominated by a single phylotype of archaea, referred to as Lost City Methanosarcinales, whereas bacteria phylogenetically related to $\mathrm{CH}_{4}$ - and $\mathrm{S}$-oxidizers are mostly found in the oxygenated outer walls of carbonate chimneys, where fluid chemistry is influenced by the ingress and mixing of seawater (Kelley et al., 2005; Schrenk et al., 2004; Brazelton et al., 2006; Lang et al., 2012; Denny et al., 2015).

Older nonventing sites are dominated by a single phylotype belonging to the ANME-1 clade of anaerobic methane-oxidizing archaea (Brazelton et al., 2006). Organic geochemical studies identified archaeal biomarkers in the chimneys that include isoprenoid hydrocarbons, glycerol diphytanyl diethers, glycerol dibiphytanyl glycerol tetraethers (Bradley et al., 2009a, 2009b; Méhay et al., 2009, 2013), and bacterial biomarkers that include fatty acids, al- cohols, hopanoids, and nonisoprenoidal diethers. The integration of genomic data (Brazelton et al., 2006, 2009, 2010; Brazleton and Baross, 2009) and compound-specific isotope characterization of lipid biomarkers indicate variations in metabolism involving methanogenesis, methane and sulfur oxidation, and sulfate reduction over small scales during biofilm growth. Analyses of organic carbon in the hydrothermal deposits show that up to $50 \%$ of the microbial biomass is synthesized from this mantle carbon in areas where sulfate reduction is important (Lang et al., 2012). These studies imply that a significant amount of abiogenic carbon can be transferred from upper mantle domains to the biosphere and hydrosphere through serpentinization processes. A study utilizing next-generation sequencing technology shows that the archaeal and bacterial biofilm communities undergo dramatic changes as environmental conditions in Lost City chimneys change over time (Brazelton et al., 2010). Microorganisms that comprise a small fraction of the community in the hottest, youngest chimneys may be the dominant species in older chimneys with different mineralogy and fluid chemistry. This observation indicates that these species can remain in the rare biosphere for at least hundreds of years before they find themselves in conditions for which they were optimally adapted. Sampling the proposed Atlantis Massif transect may reveal dynamics of the rare biosphere operating on even longer timescales.

Fracture and fault networks in the basement below Lost City provide pathways for the fluids both vertically, forming the spire structures, and horizontally, forming carbonate growths parallel to the foliation in the serpentinites (Kelley et al., 2001, 2005; Ludwig et al., 2006; Denny et al., 2015). The nearly horizontal sheet-like style of flow is very different from the vertical conduits that typify black smoker environments (Kelley et al., 2005). Field mapping and observations indicate that fluid expulsion also occurs along steep fractures that extend into the carbonate cap sediments (Figure F3).

\section{Central dome of Atlantis Massif}

Expedition 304/305 targeted the central dome of Atlantis Massif. Drilling into the footwall was exceptionally successful in Hole U1309D (1656 m water depth), resulting in a stable $1415.5 \mathrm{~m}$ deep hole with very high average recovery (75\%) (Expedition 304/305 Scientists, 2006; Expedition Scientific Party, 2005a, 2005b). However, the recovered lithology was unexpected: extremely limited proportions $(<0.3 \%)$ of mantle peridotite but a predominance of gabbro (91.4\%; mostly very primitive), ultramafic intrusive sequences (including troctolites; 5.7\%), and diabase (3\%). Drilling results suggest that the gabbro body is a discrete body hosted within a mantle protolith (Ildefonse et al., 2007; Expedition 304/305 Scientists, 2006). Drilling at Site U1309 was instrumental in overturning many predrilling hypotheses and has led to a need for revised paradigms regarding processes of crustal accretion in these environments, particularly magma generation and distribution.

In general, Hole U1309D gabbros are remarkably undeformed. Evidence for talc-tremolite-chlorite schists, which mark the detachment fault on the southern wall, is confined to around $5 \mathrm{~cm}$ of intact core, clasts in fault breccia, and loose cobbles in several holes. The thickness of fault rocks cannot be more than $15 \mathrm{~m}$, as gabbros occur within $20 \mathrm{~m}$ of the seafloor, suggesting significant thinning compared with the south wall. However, the fault zone may also be expressed by several zones of breccia within the upper $120 \mathrm{~m}$ of Holes $\mathrm{U} 1309 \mathrm{~B}$ and U1309D and by a deeper zone at around 700 meters below seafloor (mbsf) (Expedition 304/305 Scientists, 2006; Expedition Scientific Party 2005a, 2005b; Michibayashi et al., 2008). Detailed paleomagnetic studies on cores from Hole U1309D 
Figure F3. Field relations in the target area along the Atlantis Massif southern wall. A. Sedimentary cap sequences overlie the detachment fault zone (consisting of variably thick zones of talc-amphibole schists within mylonitic and serpentinized peridotites) (Boschi et al., 2006; Karson et al., 2006). B. These sequences underlie hydrothermal deposits in the vicinity of the LCHF and overlie the detachment shear zone (DSZ) (Karson et al., 2006; copyright 2006 by the American Geophysical Union). C. Above the LCHF, cap sediments are cut by hydrothermal carbonates. D. These carbonates are locally venting diffuse fluids and have microbial filaments. Images captured by the ROV Hercules (2005), courtesy of the National Oceanic and Atmospheric Administration (NOAA)'s Office of Ocean Exploration, the University of Washington, and the Institute for Exploration at the University of Rhode Island.
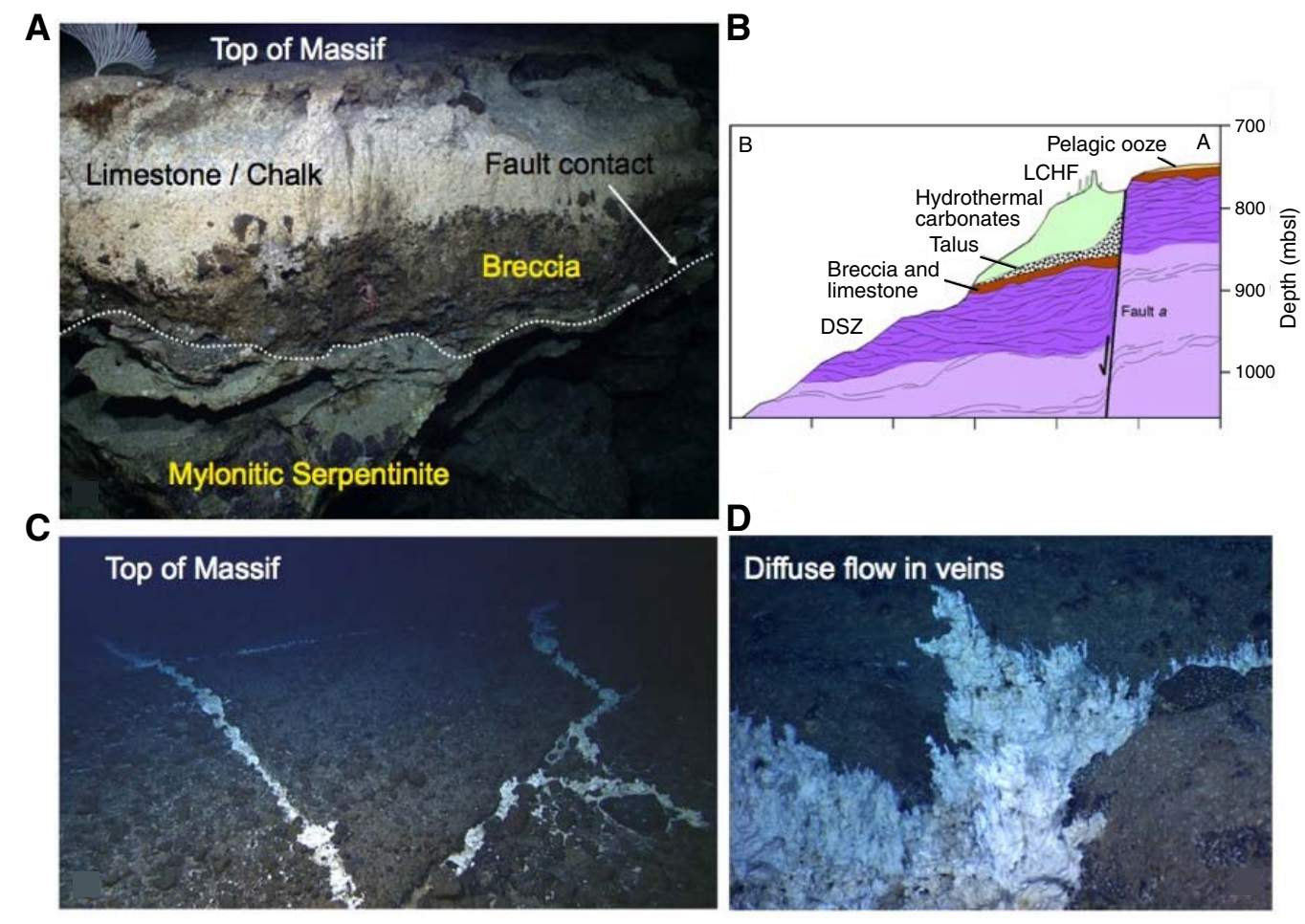

reoriented using borehole wall imagery demonstrate that the Atlantis Massif footwall has undergone a bulk tectonic rotation of at least $46^{\circ} \pm 6^{\circ}$ around a ridge-parallel $\left(011^{\circ}\right.$-trending) axis, consistent with a "rolling hinge" flexural unloading model for the detachment fault system (Morris et al., 2009). Together, these results challenge the commonly held hypothesis that the bulk rheology of slow-spreading lithosphere is primarily controlled by cooling of a simple thermal structure and instead suggest that strain localization favored by lithologic contrasts and hydrous alteration are also important, as well as perhaps highly heterogeneous cooling around large hydrothermal systems (Boschi et al., 2006; Karson et al., 2006; Escartín et al., 2003; McCaig et al., 2010).

\section{Scientific objectives}

\section{The need for shallow drilling across Atlantis Massif}

Our drilling strategy focused on obtaining good recovery of continuous sequences in the upper $50-80 \mathrm{mbsf}$, both along an eastwest profile at the top of the Atlantis Massif southern wall (in the vicinity of the LCHF) and in a north-south profile toward the central dome (where the substrate is gabbroic). Currently, almost nothing is known about the existence of a serpentinite-hosted subsurface biosphere (in any setting, marine or terrestrial), let alone its variation. Drilling the east-west profile would allow a better understanding of the evolution of the detachment fault and how microbial communities evolve as ultramafic rocks are emplaced on the seafloor. Drilling the north-south profile would allow assessment of the role of gabbros versus serpentinized ultramafic rocks in supporting ecosystems and in localizing detachment faults.
Specific hypotheses that we proposed to test by drilling were as follows:

- An extensive subsurface hydrogen-based biosphere persists in serpentinizing lithosphere. These communities evolve and adapt to variations in diffuse fluid flow, fluid chemistry, heat flow distribution, and age of exposure on seafloor aging.

- Serpentinizing environments sustain higher biomass than gabbroic-dominated domains.

- Progressive denudation and seawater interaction with ultramafic- and mafic-dominated lithosphere lead to ultramafichosted hydrothermal systems that change from high-temperature, magmatically driven sulfide deposits to low-temperature hydrothermal carbonate deposits. Moderate- to low-temperature hydrothermal activity may last for hundreds of thousands of years, and the change to carbonate-dominated systems occurs as soon as ultramafic rocks are exposed on the seafloor in the absence of active volcanism.

- The transition from sulfide- to carbonate-dominated environments can be detected by changes in the rare biosphere of the associated microbial communities.

- Zones of intense carbonate veining underlie sites of diffuse venting and represent seawater recharge and net sequestration of $\mathrm{CO}_{2}$ from the hydrosphere into the lithosphere. These zones are biological hot spots where microbial communities are supported by the high fluxes of $\mathrm{H}_{2}$ mixing with $\mathrm{CO}_{2}$.

- Strain localization on detachments results from weak serpentine-, talc-, amphibole-, and chlorite-bearing assemblages concentrated into ultramafic rather than gabbroic rocks. 


\section{Constraining the deep biosphere in a serpentinizing environment}

A major question to be addressed is whether serpentinization supports microbial communities in the basement rocks similar to those in the carbonate chimneys and fluids at the LCHF. The warmest, highest $\mathrm{pH}$ domains of carbonate chimneys are dominated by a single clade of Lost City Methanosarcinales archaea (Schrenk et al., 2004). Other organisms are apparently unable to succeed in the extreme (low $\Sigma \mathrm{CO}_{2}$, high $\mathrm{pH}$, and highly reducing) conditions of the serpentinizing fluids at temperatures approaching $100^{\circ} \mathrm{C}$. Zones where $\mathrm{CO}_{2}$ and electron acceptors such as oxygen, nitrate, and sulfate are provided by mixing ambient seawater with hydrothermal fluid harbor diverse bacteria including methane- and sulfur-oxidizing organisms.

Because fluid flow in the basement rocks is likely to be much more diffuse than the focused flow creating the Lost City chimneys, it is likely that these fluids will contain more $\mathrm{CO}_{2}$ and electron acceptors mixed in from seawater and/or not yet reduced by serpentinization reactions. Therefore, we hypothesized that microbial communities in the underlying peridotites would show greater diversity than those in the main chimney complex. Also, because of the immense volume of Atlantis Massif expected to host hydrothermal circulation, the biomass of this subsurface community could potentially dwarf that of the Lost City chimneys. In particular, primary producers utilizing $\mathrm{CO}_{2}$ from seawater and reduced species, such as $\mathrm{H}_{2}$ from serpentinizing fluids, should flourish. Sulfate is likely to be an important electron acceptor in subsurface communities because sulfate concentrations remain high in Lost City fluids (1-4 mM) (Kelley et al., 2005). We expected that domains with sufficient concentrations of sulfate will host consortia of anaerobic methane oxidizing archaea and sulfate-reducing bacteria, as observed in gas hydrates and mud volcanoes (Orphan et al., 2001). Therefore, Atlantis Massif could potentially host extensive communities dominated by both methanogens and methanotrophs. Constraining the distribution and activity of these organisms is essential for understanding biological carbon cycling through slow-spreading ocean crust.

In addition to chemolithoautotrophs, heterotrophic organisms are expected to be present in the ultramafic subsurface, where they could be supported by organic compounds generated by serpentinization. Environmental DNA sequencing of Lost City fluids (Brazelton et al., 2006, 2009, 2010; Brazelton and Baross, 2009) and lipid biomarker analyses (Bradley et al., 2009a, 2009b; Méhay et al., 2009, 2013) reveal the presence of archaeal species that are absent in the carbonate chimneys. These include 16S rRNA gene sequences belonging to Thermococcales (Euryarchaeota phylum) and uncultured Crenarchaeota, which are surprisingly similar to those in diffuse hydrothermal fluids of basalt-hosted hydrothermal systems (Brazleton et al., 2006). In such systems, the presence of these thermophilic archaea is indicative of an organic-rich, high-temperature subseafloor biotope (Summit and Baross, 2001). Although their physiology is unknown, the Thermococcales representatives are most closely related to heterotrophs, implying a source of organics in the subsurface. The proposed drill cores would allow us to directly test whether heterotrophic communities are abundant within Atlantis Massif and whether their distribution is consistent with a community supported by serpentinization-derived organic compounds.

The proposed east-west transect would also provide an excellent opportunity to explore the rare biosphere (Brazelton et al.,
2010) of subsurface communities inhabiting rocks differing in age by $\sim 1$ Ma. Virtually nothing is known about the biogeography of subsurface communities in oceanic crust. Our sampling scheme will shed light on important questions of whether microbial communities potentially adapted to magmatically driven, sulfide-dominated environments and are able to transition to serpentinizing, carbonate-dominated environments over a $\sim 1$ My timescale. Is there any overlap between the communities? At what point are the sulfideadapted organisms succeeded by carbonate-adapted organisms? Are species in the westernmost, oldest rocks already present at very rare levels in the easternmost, youngest rocks, indicating that species can remain rare for up to 1 My before "blooming"?

Some microbiological results from Expedition 305 at Atlantis Massif are available to guide our efforts (Mason et al., 2010). Rocks were collected for molecular analyses from 400 to $1400 \mathrm{mbsf}$, and aerobic bacteria were cultured in variable lithologies (gabbro and olivine-bearing gabbro) with variable $(10 \%-50 \%)$ alteration deeper than 1300 mbsf (temperature $>75^{\circ} \mathrm{C}$ ). Mason et al. (2010) had no success culturing bacteria from the troctolites, and no archaea were found. The microorganisms cultured from the central dome are most similar to organisms known to degrade hydrocarbons and are distinct from those cultured from LCHF carbonates (Schrenk et al., 2004; Brazelton et al., 2006).

\section{Importance of recovering carbonate cap sequences}

Polymictic sedimentary breccias overlain by pelagic limestones or chalks form the 1-2 m thick, flat-lying carbonate cap that was previously mapped over a large portion of the top of Atlantis Massif (Figure F3) (Kelley et al., 2001, 2005; Blackman et al., 2002). The diffusely percolating high-pH fluids emanating from the underlying serpentinites locally promoted rapid sediment lithification and may provide an important niche for microbial activity kilometers away from areas of focused flow. Recovery of intact sedimentary sequences was not possible during Expedition 304/305, and this remained a priority attainable with our proposed drilling strategy.

At present, we have no constraints on the presence, diversity, and abundance of microbial communities in the sediments. The carbonate cap was thus an important target for drilling to evaluate its role in microbial activity in a carbonate-dominated environment, one in which the chemistry (with precursor sedimentary organic and inorganic carbon sources), porosity, and temperature structure is different than those of hydrothermal carbonate towers or in basement peridotites. This environment likely supports a more diverse microbial community that may be distinct from those in the basement, carbonate chimneys, and fissure fillings. The wide lateral extent of the carbonate cap has implications for the quantification of total chemical fluxes and the diversity of ecosystems that may be supported by peridotite-hosted hydrothermal systems. If alkaline, $\mathrm{CH}_{4^{-}}$, and $\mathrm{H}_{2}$-rich fluids are emitted diffusely over a broad region, the sedimentary cap rocks represent an important biological niche for communities living in diffuse fluid flow and expands the amount of biomass that may be supported by these systems. Drilling in the sedimentary cap rocks also offers an important opportunity to constrain the depositional, diagenetic, and alteration history of these sediments. Determination of the mineralogies and fossil and lithic assemblages, combined with $\mathrm{O}$-isotope stratigraphy and radiocarbon age dating, can provide important information on the timing of microbial community shifts in relation to the evolution of detachment faulting, exhumation, and the initiation and episodicity of hydrothermal activity. 


\section{Detachment faulting and the evolution of oceanic core complexes}

Our planned drilling aimed at obtaining good, continuous recovery of the talc-amphibole-chlorite schists, serpentinite mylonites, and variably altered peridotites and gabbros that comprise the zone of detachment faulting across and along isochrons. Drilling profiles into the damage zone would constrain thickness variations of the detachment fault zone, help us better understand how strain is localized at this tectonic boundary, and document discontinuities that may reflect removal by later faulting. By drilling east-west profiles along the southern wall and north-south profiles toward the central dome and using Hole U1309D as a tie point, we would be able to document spatial and temporal heterogeneity in rock type and therefore magmatic and tectonic accommodation to plate spreading and to assess the role of rheological contrasts between competent gabbro and weaker serpentinized ultramafic rocks in localizing detachment faults. Drilling would ultimately allow a better understanding of the evolution of the massif as it was progressively uplifted to the seafloor and cooled. Although there are other OCCs where similar studies could be envisaged, Atlantis Massif is the only one currently known that also hosts a low/moderate-temperature hydrothermal system, allowing multiple objectives to be achieved within a single expedition. Thus, our study provides a unique opportunity to evaluate the extent and activity of the subsurface biosphere within a well-defined geological and geochemical context that is representative of processes that form a large proportion of the seafloor in slow-spreading ridge environments.

\section{Alignment with the IODP Science Plan}

Expedition 357 set out to drill a series of shallow ( 50-80 m) holes across Atlantis Massif ( $30^{\circ} \mathrm{N}$; MAR) in an effort to (1) recover in situ sequences of sediments, hydrothermal deposits/veins, and variably deformed metasomatic talc-amphibole-chlorite-rich rocks and serpentinized peridotites along a spreading-parallel (east-west) profile at the top of the southern wall of Atlantis Massif and (2) obtain comparable in situ sequences along a ridge-parallel (northsouth) profile on the Atlantis Massif central dome, where rock types are known to change from dominantly ultramafic to dominantly mafic.

Major scientific questions that we planned to address by drilling include the following:

- What is the nature of microbial communities hosted by serpentinizing rocks, and to what depth is microbial activity sustained? How do these vary with aging of the lithosphere? How do they differ from or interact with communities in sediments and mafic substrates in the same age crust?

- What are the consequences of serpentinization processes for global (bio)geochemical cycles?

- What are the spatial scales of lithologic and hydrothermal variability in slow-spreading lithosphere and the implications for heat and fluid fluxes and microbial life?

- How are carbon-bearing phases distributed locally and regionally? What are the rates of carbon fixation, as biomass or solid carbonate, in ultramafic rocks during low-temperature hydrothermal activity? What is the role of serpentinization in carbon sequestration?

- How do oceanic detachment faults develop and facilitate hydrothermal circulation? How do they affect the development of alteration patterns and the evolution of the deep biosphere in these environments?
Drilling Atlantis Massif provides an important opportunity to evaluate the extent and activity of the subsurface biosphere within a well-defined geological and geochemical context that is representative of processes that form a large proportion of the seafloor in slow-spreading ridge environments. The planned drilling specifically addresses fundamental questions identified in the IODP Science Plan (https://www.iodp.org/about-iodp/iodp-science-plan2013-2023) regarding Biosphere Frontiers, Earth Connections, and Earth in Motion:

- What are the origin, composition, and global significance of deep subseafloor communities?

- What are the limits of life in the subseafloor?

- How are seafloor spreading and mantle melting linked to ocean crustal architecture?

- What are the mechanisms, magnitude, and history of chemical exchanges between the oceanic crust and seawater?

- How do fluids link subseafloor tectonic, thermal, and biogeochemical processes?

The processes controlling fluid flow and a deep biosphere are intimately linked, and over the past years many studies have concentrated on understanding sedimentary or volcanic systems with high-temperature discharge or on areas of diffuse flow in volcanic units (D'Hondt et al., 2002, 2004; Shipboard Scientific Party, 2003; Expedition 301 Scientists, 2005; Nakagawa et al., 2006; Lipp et al., 2008; Parkes et al., 2005; Biddle et al., 2006; Hinrichs et al., 2006; Inagaki et al., 2006; Huber et al., 2002, 2003). In contrast, the spatial scale of lithologic variability between mafic and ultramafic seafloor at slow-spreading ridges, the implications for fluid flow paths and fluxes, and the subsurface ecosystems supported by these systems remain almost completely unconstrained. A major aim of drilling Atlantis Massif was to investigate the nature and distribution of microbial communities and their links with seawater infiltration and alteration processes in two distinct, lithologically heterogeneous domains of an OCC: (1) the serpentinizing basement at varying distances both from the ridge axis and from the active, low-temperature hydrothermal field, the LCHF, and (2) a mafic, plutonic domain sampled from Hole U1309D that is less influenced by present-day hydrothermal activity and serpentinization. Our objectives open new opportunities for the study of abiogenic production of organic compounds and their implications for prebiotic synthesis (Holm and Andersson, 1998; Shock and Schulte, 1998; Sleep et al., 2004) and will help constrain the subsurface scale and longevity of hydrothermal circulation and hence rates of carbon fixation. This study has implications both for past climate change (Kelemen and Matter, 2008; Andreani et al., 2009; Boschi et al., 2009) and possible active sequestration of $\mathrm{CO}_{2}$ in ultramafic rocks.

\section{Operational strategy}

\section{Overview of offshore operational logistics}

To achieve the expedition scientific objectives, seabed drill technology was chosen as the ideal method to recover high-quality shallow (50-70 m total length) cores from Atlantis Massif. To enable continuous operations, two seabed drills were chosen for this purpose: the Meeresboden-Bohrgerät 70 (MeBo) rock drill from the Center for Marine Environmental Sciences (MARUM; University of Bremen, Germany) and the British Geological Survey (BGS) RockDrill2 (RD2) (Figure F4). The RRS James Cook (Natural Environment Research Council [NERC], UK) was provided as an in-kind 
Figure F4. Seabed drills deployed from the RRS James Cook, Expedition 357. Top $=$ MeBo, bottom = RD2. Images courtesy of Dave Smith (BGS).

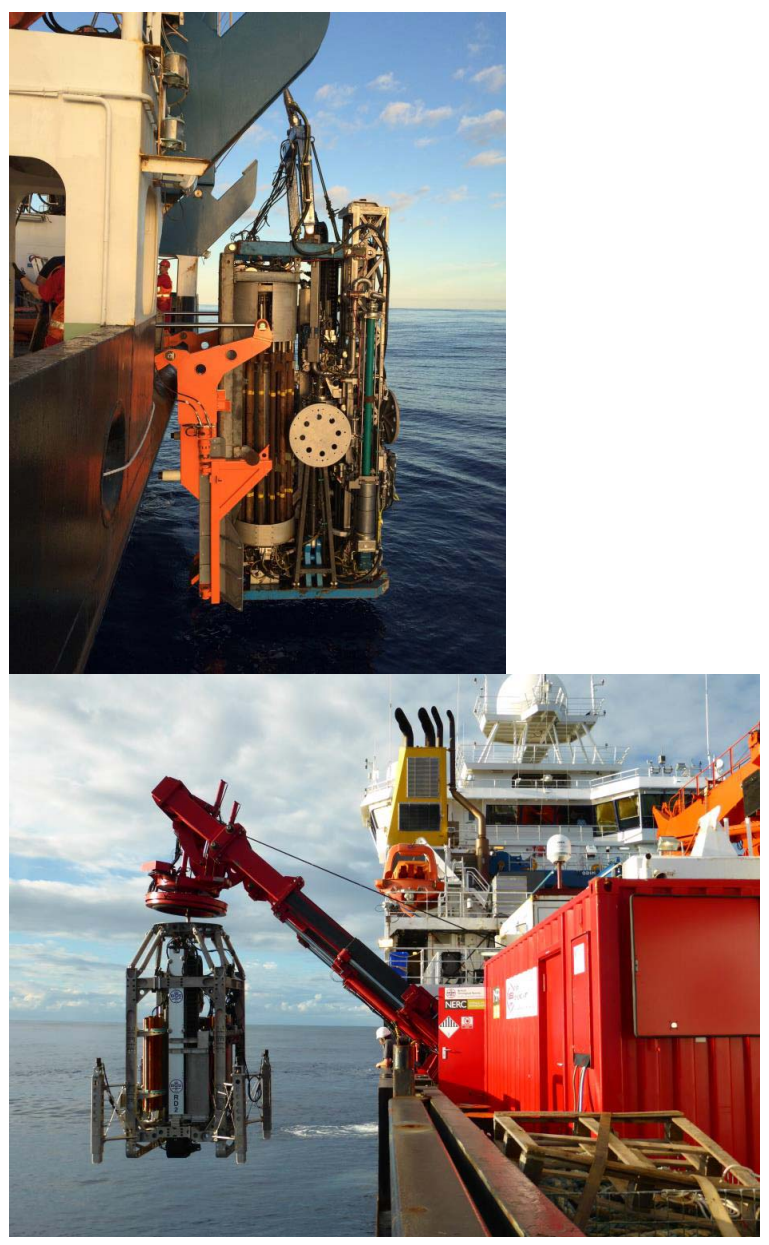

contribution as the drilling platform in support of the seabed drill operations.

This was the first time that seabed drill technology was used by the ocean drilling programs. Both drills are remotely operated systems that are lowered onto the seabed, with power and control maintained from the surface via an umbilical. The systems use multiple drill rods and core barrels to progressively penetrate into the seabed. They are both based on an HQ-size coring system, producing $61.1 \mathrm{~mm}$ diameter cores, similar in size to the standard IODP core diameter, while cutting a smaller diameter hole. By sitting on the seabed, they do not require heave compensation and consequently have good control on bit weight, analogous to land-based mining coring. Each system has the capacity to operate with either clear polycarbonate liners or stainless steel splits.

In support of the expedition's scientific objectives, several other tools were utilized in addition to the seabed drills:

- A drill-mounted water sensor + sampling package,

- A drill-mounted tracer delivery system,

- Drill rig-deployed borehole plugs,

- Cableless logging tools, and

- A conductivity, temperature, and depth (CTD) rosette system on the RRS James Cook.

Several of these tools were custom designed for this expedition. Details of these systems are provided in more detail in the Expedition 357 methods chapter (Früh-Green et al., 2017c).
Mobilization of the vessel began on 16 October 2015 in Southampton, UK. The offshore science party joined the vessel on 24 October, and the RRS James Cook sailed on 26 October. The offshore phase ran for 47 days from 26 October to 11 December when the offshore science party disembarked the vessel and demobilization began. All European Consortium for Ocean Research Drilling (ECORD) Science Operator (ESO), BGS RD2, and MARUM MeBo staff cleared the vessel by 15 December.

In total, 16.4 days of Expedition 357 were spent operational on station, 19.5 days in transit, 4.7 days on standby because of weather, and 5.4 days on equipment-related downtime. See Table T1 for a summary of offshore operations and recovery. Shipboard-generated recovery plots are available on the ECORD Atlantis Massif Serpentinization and Life Expedition website under weekly summaries (http://www.ecord.org/expedition357/reports/).

\section{Offshore operations}

Based on seismic and bathymetric data acquired during previous research in the Atlantis Massif area, 11 drill sites were proposed for investigation, encompassing an east-west transect and a northsouth transect. All holes were sited within an area approved by the Environmental Protection and Safety Panel. The general locations of the sites cored are shown in Figure F2. Table T2 details the distances between the various holes and sites.

Prior to coring operations, a multibeam survey was conducted to accurately place the break of slope against two preexisting bathymetric data sets and the proponent-provided site locations. The RRS James Cook operates a Kongsberg Simrad EM120 deep-sea multibeam echo sounder. To improve resolution and analysis of slope angles at each drill site, the beam angle on the EM120 was decreased to $45^{\circ}$. A $50 \mathrm{~m}$ resolution surface was generated within Caris HIPS and SIPS software to assess each location for slope prior to landing each rock drill. This was later supplemented by further multibeam surveys over Atlantis Massif, the Atlantis Fracture Zone, the MAR, and some of the conjugate margin when coring operations were suspended because of weather. The same swath settings were used as in the initial site survey. More details are provided in Introduction in the Expedition 357 methods chapter (Früh-Green et al., 2017c).

Operations at each site followed a similar pattern. Before commencing drilling operations, a cast of the ship's CTD was undertaken to capture a water column profile, in particular the bottom water character, prior to coring and any associated disturbance. Three Niskin bottles were fired at the bottom of the cast, two in the midwater column, and one near the surface. During drilling operations, real-time data streams from the drill-mounted sensors were monitored to track ephemeral events during penetration and operations. After drilling ceased, bottom water was taken with three $\mathrm{Ni}$ skin bottles mounted to the sensor packages to access changes in water and gas concentrations contributed by formation fluids. When suitable conditions enabled them, deployments of the cableless logging tools and/or borehole plug systems were attempted after drilling concluded. After recovery of the rock drills, water and core samples were immediately removed from the drills and brought into the laboratory for processing.

As with all mission-specific platform expeditions, no cores were split during the offshore phase; therefore, a comprehensive onshore phase complemented the offshore phase. Table T3 summarizes the descriptions and measurements made during Expedition 357 and indicates whether these were taken offshore or onshore. To prevent degradation of ephemeral samples during the offshore phase, selected whole-round cores were acquired for microbiology (see Mi- 
Table T1. Operations summary, Expedition 357. Download table in .csv format.

\begin{tabular}{|c|c|c|c|c|c|c|c|c|c|c|c|c|c|}
\hline Hole & $\begin{array}{l}\text { Proposed } \\
\text { site }\end{array}$ & $\begin{array}{l}\text { Date coring } \\
\text { operations } \\
\text { commenced } \\
\text { (Nov 2015) }\end{array}$ & Latitude & Longitude & $\begin{array}{c}\text { Water } \\
\text { depth }(m)\end{array}$ & Drill & $\begin{array}{l}\text { Number } \\
\text { of cores }\end{array}$ & $\begin{array}{l}\text { Interval } \\
\text { cored }(m)\end{array}$ & $\begin{array}{l}\text { Core } \\
\text { recovered } \\
(\mathrm{m})\end{array}$ & $\begin{array}{l}\text { Core } \\
\text { recovery } \\
(\%)\end{array}$ & $\begin{array}{c}\text { Interval } \\
\text { open-holed } \\
(\mathrm{m})\end{array}$ & $\begin{array}{l}\text { Penetration } \\
\text { depth } \\
\text { (mbsf) }\end{array}$ & $\begin{array}{l}\text { Time on site } \\
\text { (days) }\end{array}$ \\
\hline M0068A & AM-02A & 5 & $30^{\circ} 7.49^{\prime} \mathrm{N}$ & $42^{\circ} 5.74^{\prime} \mathrm{W}$ & 1102.7 & RD2 & 1 & 1.97 & 0.47 & 23.92 & 0 & 1.97 & 0.41 \\
\hline M0068B & $A M-02 A$ & 23 & $30^{\circ} 7.51^{\prime} \mathrm{N}$ & $42^{\circ} 5.75^{\prime} \mathrm{W}$ & 1102.0 & RD2 & 9 & 11.25 & 6.34 & 66.04 & 0 & 9.60 & 1.95 \\
\hline M0069A & AM-06A & 6 & $30^{\circ} 7.94^{\prime} \mathrm{N}$ & $42^{\circ} 7.20^{\prime} \mathrm{W}$ & 850.9 & RD2 & 10 & 16.44 & 12.29 & 74.76 & 0 & 16.44 & 2.04 \\
\hline M0070A & AM-07A & 8 & $30^{\circ} 8.55^{\prime} \mathrm{N}$ & $42^{\circ} 8.19^{\prime} \mathrm{W}$ & 1140.5 & MeBo & 3 & 4.00 & 2.09 & 52.25 & 0 & 4.00 & 0.94 \\
\hline М0070B & AM-07A & 14 & $30^{\circ} 8.54^{\prime} \mathrm{N}$ & $42^{\circ} 8.16^{\prime} \mathrm{W}$ & 1140.5 & RD2 & 1 & 1.30 & 0.38 & 29.23 & 0 & 1.30 & 0.22 \\
\hline M0070C & AM-07A & 22 & $30^{\circ} 8.54^{\prime} \mathrm{N}$ & $42^{\circ} 8.19^{\prime} \mathrm{W}$ & 1140.5 & MeBo & 3 & 5.21 & 2.21 & 42.42 & 0 & 5.21 & 1.3 \\
\hline M0071A & AM-04A & 9 & $30^{\circ} 7.71^{\prime} \mathrm{N}$ & $42^{\circ} 9.20^{\prime} \mathrm{W}$ & 1390.8 & MeBo & 2 & 5.22 & 2.85 & 54.60 & 0 & 5.22 & 0.75 \\
\hline M0071B & AM-04A & 18 & $30^{\circ} 7.72^{\prime} \mathrm{N}$ & $42^{\circ} 9.19^{\prime} \mathrm{W}$ & 1380.0 & RD2 & 3 & 4.31 & 2.31 & 53.62 & 0 & 4.31 & 1.1 \\
\hline M0071C & AM-04A & 25 & $30^{\circ} 7.70^{\prime} \mathrm{N}$ & $42^{\circ} 9.21^{\prime} \mathrm{W}$ & 1390.0 & MeBo & 9 & 14.26 & 4.44 & 36.54 & 0 & 12.15 & 2.6 \\
\hline M0072A & AM-01A & 10 & $30^{\circ} 7.79^{\prime} \mathrm{N}$ & $42^{\circ} 7.32^{\prime} \mathrm{W}$ & 820.3 & RD2 & 2 & 2.23 & 0.87 & 39.10 & 0 & 2.23 & 0.39 \\
\hline M0072B & AM-01A & 10 & $30^{\circ} 7.79^{\prime} \mathrm{N}$ & $42^{\circ} 7.32^{\prime} \mathrm{W}$ & 820.3 & RD2 & 8 & 11.61 & 6.49 & 52.3 & 0.83 & 12.43 & 1.69 \\
\hline M0073A & AM-05A & 14 & $30^{\circ} 7.90^{\prime} \mathrm{N}$ & $42^{\circ} 10.97^{\prime} \mathrm{W}$ & 1430.2 & MeBo & 1 & 2.20 & 0 & 0 & 0 & 2.20 & 0.44 \\
\hline M0074A & AM-09A & 30 & $30^{\circ} 9.87^{\prime} \mathrm{N}$ & $42^{\circ} 7.32^{\prime} \mathrm{W}$ & 1550.0 & MeBo & 1 & 2.68 & 0.86 & 32.09 & 0 & 2.68 & 0.23 \\
\hline M0075A & AM-03A & 28 & $30^{\circ} 7.67^{\prime} \mathrm{N}$ & $42^{\circ} 3.98^{\prime} \mathrm{W}$ & 1568.0 & RD2 & 1 & 1.72 & 0.65 & 37.79 & 0 & 1.72 & 0.57 \\
\hline M0075B & AM-03A & 29 & $30^{\circ} 7.65^{\prime} \mathrm{N}$ & $42^{\circ} 3.97^{\prime} \mathrm{W}$ & 1568.0 & RD2 & 3 & 5.70 & 2.73 & 47.88 & 0 & 5.70 & 1.1 \\
\hline M0076A & AM-11A & 15 & $30^{\circ} 7.62^{\prime} \mathrm{N}$ & $42^{\circ} 7.08^{\prime} \mathrm{W}$ & 768.0 & RD2 & 1 & 1.72 & 0.4 & 23.26 & 0 & 1.72 & 0.24 \\
\hline M0076B & AM-11A & 16 & $30^{\circ} 7.62^{\prime} \mathrm{N}$ & $42^{\circ} 7.07^{\prime} \mathrm{W}$ & 768.0 & RD2 & 10 & 16.31 & 11.71 & 71.80 & 0 & 16.31 & 2.13 \\
\hline
\end{tabular}

Table T2. Distances (in kilometers) between holes, Expedition 357. Download table in .csv format.

\begin{tabular}{|c|c|c|c|c|c|c|c|c|c|c|c|c|c|c|c|c|c|}
\hline & $\begin{array}{c}\text { Hole } \\
\text { M0068A }\end{array}$ & $\begin{array}{c}\text { Hole } \\
\text { M0068B }\end{array}$ & $\begin{array}{c}\text { Hole } \\
\text { Mo069A }\end{array}$ & $\begin{array}{c}\text { Hole } \\
\text { M0070A }\end{array}$ & $\begin{array}{l}\text { Hole } \\
\text { M0070B }\end{array}$ & $\begin{array}{c}\text { Hole } \\
\text { M0070C }\end{array}$ & $\begin{array}{c}\text { Hole } \\
\text { M0071A }\end{array}$ & $\begin{array}{l}\text { Hole } \\
\text { Mo071B }\end{array}$ & $\begin{array}{l}\text { Hole } \\
\text { Mo071C }\end{array}$ & $\begin{array}{c}\text { Hole } \\
\text { M0072A }\end{array}$ & $\begin{array}{c}\text { Hole } \\
\text { M0072B }\end{array}$ & $\begin{array}{c}\text { Hole } \\
\text { Mo073A }\end{array}$ & $\begin{array}{c}\text { Hole } \\
\text { M0074A }\end{array}$ & $\begin{array}{c}\text { Hole } \\
\text { Mo075A }\end{array}$ & $\begin{array}{c}\text { Hole } \\
\text { M0075B }\end{array}$ & $\begin{array}{c}\text { Hole } \\
\text { Mo076A }\end{array}$ & $\begin{array}{c}\text { Hole } \\
\text { Mo076B }\end{array}$ \\
\hline Hole M0068A & $x$ & 0.03 & 2.48 & 4.38 & 4.34 & 4.39 & 5.55 & 5.54 & 5.564 & 2.59 & 2.62 & 8.41 & 5.07 & 2.94 & 2.86 & 2.15 & 2.13 \\
\hline Hole M0068B & - & $x$ & 2.47 & 4.37 & 4.32 & 4.37 & 5.55 & 5.53 & 5.56 & 2.58 & 2.61 & 8.40 & 5.04 & 2.94 & 2.86 & 2.14 & 2.12 \\
\hline Hole M0069A & - & - & $x$ & 1.94 & 1.89 & 1.94 & 3.23 & 3.21 & 3.24 & 0.34 & 0.35 & 6.04 & 3.57 & 5.28 & 5.21 & 0.63 & 0.64 \\
\hline Hole M0070A & - & - & - & $x$ & 0.05 & 0.02 & 2.25 & 2.23 & 2.27 & 1.98 & 1.96 & 4.62 & 2.81 & 7.03 & 6.96 & 2.48 & 2.49 \\
\hline Hole M0070B & - & - & - & - & $x$ & 0.05 & 2.26 & 2.24 & 2.28 & 1.93 & 1.91 & 4.65 & 2.81 & 6.98 & 6.92 & 2.43 & 2.45 \\
\hline Hole M0070C & - & - & - & - & - & $x$ & 2.24 & 2.21 & 2.25 & 1.97 & 1.95 & 4.61 & 2.82 & 7.03 & 6.97 & 2.48 & 2.49 \\
\hline Hole M0071A & - & - & - & - & - & - & $x$ & 0.02 & 0.02 & 3.01 & 2.98 & 2.86 & 5.01 & 8.46 & 8.38 & 3.41 & 3.42 \\
\hline Hole M0071B & - & - & - & - & - & - & - & $x$ & 0.04 & 2.99 & 2.97 & 2.88 & 4.99 & 8.44 & 8.36 & 3.39 & 3.41 \\
\hline Hole M0071C & - & - & - & - & - & - & - & - & $x$ & 3.02 & 3.00 & 2.85 & 5.03 & 8.47 & 8.39 & 3.42 & 3.44 \\
\hline Hole M0072A & - & - & - & - & - & - & - & - & - & $x$ & 0.03 & 5.85 & 3.84 & 5.45 & 5.38 & 0.50 & 0.52 \\
\hline Hole M0072B & - & - & - & - & - & - & - & - & - & - & $x$ & 5.82 & 3.84 & 5.48 & 5.41 & 0.53 & 0.54 \\
\hline Hole M0073A & - & - & - & - & - & - & - & - & - & - & - & $x$ & 6.90 & 11.30 & 11.23 & 6.26 & 6.28 \\
\hline Hole M0074A & - & - & - & - & - & - & - & - & - & - & - & - & $x$ & 6.78 & 6.75 & 4.17 & 4.18 \\
\hline Hole M0075A & - & - & - & - & - & - & - & - & - & - & - & - & - & $x$ & 0.09 & 5.055 & 5.04 \\
\hline Hole M0075B & - & - & - & - & - & - & - & - & - & - & - & - & - & - & $x$ & 4.98 & 4.96 \\
\hline Hole M0076A & - & - & - & - & - & - & - & - & - & - & - & - & - & - & - & $x$ & 0.02 \\
\hline Hole M0076B & - & - & - & - & - & - & - & - & - & - & - & - & - & - & - & - & $x$ \\
\hline
\end{tabular}

Table T3. Summary of measurements, Expedition 357. MSCL = multisensor core logger, $\mathrm{PFC}=$ perfluorocarbon, $\mathrm{DIC}=$ dissolved inorganic carbon, $\mathrm{DOC}=$ dissolved organic carbon, $\mathrm{POC}=$ particulate organic carbon, $\mathrm{GC}=$ gas chromatograph, IW = interstitial water, ICP-OES = inductively coupled plasma-optical emission spectrometry, IC = ion chromatography, TOC = total organic carbon, TC = total carbon, TS = total sulfur, LECO = carbon/sulfur analyzer. Download table in .csv format.

\begin{tabular}{|c|c|}
\hline RRS James Cook, offshore Atlantis Massif & Onshore science party, $\mathrm{BCR}$ \\
\hline Through-liner core description & Natural gamma radiation (whole core) \\
\hline $\begin{array}{l}\text { Whole-core MSCL logging (fast and slow tracks): density, velocity, magnetic susceptibility, } \\
\text { electrical resistivity }\end{array}$ & $\begin{array}{l}\text { Core description (through liner and on split archive halves) } \\
\text { Thin section description }\end{array}$ \\
\hline PFC contamination tracer concentration determination & IW analysis by ICP-OES (major and trace elements) and IC (chloride, bromide, sulfate, and \\
\hline Microbiology cell counts (by fluorescent microscope) & nitrate) and sediment TOC, TC, and TS by LECO \\
\hline \multirow{3}{*}{$\begin{array}{l}\mathrm{pH} \text { by ion-specific electrode; alkalinity by single-point titration to } \mathrm{pH} \text {; salinity by } \\
\text { refractometer; ammonium by flow injection method; methane and hydrogen by GC } \\
\text { Microbiology whole-round core photography }\end{array}$} & $\mathrm{pH} / \mathrm{alkalinity} \mathrm{calibration} \mathrm{measurements}$ \\
\hline & High-resolution continuous digital line scanning $\left(360^{\circ}\right.$ through liner, wet and dry on split \\
\hline & working and archive halves) \\
\hline Downhole logging (through-pipe gamma ray) & Discrete sample moisture and density properties \\
\hline \multirow[t]{3}{*}{ In situ sensor measurement of dissolved gas, $\mathrm{pH}$, and temperature } & Discrete sample magnetic susceptibility and paleomagnetic measurements \\
\hline & Handheld color reflectance of split core surfaces (archive half) \\
\hline & Discrete triaxial $P$-wave velocity measurements \\
\hline
\end{tabular}

crobiology), and core material and water samples were obtained for analyses of gases and geochemistry (see Fluid chemistry). Offshore analyses for contamination were conducted on drill fluid samples taken during operations (see Microbiology). All microbiology and geochemistry samples acquired offshore for postexpedition research were shipped either directly back to the requestor's home 
laboratory or, for the pooled microbiology samples, directly to the Kochi Core Center (Japan) for later processing by members of the science party. All samples were shipped under controlled temperature conditions.

\section{Onshore Science Party}

The cores and geochemistry splits collected offshore were transported under refrigeration to the IODP Bremen Core Repository (BCR) at MARUM. Further analytical laboratories were accessed at MARUM (nondestructive core logging, marine geotechnics, and inorganic geochemistry) and the Department of Geosciences at the University of Bremen (paleomagnetism and the carbon/sulfur analysis system).

Prior to the Onshore Science Party (OSP), natural gamma radiation (NGR) measurements were conducted on all cores. In addition, continuous digital line scanning was conducted on each core through the liner, with four passes per core. After each pass, the core was rotated $90^{\circ}$, resulting in a composite $360^{\circ}$ whole-core image (see Physical properties).

During the OSP (20 January-4 February 2016), the cores were described in detail and IODP minimum and standard measurements were undertaken (Table T3). In addition, sampling for postexpedition scientific research was undertaken.

\section{Summary of achievements}

Expedition 357 was the first IODP expedition to utilize seabed drills to acquire subsurface core material. Although there were some technical challenges, as is to be expected when using such complex systems in the subsea environment, the method worked well, with recovery of coherent material from a wide range of lithologies and degrees of deformation. The total core recovered by the two seabed drills was $57 \mathrm{~m}$ after $105 \mathrm{~m}$ of total penetration, with an overall recovery of $53 \%$ at nine different sites. Two holes north of the LCHF were drilled to nearly $16.5 \mathrm{mbsf}$, with an average core recovery of $71 \%-75 \%$. Such high recovery in shallow mantle sequences is unprecedented in the history of ocean drilling. The cored sections were highly heterogeneous, ranging from moderately to highly altered and deformed serpentinized peridotites with varying compositions and occurrences of talc-amphibole-schist zones and dolerites. Less abundant lithologies included lithified basalt breccias, rodingites, and metagabbros with cataclastic to (ultra)mylonitic deformation fabrics.

In addition to recovering lower crustal and upper mantle sequences of the Atlantis Massif detachment fault zone, advancements in seabed drill rig technology funded by ECORD were achieved during Expedition 357. For the first time, four borehole plug systems were installed by the RD2 drill, two of which we are confident were well seated in the formations. These borehole plugs will enable future sampling of formation fluid from the boreholes to understand geochemical and microbiological processes in an actively serpentinizing system. New sensor packages designed for the expedition were highly successful and consistently delivered realtime chemical information while drilling, allowing in situ confirmation of ephemeral events such as gas release during penetration. Finally, a new pump system was proven to deliver a geochemical tracer during drilling for reliable contamination tracer testing.

The European Petrophysics Consortium worked with both drill teams and ANTARES Datensysteme GmbH (Germany) to develop two memory logging tools that could be stored in the tool rack of either drill system and deployed cableless downhole. Although we were unable to deploy these systems in the open hole during the expedition because of unsuitable hole conditions, this was another key technological development that enhances the operational capability of seabed drills for future projects.

\section{Principal expedition results Multibeam bathymetry}

During Expedition 357, a multibeam bathymetry survey was conducted over Atlantis Massif, portions of the conjugate margin across the MAR, and along the Atlantis Fracture Zone to the south. The new bathymetry provides a grid with a resolution of $20-50 \mathrm{~m}$ per pixel (Figures F5, F6), which is two to five times higher resolution than previously available bathymetry for this area (100 m per pixel) (Blackman et al., 2002). The survey covers the entire striated detachment fault surface and surrounding terrain, including the ridge axis to the east, the Atlantis Fracture Zone to the south, the tectonized terrain off-axis and west of the detachment, and its gradual narrowing transition to the adjacent seafloor to the north (Figures F6, F7).

The striated detachment surface shows variations in geometry along-axis from south to north. Near the transform wall (south), the detachment fault surface summits near the LCHF at $<800$ meters below sea level (mbsl); from there it dips $\sim 8^{\circ}$ east toward the ridge axis, $\sim 6^{\circ}$ west (Figure F7), and $\sim 8^{\circ}-10^{\circ}$ north toward the central dome. The detachment deepens to the north to $>1500 \mathrm{mbsl}$. This deepening is associated with a change in shape; the detachment shows curvature along the spreading direction with slopes of up to $15^{\circ}$ at its termination toward the ridge axis, becomes subhorizontal, and dips up to $10^{\circ}$ away from the axis. Across-axis profiles at different locations along Atlantis Massif in Figure F8 show the position of the holes from Expedition 357 and the cored depth at Hole U1309D drilled during Expedition 304/305.

The hanging wall cutoff (termination) is well preserved toward the northern, deeper part of Atlantis Massif, corresponding to a sharp contact between the ridgeward-dipping striated fault plane and the adjacent seafloor volcanic terrain. This volcanic terrain has a $\sim 5^{\circ}$ to $10^{\circ}$ tilt westward, away from the ridge axis, and hosts volca-

Figure F5. Multibeam image of Atlantis Massif data set acquired at $20 \mathrm{~m}$ per pixel resolution acquired during Expedition 357.

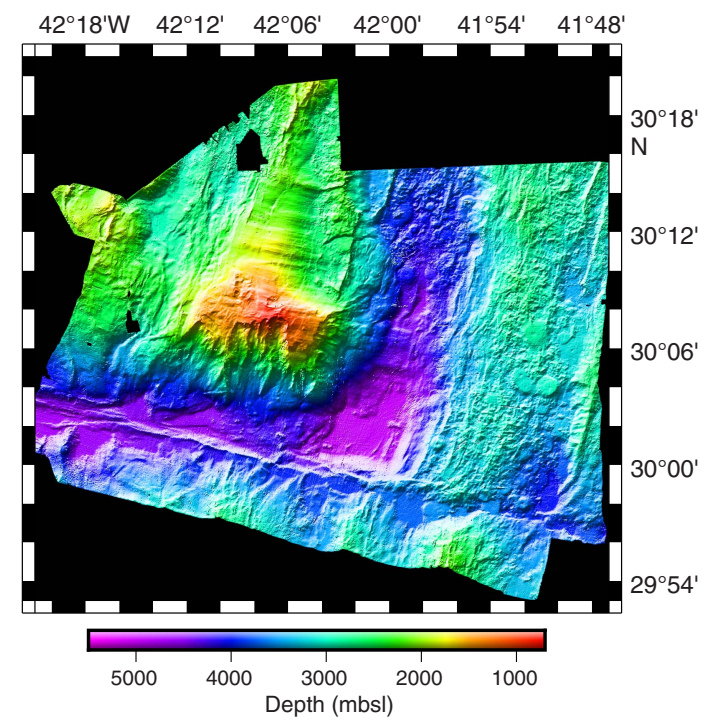


Figure F6. Multibeam bathymetry of Atlantis Massif acquired at $50 \mathrm{~m}$ per pixel resolution (top left), corresponding slope map (top right), and structural and morphological interpretation (bottom).

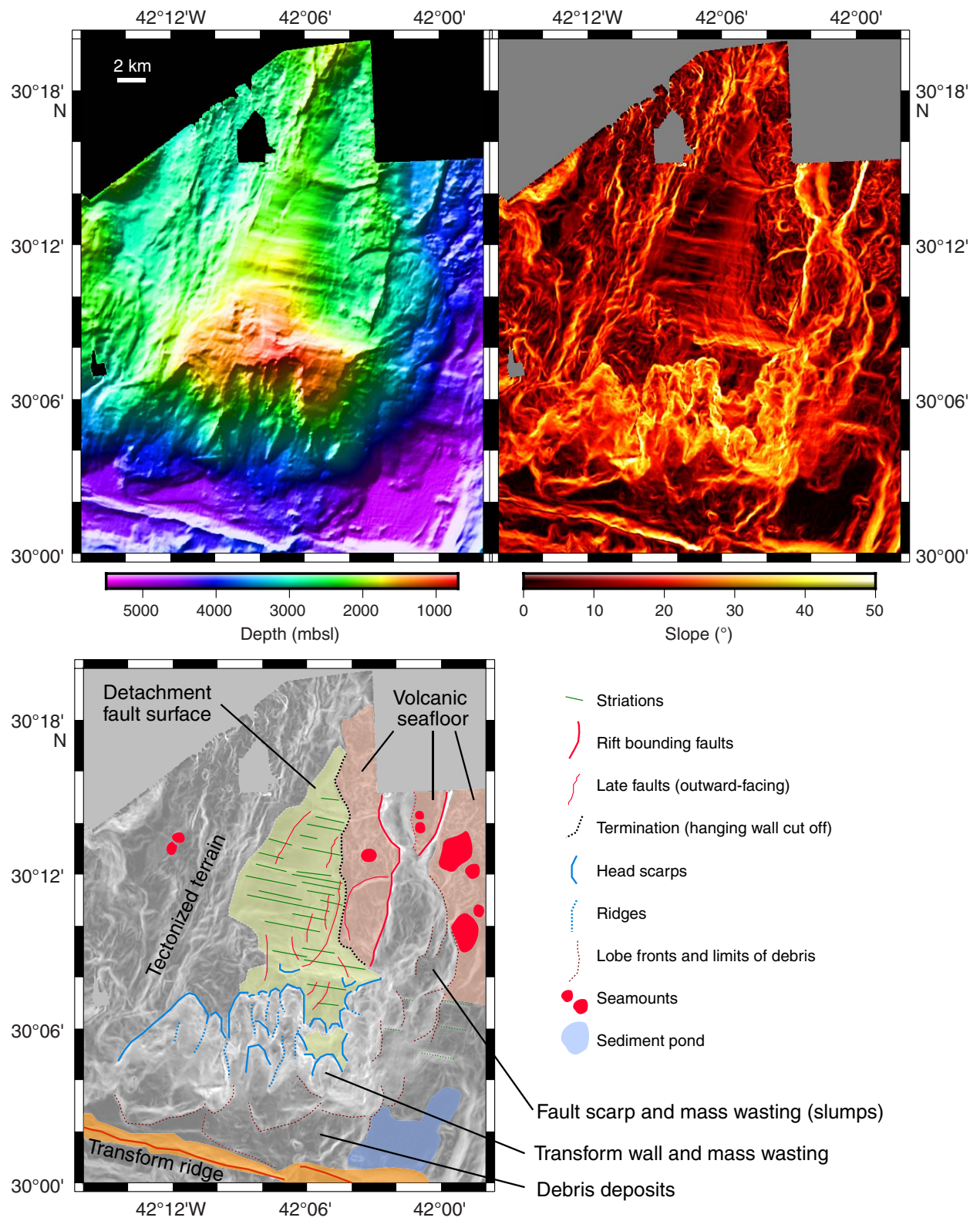

nic cones and a bathymetric texture typical of volcanic terrain along the rift valley floor (Figure F7). This portion of volcanic seafloor is bounded further east by a fault scarp, corresponding to the top of a backtilted tectonic block, as previously identified (Blackman et al., 2002; Cann et al., 1997).

The termination is not preserved to the south, ridgeward of the elevated portion of the detachment. Instead, the striated surface is dissected by a major scarp, with a relief of up to $3000 \mathrm{~m}$ from the rift valley floor and the top of the scarp (Figures F6, F7). This scarp shows a lobate structure indicating mass-wasting processes (slumping). Laterally, it links north with the fault scarp bounding the tectonically uplifted volcanic seafloor.

The striated surface is also affected by extensive mass wasting along its southern boundary toward the transform valley (Figures
F6, F7). The mass wasting produces scarps that are concave at their subvertical headwall. The transform wall south of Atlantis Massif has an average slope of $\sim 20^{\circ}$ and numerous channels bounded by high ridges channeling debris that deposits at the base of the transform valley. Smaller scale mass wasting is also observed on steeper slopes of the detachment fault surface, defining the extension-parallel striations.

Late small-slip faults (centimeters to tens of meters) cut the striated detachment surface. Faults are subparallel to oblique to the ridge axis (Figure F7). Most have scarps facing away from the ridge axis, with scarps up to $\sim 10-20 \mathrm{~m}$ in vertical relief. The scarps have gentle slopes $\left(<20^{\circ}\right)$, likely due to the limited resolution of the multibeam bathymetry that cannot resolve these small-size scarps. 


\section{Lithology, alteration, and structure \\ Mantle to lithospheric processes}

Cores from six sites across the southern wall of Atlantis Massif recovered a variety of ultramafic, mafic, and sedimentary rocks that exhibit a range of alteration styles and extent of alteration and deformation. Of the core recovered, serpentinized harzburgites and serpentinized dunites predominate ( $44 \%$ by length); other major

Figure F7. 3-D terrain model of Atlantis Massif with (top) a lateral view west of its eastern flank, (center) a lateral view of its southern flank showing extensive mass wasting, and (bottom) a northward view of the detachment fault surface showing striations and cross-cutting tectonic structures. Terrain model resolution $=50 \mathrm{~m}$ per pixel (top and center) and $20 \mathrm{~m}$ per pixel (bottom). See Figure $\mathbf{F 6}$ for scale on maps of the area, as scaling in 3-D views is variable owing to perspective.
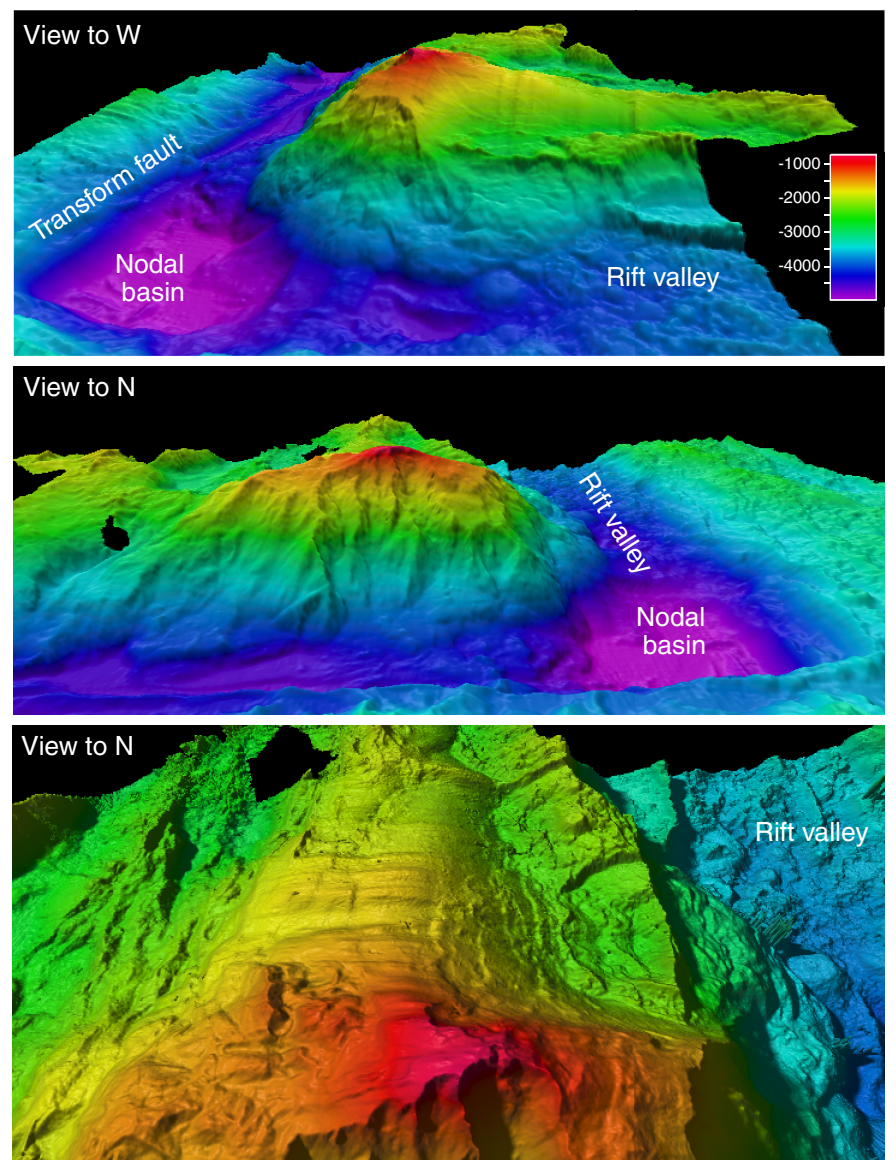

rock types include metadolerites and basaltic rocks (combined 24\%) and schistose metasomatic rocks containing talc, amphibole, and/or chlorite (11\%). Minor calcareous sedimentary units (8\%) and gabbroic rocks (4\%) were also recovered (Figure F9); $9 \%$ of the core length could not be classified into a major rock type.

Serpentinized harzburgites and subordinate serpentinized dunites are typically undeformed and commonly exhibit protogranular textures but are extensively serpentinized. Serpentinized dunites are found exclusively as limited intervals alternating with harzburgite and likely represent relict mantle melt channels. Mantle meltrock reaction textures including vermicular spinels, and orthopyroxene veins were also observed. Minor intervals of ultramafic rocks infiltrated by gabbroic melts are also present. A small volume of gabbroic plutonic rocks was recovered, but no long coherent sections of gabbroic core were observed. Dolerites intrude amphibolerich fault rocks, locally with fractured chilled margins adjacent to these contacts. Poorly vesicular aphanitic to microcrystalline basalts are also present, typically within sedimentary breccias and commonly with glassy margins. Calcareous sands rich in foraminifers and with rare rounded lithic fragments of basalt are common in shallow cores.

The southern wall is characterized by distinctly heterogeneous, both laterally and vertically, distribution of ultramafic and mafic rocks and a strong degree of alteration (Figure F10). The rock types and proportion of gabbroic rocks recovered during Expedition 357 are distinctly different from the $1400 \mathrm{~m}$ long core of gabbroic rocks recovered during Expedition 304/305 at the central dome of the Atlantis Massif.

\section{Lithostratigraphy}

The lithostratigraphy is described in an east-west transect across the southern wall of Atlantis Massif, followed by the sites north of the southern wall, as illustrated in Figure F10.

\section{Eastern sites}

Site M0075. The upper sections of both holes at Site M0075 recovered surficial deposits of angular sedimentary basaltic breccias underlying carbonate sand, with Hole M0075B recovering underlying rubble and drilled fragments of metadolerite in addition to talcamphibole-chlorite-rich intervals.

Site M0068. Site M0068 is structurally more complex than other sites, and a variety of lithologies were recovered, including intervals of intact rock commonly bounded by deformed talc-amphibole schists and breccias. Intervals of serpentinized harzburgite are locally found with small gabbroic veins, and one interval appears to have been extensively impregnated by gabbroic melt. Some fresh ol-

Figure F8. Across-axis profiles over Atlantis Massif and the adjacent rift valley with projected locations of Expedition 357 sites. The southernmost profile (red) runs along the southern sites, the black profile runs over Site M0074, and the blue profile runs close to Hole U1309D, which was drilled to >1500 mbsf.

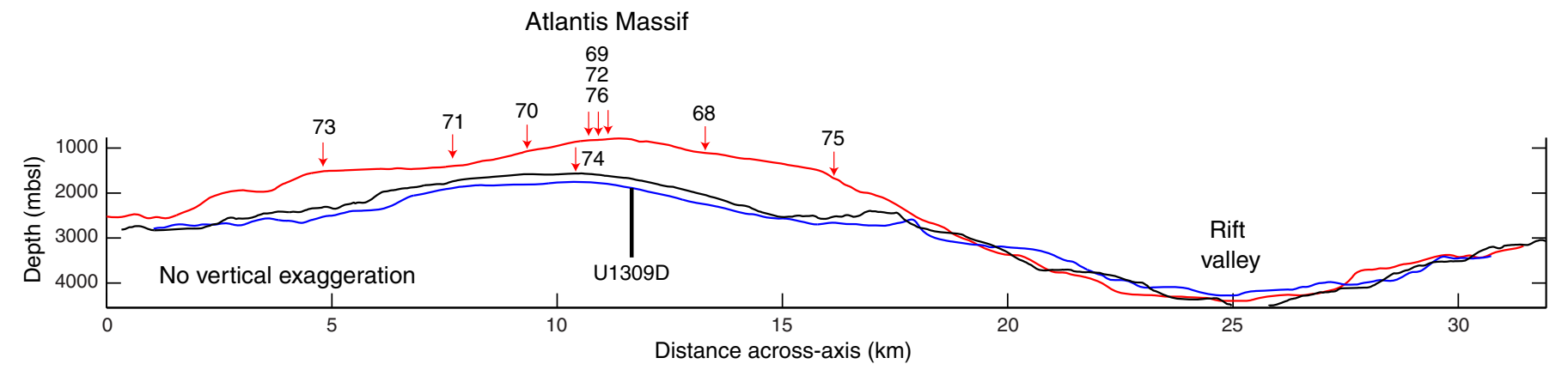


Figure F9. Lithologic variations, Expedition 357. Pie charts show percentages of dominant lithologies recovered from each drilled site based on integrated core length and are plotted against a bathymetry profile of the Atlantis Massif southern wall.

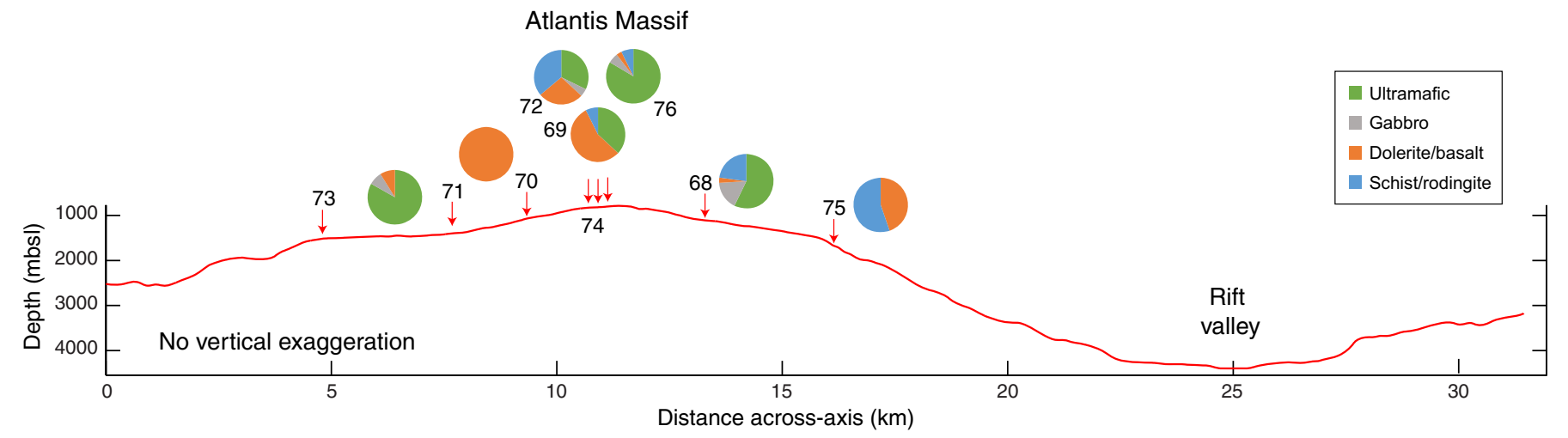

Figure F10. Recovery and described lithology for all sites, Expedition 357.
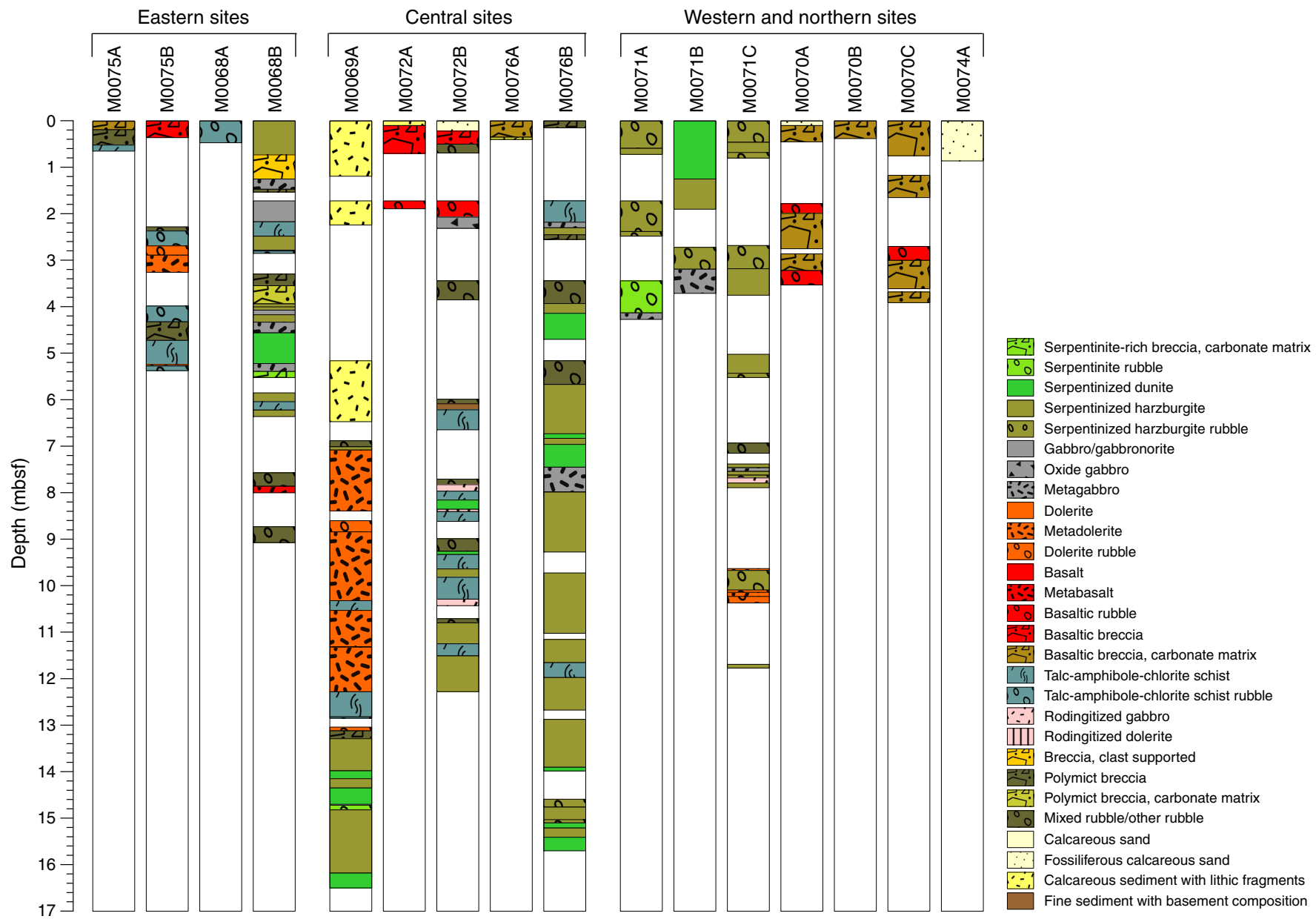

ivine was also observed in the serpentinized harzburgite from this site. Metagabbro and gabbronorite are present in small intervals. Metagabbro and talc-tremolite schists were both observed to contain rare zircon in thin section. Most of the lower cores are composed of loose rubble of mixed composition. Structurally, this site is interpreted as a mass-wasting deposit with large boulders in places separated by intervals of finer rubble.

\section{Central sites}

Site M0069. Hole M0069A consists of 10 cores that recovered serpentinized harzburgites, lesser serpentinized dunites, metagabbros, and metadolerites. The upper four cores of the hole contain carbonate sand, transitioning into a loose rubble unit dominated by angular fragments of serpentinized harzburgite (Section 5R-1, Unit 1; fragments to $4 \mathrm{~cm}$ ). Coherent sections of ser- 
pentinized harzburgites ( $5 \%$ bastite after orthopyroxene) with observable mesh textures were observed below (Section 5R-1, Unit 2). A large portion of the remaining cores is dominated by metadolerite (Sections 5R-1, Unit 3, through 9R-1, Unit 2) and rubble sections. Metadolerite is generally aphyric and microcrystalline to fine grained (typically $0.2-0.5 \mathrm{~mm}$ ); some sections exhibit larger clinopyroxene (up to $1 \mathrm{~mm}$ ) and disseminated sulfides $(<1 \mathrm{~mm})$. The lower sections of the hole (9R-1, Unit 3, through 10R-3) contain alternating serpentinized harzburgites and serpentinized dunites; harzburgites exhibit relict orthopyroxene (bastites; up to $10 \mathrm{~mm}$ and typically with a modal abundance of $10 \%-15 \%)$, and dunites typically contain chromian-spinel.

Site M0072. In contrast to many other sites, Site M0072 contains abundant mafic and metasomatic domains within serpentinized peridotites. The upper sections of both holes consist of surficial features including carbonate sands (with centimeter-scale subrounded basaltic lithic fragments), sedimentary basaltic breccias, and basaltic rubble (with rare oxide gabbro fragments observed in Hole M0072B). Deeper intervals of the basement were drilled in Hole M0072B; below surficial units, rubble sections of mixed composition (metabasalt, metagabbro, and serpentinized harzburgite; Sections 3R-1 through 5R-1, Unit 1) overlie a principally continuous interval of alternating talc-amphibole schists, rodingites, and serpentinized harzburgites (Sections 5R-1, Unit 3, to bottom of hole in 8R-2).

Site M0076. The predominant igneous lithology of Site M0076 is serpentinized porphyroclastic harzburgite with lesser mafic lithologies. The upper sections of both holes are sedimentary basaltic breccias, which are stratigraphically better preserved in Hole M0076A (including the overlying fossiliferous carbonate sediment; Section 357-M0076B-1R-1 contains mostly rubble). Below this uppermost interval is a principally coherent sequence dominated by oxidized serpentinized harzburgites. The upper contact of this zone consists of talc-amphibole schists that enclose small sections of metagabbro and oxidized serpentinized harzburgite. This transition into coherent intervals of metagabbro and oxidized serpentinized harzburgite (bastite after orthopyroxene to $10 \mathrm{~mm}$, typically at a modal abundance of 10\%-15\%; Section 357-M0076A-2R-1, Unit 3). Below sections of mixed rubble (including fragments of serpentinized harzburgite, serpentinized dunite, metagabbro, and talcamphibole schists) with intervals of coherent serpentinites (Sections $3 R-1$ and 4R-1, Unit 1) are continuous sections of veined and altered alternating serpentinized harzburgites and serpentinized dunites (Section 4R-1, Unit 2 and below).

\section{Western and northern sites}

Site M0071. Site M0071 cores consist principally of serpentinized harzburgites and serpentinized dunites, with intervals of metagabbro and evidence for metagabbroic infiltration into ultramafic rocks. Rubble sections are common throughout, and the ultramafic lithologies stratigraphically overlie a drilled interval of metadolerite. Overall, the site appears to have been drilled through a large ultramafic-dominated boulder on top of the surface of Atlantis Massif.

Site M0070. The recovered lithologies are dominated by aphanitic to microcrystalline basalts that are typically poorly to sparsely vesicular and variably altered. Basaltic and doleritic fragments were exclusively observed within a variably cemented carbonate-matrix breccia. The material cored from this site is interpreted to be surficial sedimentary material (although this is likely to be locally derived); no coherent sequences of intact igneous rock were drilled.
Occasional plagioclase-phyric basalt fragments and minor metadolerite were observed.

Site M0074. A single short core of fossiliferous carbonate sand was recovered.

\section{Hydrothermal alteration of mantle-dominated lithosphere at Atlantis Massif}

Alteration types

Within the recovered cores, five types of alteration were distinguished: serpentinization, talc-amphibole-chlorite metasomatism, rodingitization, oxidation, and one type classified as "other." This "other" classification refers to hydration of gabbros, dolerites, and basaltic lithologies. Serpentinization is present throughout the sites and predominantly manifests as pervasive alteration with extensive to complete replacement of the primary mineralogy. Serpentinization is characterized by mesh textures after olivine, bastites after orthopyroxene, and serpentine veins. Talc-amphibole-chlorite metasomatism is evidenced by pale greenish white alteration with assemblages of variable proportions of talc, amphibole, and chlorite. It develops both as pervasive and localized alteration and encloses serpentinized harzburgite intervals on centimeter to decimeter scales. Talc-amphibole-chlorite metasomatism is also found at the contacts with gabbros. Rodingitization is primarily restricted to Site M0072, where approximately five centimeter-sized intervals with pale brown to pinkish color occur adjacent to dark green regions of chlorite black walls and are repeatedly present over a few meters. Oxidation is characterized by reddish to brown serpentinized harzburgites and dunites. It occurs as both pervasive and localized alteration and is also associated with calcium carbonate veining. Hydration of dolerites and basalts manifests as pervasive background alteration with slight to moderate intensity accompanied by alteration halos that flank veins. Secondary minerals vary depending on the temperature of alteration, with dolerites dominated by greenschist facies minerals (chlorite and amphibole) and basalts by low-temperature oxidation to iron oxyhydroxides and clays. Hydration of gabbros is generally associated with chlorite-amphibole assemblages.

\section{Alteration history}

Serpentinization, talc-amphibole-chlorite metasomatism, and oxidation alteration types are always present at sites that recovered ultramafic lithologies. Of these three types, serpentinization is the most dominant and pervasive. Overprinting relationships are frequently observed and demonstrate an overall progression from serpentinization to talc-amphibole-chlorite metasomatism and later oxidation. Rodingites show exceptional relationships between rodingite, talc \pm amphibole-rich zones, and serpentinized harzburgites and form at the contacts between gabbroic veins/lenses and serpentinized harzburgites.

Hydrothermal veins are present within all lithologies, and compositions include serpentine, talc, chlorite, amphibole, epidote, quartz, and calcium carbonate. The veins are often complex, with multiple infillings and internal textures. Crosscutting relationships are complicated, with the same veins observed both crosscutting and being crosscut by a second vein. These observations indicate that the hydrothermal system does not show a simple evolution of the fluids. The cores contained a surprisingly low abundance and density of calcium carbonate veins, even in the sites around the LCHF.

Based on these observations, it is clear that hydrothermal alteration at Atlantis Massif is a highly dynamic system with complex re- 
lationships between the three dominant alteration types. The heterogeneity of the alteration and the hydrothermal veins provide insight into the scales of the hydrothermal processes operating within the shallow detachment fault zone.

\section{Structures and deformation history}

The drilled sites are located along a roughly spreading-parallel transect (west-east) in various positions (trough or wall/flank) relative to individual corrugations of the detachment fault over the southern wall of Atlantis Massif. Despite the fact that a number of the holes recovered rocks that are considered not to be in situ, generalizations can be made about the structural history recorded.

Rare magmatic fabrics characterized by diffuse but planar centimeter-scale banding/layering of igneous minerals in gabbroic rocks were recovered in Hole M0068. Where characterized, the majority of the recovered harzburgite preserves protogranular textures; only rare, low intensity, localized protoclastic serpentinized peridotites were recovered.

As in Hole U1309D, a minimal amount of recovered core has strongly deformed microstructures formed at high temperatures. The majority of the recovered cores show only greenschist-grade semibrittle and brittle deformation, commonly associated with doleritic intrusions. Fault rocks in shear zones are dominated by anastomosing intervals of variable intensity, with schistose amphibole \pm talc \pm chlorite zones up to tens of centimeters thick. Locally, schistose shear zones contain undeformed dolerite intrusions with preserved chilled margins; elsewhere, dolerite sheets record brittle and semibrittle deformation textures indicating repeated magmatism and faulting. Thin intervals of the schistose shear zones locally display intense cataclasis of other rock types reworked in the fault zone, with rare fine-grained intervals of cataclasis (possible fault gouge) recovered.

\section{Bulk rock geochemistry}

The compositional ranges in major and trace elements measured in the 19 bulk rock samples reflect lithology differences as well as the type and intensity of alteration (Table T4; see Table T5 in the Eastern sites chapter [Früh-Green et al., 2017b]). The sum of measured major elements varies from 85.7 to $101.2 \mathrm{wt} \%$, due to heterogeneous degrees of alteration and water incorporation. Trace element abundances are generally in the parts to subparts per million range, with the exception of high $\mathrm{Ni}$ and $\mathrm{Cr}$ concentrations in the ultramafic lithologies.

Independent of the site location, altered ultramafic lithologies and talc-amphibole-chlorite schists form two groups within the $\mathrm{SiO}_{2}-\mathrm{MgO}$ space (Figure F11; see Table T5 in the Eastern sites chapter [Früh-Green et al., 2017b]). Talc-amphibole-chlorite schists are associated with the highest $\mathrm{SiO}_{2} / \mathrm{MgO}$ ratios $\left(\mathrm{SiO}_{2}>55.1 \mathrm{wt} \%\right.$ [normalized concentrations] and $\mathrm{MgO}<28.9 \mathrm{wt} \%$ ), whereas the serpentinized ultramafic rocks are associated with the lowest ratios $\left(\mathrm{SiO}_{2}<49.3\right.$ and $\left.\mathrm{MgO}>37.6 \mathrm{wt} \%\right)$. A trend is identifiable within this second group, with impregnated/metasomatized samples exhibiting the highest $\mathrm{SiO}_{2} / \mathrm{MgO}$ ratios and the serpentinized dunites the lowest. This reflects, on one hand, the crystallization of talc and presence of pyroxenes and, on the other hand, the lack of pyroxenes. Overall, talc-amphibole-chlorite schists (and to a certain extent impregnated/metasomatized ultramafic rocks) appear richer in $\mathrm{Al}_{2} \mathrm{O}_{3}$, $\mathrm{Na}_{2} \mathrm{O}, \mathrm{CaO}$, and $\mathrm{TiO}$ and depleted in $\mathrm{Fe}_{2} \mathrm{O}_{3}$. Samples from Hole M0068B exhibit the highest $\mathrm{SiO}_{2}, \mathrm{CaO}$, and $\mathrm{Na}_{2} \mathrm{O}$ contents but the lowest $\mathrm{Al}_{2} \mathrm{O}_{3}$ and $\mathrm{FeO}$ contents. Mafic samples (gabbros and dolerite) also divide in two groups (Figure F12; see Table T5 in the East- ern sites chapter [Früh-Green et al., 2017b]). In this case, the division relates to the degree of hydration and type of alteration (LOI of 0.4, 0.3, $3.3 \mathrm{wt} \%$ for the samples from Hole M0068B as opposed to LOI around $8 \mathrm{wt} \%$ for samples from the central and western sites).

Rare earth element (REE) patterns group by lithology (see Figure F21 in the Eastern sites chapter, Figure F23 in the Central sites chapter, and Figure F10 in the Western sites chapter [Früh-Green et al., 2017b, 2017a, 2017e]). Serpentinized ultramafic rocks have relatively flat to slightly light rare earth element (LREE) depleted chondrite-normalized patterns (typically centered around 1 or below). The impregnated/metasomatized samples from Hole M0072B exhibit values slightly higher than 1 . Dolerites and gabbros exhibit moderate LREE depletions, and values range between 1 and 10. Two of the talc-amphibole-chlorite schists have REE patterns resembling the impregnated/metasomatized samples, whereas another sample (357-M0068A-1R-1, 34-35 cm) reaches normalized values around 50. Finally, positive and negative europium anomalies were observed but do not correlate with a particular lithology or site.

Primitive mantle (PM)-normalized patterns are relatively smooth (see Figure F21 in the Eastern sites chapter, Figure F24 in the Central sites chapter, and Figure F10 in the Western sites chapter [Früh-Green et al., 2017b, 2017a, 2017e]). Along with correlated $\mathrm{Mg \#}$ and Ni abundances (Figure F13), other geochemical trends in serpentinized ultramafic rocks can be identified, including a common uranium positive anomaly (the intensity of which decreases in impregnated/metasomatized samples) (Figure F14), enriched lithium, cerium, and strontium anomalies in the central sites (Table T4). Such anomalies are commonly related to alteration processes, either from hydrothermal alteration or from late interaction with seawater on the seafloor.

\section{Fluid chemistry}

Inorganic, organic, and volatile fluid chemistry

An extensive water sampling program was conducted as part of the expedition to assess geochemical processes in the subsurface and connectivity to bottom water in the form of hydrothermal plumes. Sensor package Niskins were used to collect fluids flushed from the borehole (Table T5), and pore water in sediments were collected where available. An extensive CTD program collected near-bottom water ( $<3 \mathrm{~m}$ above seafloor) from each drill site prior to drilling to identify the undisturbed predrilling characteristics of the area (Table T6). Two casts collected background seawater for comparison in the Atlantis Fracture Zone and the MAR (described as Holes M0075X and M0075Z, respectively, in Table T6). A final cast collected samples from the middle of the hydrothermal plume above the western end of the LCHF by using the methane sensor to identify the appropriate water column depth (described as Hole M0072X in Table T6).

A total of 41 fluid samples were analyzed for shipboard salinity and ammonium, and 38 samples were analyzed for dissolved inorganic chemistry. These samples originated from the sensor package Niskin bottles collected after drilling $(N=14)$, the CTD rosette Niskin bottles collected from bottom water prior to drilling $(N=17)$, and pore water from a few sediment cores collected during drilling $(N=9)$.

Unexpected values were obtained from shipboard measurements of $\mathrm{pH}$ and alkalinity, which prompted reanalysis of alkalinity during the onshore phase of the expedition (see Fluid inorganic chemistry analyses in the Expedition 357 methods chapter [FrühGreen et al., 2017c]). Because $\mathrm{pH}$ must be measured immediately 
Table T4. Chemical compositions of representative lithologies, Sites M0068, M0069, M0071, M0072, M0075, and M0076. Major elements were measured by ICP-OES, and trace elements were measured by high-resolution inductively coupled plasma-mass spectrometry (HR-ICP-MS) using a Thermo Finnigan Element2 ICP-MS. LOI = Loss on Ignition. Mg\# = Mg/(Mg $+\mathrm{Fe}) \times 100$. (Continued on next page.) Download table in .csv format.

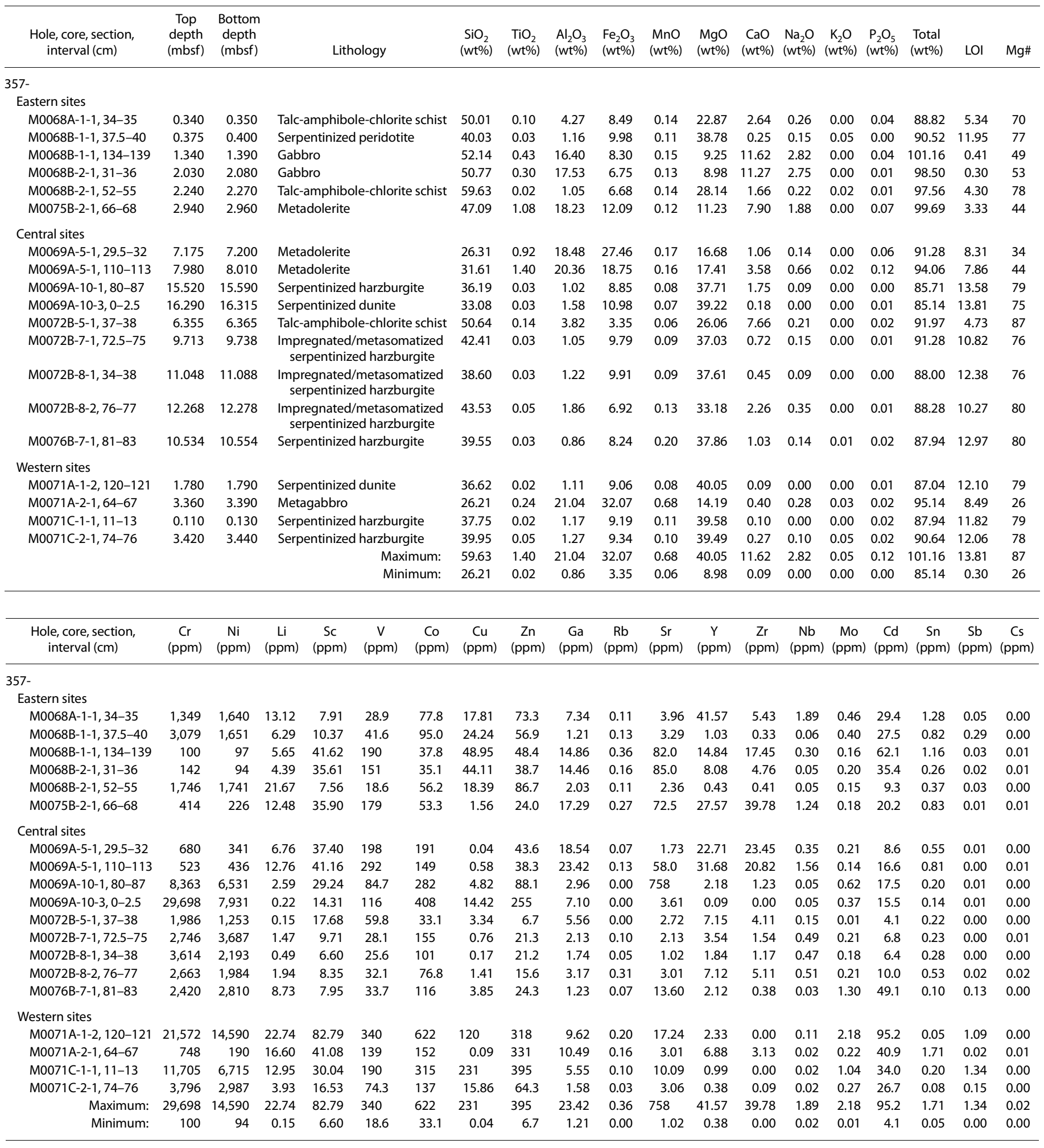


Table T4 (continued).

\begin{tabular}{|c|c|c|c|c|c|c|c|c|c|c|c|c|c|c|c|c|c|c|c|c|c|}
\hline $\begin{array}{l}\text { Hole, core, section, } \\
\text { interval }(\mathrm{cm})\end{array}$ & $\begin{array}{c}\mathrm{Ba} \\
(\mathrm{ppm})\end{array}$ & $\begin{array}{l}\text { La } \\
(\mathrm{ppm})\end{array}$ & $\begin{array}{c}\mathrm{Ce} \\
(\mathrm{ppm})\end{array}$ & $\begin{array}{c}\operatorname{Pr} \\
(\mathrm{ppm})\end{array}$ & $\begin{array}{l}\mathrm{Nd} \\
(\mathrm{ppm})\end{array}$ & $\begin{array}{c}\mathrm{Sm} \\
(\mathrm{ppm})\end{array}$ & $\begin{array}{c}\text { Eu } \\
(\mathrm{ppm})\end{array}$ & $\begin{array}{c}\mathrm{Gd} \\
(\mathrm{ppm})\end{array}$ & $\begin{array}{c}\mathrm{Tb} \\
(\mathrm{ppm})\end{array}$ & $\begin{array}{c}\text { Dy } \\
\text { (ppm) }\end{array}$ & $\begin{array}{c}\text { Ho } \\
\text { (ppm) }\end{array}$ & $\begin{array}{c}\text { Er } \\
(\mathrm{ppm})\end{array}$ & $\begin{array}{c}\mathrm{Tm} \\
(\mathrm{ppm})\end{array}$ & $\begin{array}{c}\mathrm{Yb} \\
(\mathrm{ppm})\end{array}$ & $\begin{array}{c}\mathrm{Lu} \\
(\mathrm{ppm})\end{array}$ & $\begin{array}{c}\mathrm{Hf} \\
(\mathrm{ppm})\end{array}$ & $\begin{array}{c}\mathrm{Ta} \\
(\mathrm{ppm})\end{array}$ & $\begin{array}{c}\text { W } \\
(\mathrm{ppm})\end{array}$ & $\begin{array}{c}\mathrm{Pb} \\
(\mathrm{ppm})\end{array}$ & $\begin{array}{l}\text { Th } \\
(\mathrm{ppm})\end{array}$ & $\underset{(\mathrm{ppm})}{U}$ \\
\hline \multicolumn{22}{|l|}{ 357- } \\
\hline \multicolumn{22}{|l|}{ Eastern sites } \\
\hline M0068A-1-1, 34-35 & 0.87 & 8.56 & 30.19 & 3.64 & 16.89 & 4.43 & 0.52 & 4.86 & 0.91 & 5.86 & 1.29 & 4.11 & 0.65 & 4.29 & 0.65 & 0.38 & 0.18 & 0.07 & 0.35 & 0.75 & 0.09 \\
\hline M0068B-1-1, 37.5-40 & 0.88 & 0.30 & 1.32 & 0.14 & 0.61 & 0.16 & 0.25 & 0.17 & 0.03 & 0.21 & 0.05 & 0.16 & 0.03 & 0.18 & 0.03 & 0.02 & 0.01 & 0.05 & 0.25 & 0.03 & 0.47 \\
\hline M0068B-1-1, 134-139 & 4.41 & 0.92 & 3.29 & 0.55 & 3.21 & 1.28 & 0.63 & 1.72 & 0.37 & 2.52 & 0.55 & 1.68 & 0.26 & 1.59 & 0.24 & 0.69 & 0.02 & 1.05 & 0.40 & 0.05 & 0.04 \\
\hline M0068B-2-1, 31-36 & 2.15 & 0.26 & 0.84 & 0.16 & 1.15 & 0.58 & 0.45 & 0.86 & 0.20 & 1.40 & 0.32 & 1.02 & 0.15 & 0.98 & 0.15 & 0.24 & 0.00 & 0.16 & 0.13 & 0.01 & 0.01 \\
\hline M0068B-2-1, 52-55 & 0.23 & 0.09 & 0.28 & 0.03 & 0.15 & 0.04 & 0.04 & 0.05 & 0.01 & 0.07 & 0.02 & 0.06 & 0.01 & 0.07 & 0.01 & 0.01 & 0.00 & 0.11 & 17 & 0.01 & 0.06 \\
\hline M0075B-2-1, 66-68 & 2.32 & 1.55 & 5.82 & 1.04 & 6.44 & 2.53 & 0.95 & 3.23 & 0.68 & 4.63 & 0.99 & 2.93 & 0.44 & 2.68 & 0.40 & 1.48 & 0.09 & 0.24 & 0.00 & 0.05 & 0.02 \\
\hline \multicolumn{22}{|l|}{ Central sites } \\
\hline M0069A-5-1, 2 & .20 & 0.85 & 2.69 & 0.55 & 3.81 & 1.92 & 0.24 & 2.57 & 0.57 & 3.85 & 0.82 & 2.44 & 0.35 & 2.14 & 0.28 & 0.86 & 0.03 & 0.06 & 0.04 & 0.02 & 0.02 \\
\hline M0069A-5-1, 110-113 & 1.33 & 3.05 & 10.48 & 1.59 & 9.26 & 3.33 & 0.96 & 4.09 & 0.80 & 5.13 & 1.08 & 3.17 & 0.45 & 2.76 & 0.40 & 0.87 & 0.10 & 0.04 & 0.09 & 0.06 & 0.06 \\
\hline M0069A-10-1, 80-87 & 0.72 & 0.23 & 0.74 & 0.11 & 0.60 & 0.17 & 0.11 & 0.23 & 0.05 & 0.35 & 0.08 & 0.25 & 0.04 & 0.29 & 0.05 & 0.03 & 0.01 & 0.07 & 0.12 & 0.01 & 2.22 \\
\hline M0069A-10-3, 0-2.5 & 0.00 & 0.00 & 0.02 & 0.00 & 0.03 & 0.01 & 0.01 & 0.00 & 0.00 & 0.00 & 0.00 & 0.00 & 0.00 & 0.02 & 0.01 & 0.00 & 0.00 & 0.03 & 0.22 & 0.00 & 4.50 \\
\hline M0072B-5-1, 37-38 & 0.00 & 0.21 & 1.06 & 0.23 & 1.56 & 0.68 & 0.26 & 0.89 & 0.20 & 1.33 & 0.29 & 0.86 & 0.13 & 0.81 & 0.12 & 0.19 & 0.01 & 0.10 & 0.09 & 0.01 & 0.02 \\
\hline M00 & 0.00 & 0.47 & 1.72 & 0.25 & 1.2. & 0.34 & & 0.40 & 0.08 & 0.52 & 0. & 0.39 & 0.07 & 0.47 & 8 & 10 & 0.03 & 0 & 09 & 0.09 & 6 \\
\hline M0072B-8-1, 34-38 & 0.15 & 0.24 & 0.90 & 0.14 & 0.75 & 0.22 & 0.06 & 0.24 & 0.05 & 0.31 & 0.07 & 0.25 & 0.04 & 0.30 & 0.05 & 0.08 & 0.05 & 0.01 & 0.05 & 0.09 & 0.03 \\
\hline M0072B-8-2, 76-77 & 0.16 & 0.57 & 2.33 & 0.40 & 2.20 & 0.72 & 0.19 & 0.85 & 0.17 & 1.17 & 0.27 & 0.85 & 0.15 & 0.97 & 0.16 & 0.29 & 0.04 & 0.02 & 0.19 & 0.09 & 1.19 \\
\hline M0076B-7-1, 81-83 & 4.58 & 0.13 & 0.29 & 0.08 & 0.49 & 0.15 & 0.07 & 0.20 & 0.04 & 0.27 & 0.07 & 0.20 & 0.03 & 0.21 & 0.03 & 0.01 & 0.01 & 0.08 & 0.07 & 0.00 & 1.98 \\
\hline \multicolumn{22}{|l|}{ Western sites } \\
\hline M0071A-1-2, 120-121 & 1.19 & 0.16 & 0.33 & 0.06 & 0.40 & 0.17 & 0.10 & 0.33 & 0.05 & 0.36 & 0.09 & 0.29 & 0.06 & 0.46 & 0.09 & 0.00 & 0.00 & 7.62 & 1.91 & 0.00 & 5.05 \\
\hline M0071A-2-1, 64-67 & 0.17 & 0.30 & 0.72 & 0.14 & 1.05 & 0.54 & 0.41 & 0.80 & 0.18 & 1.26 & 0.28 & 0.82 & 0.12 & 0.72 & 0.11 & 0.19 & 0.00 & 0.01 & 0.13 & 0.00 & 0.01 \\
\hline M0071C-1-1, 11-13 & 0.97 & 0.18 & 0.05 & 0.04 & 0.22 & 0.05 & 0.05 & 0.08 & 0.02 & 0.15 & 0.04 & 0.15 & 0.02 & 0.18 & 0.04 & 0.00 & 0.00 & 0.34 & 0.51 & 0.00 & 3.27 \\
\hline M0071C-2-1,74-76 & 0.30 & 0.00 & 0.00 & 0.00 & 0.01 & 0.00 & 0.02 & & & 0.03 & & 0.04 & & 0.07 & 0.02 & 0.00 & 0.01 & 0.02 & 0.57 & 0.00 & 1.52 \\
\hline Maximum: & 4.58 & 8.56 & 30.19 & 3.64 & 16.89 & 4.43 & 0.96 & 4.86 & 0.91 & 5.86 & 1.29 & 4.11 & 0.65 & 4.29 & 0.65 & 1.48 & 0.18 & 7.62 & 1.91 & 0.75 & 5.05 \\
\hline Minimum: & 0.00 & 0.00 & 0.00 & 0.00 & 0.01 & 0.00 & 0.02 & 0.00 & 0.00 & 0.00 & 0.00 & 0.00 & 0.00 & 0.02 & 0.01 & 0.00 & 0.00 & 0.01 & 0.00 & 0.00 & 0.01 \\
\hline
\end{tabular}

after collection, these data unfortunately could not be reproduced. As a substitute for shipboard $\mathrm{pH}$ measurements, values were used from the in situ sensor packages for the period immediately prior to landing the drill on the seafloor and commencing operations (see Water sampling and sensor package data in the Expedition 357 methods chapter (Früh-Green et al., 2017c). These pH values vary from 7.8 to 7.9 and are reported in Table T11 in the Eastern sites chapter (Früh-Green et al., 2017b) as shipboard pH data for bottom water.

With few exceptions, the chemical composition of the fluid samples is identical to seawater composition in terms of salinity, major cations and anions, trace elements (when above limits of detection), and alkalinity, with the noted exception of a slight correlated deviation in sediment alkalinity, dissolved calcium, and the stable carbon isotopic composition of dissolved inorganic carbon in pore water from Hole M0069A sediments. There was no detectable sulfide or ammonia in any sample. A total of 56 and 70 water samples for hydrogen and methane analyses were collected from the shipboard $\mathrm{CTD} /$ rosette system and the drill rig sensor packages, respectively. Both methane and hydrogen range from below detection limit to nanomolar quantities. Typically, samples collected in the sensor package Niskins have significantly higher hydrogen concentrations than the bottom water collected prior to drilling. Hot spots of hydrogen were observed over Sites M0068-M0072; methane concentrations were highest over Site M0072 and were elevated at Sites M0069-M0071.

\section{Microbiology}

To accomplish the microbiology-related objectives of the expedition, an extensive program was carried out offshore to collect whole-round core samples immediately after core retrieval, curation, and scanning with the multisensor core logger to enable preservation of ephemeral microbiological properties. This included
(1) frozen preservation of core material for DNA- and lipid-based analyses in shore-based laboratories, (2) establishment of enrichment incubations on the ship to assess the potential for various microbial metabolisms, (3) collection of samples to evaluate the performance of the tracer delivery, (4) preservation of samples for biomass determination via cell counting, and (5) collection of parallel samples for spatial and isotopic geochemical determination, particularly focused on carbon and minerals. In addition to wholeround core samples, samples of the liner fluids bathing the cores and core barrels were also collected to assess for potential contamination of the samples. Bottom water samples before and after drilling were also collected for this purpose, as well as to examine the flux of subsurface components to the water column.

Execution of the sampling plan for microbiology and other ephemeral properties was highly successful, even given the technological constraints of adapting this methodology to the particulars of seabed drilling. Because of the nature of seabed drilling, individual cores are stored on the seabed in the racks on the drill until all cores from a hole are recovered at once when the drill is recovered to the vessel. During Expedition 357, cores remained on the seabed from $1.5-54 \mathrm{~h}$ prior to recovery on deck, with time on the seabed dependent on drilling speed, total depth of penetration, and position of the core within the hole. The offshore core flow plan was optimized for collecting whole-round cores for ephemeral properties as soon as possible, resulting in total handling times once cores were recovered on deck from $8 \mathrm{~min}$ (for the deepest core sections) to $7 \mathrm{~h}$ (for the shallower sections). In total, 42 whole-round core samples were taken from the 17 holes drilled during the expedition, totaling nearly $8 \mathrm{~m}$ in combined length and representing roughly $14 \%$ of the entire core recovered. From these samples, 29 different enrichment experiments were established on the ship, with initial indications of some positive activity in some of the treatments based on elevated cell counts. 
Figure F11. Whole-rock major elements (normalized, volatile-free, and in oxides) vs. MgO for (impregnated/metasomatized) serpentinized ultramafic rocks and talc-amphibole-chlorite schists from Atlantis Massif. Data from Mid-Atlantic-Ridge abyssal serpentinized peridotites and talc-altered peridotites are presented for comparison. Global abyssal peridotite field defined by data from PetDB (http://www.earthchem.org/petdb, May 2016). Data for talc-altered peridotite field from ODP Leg 209, Hole 1268A (also at PetDB).
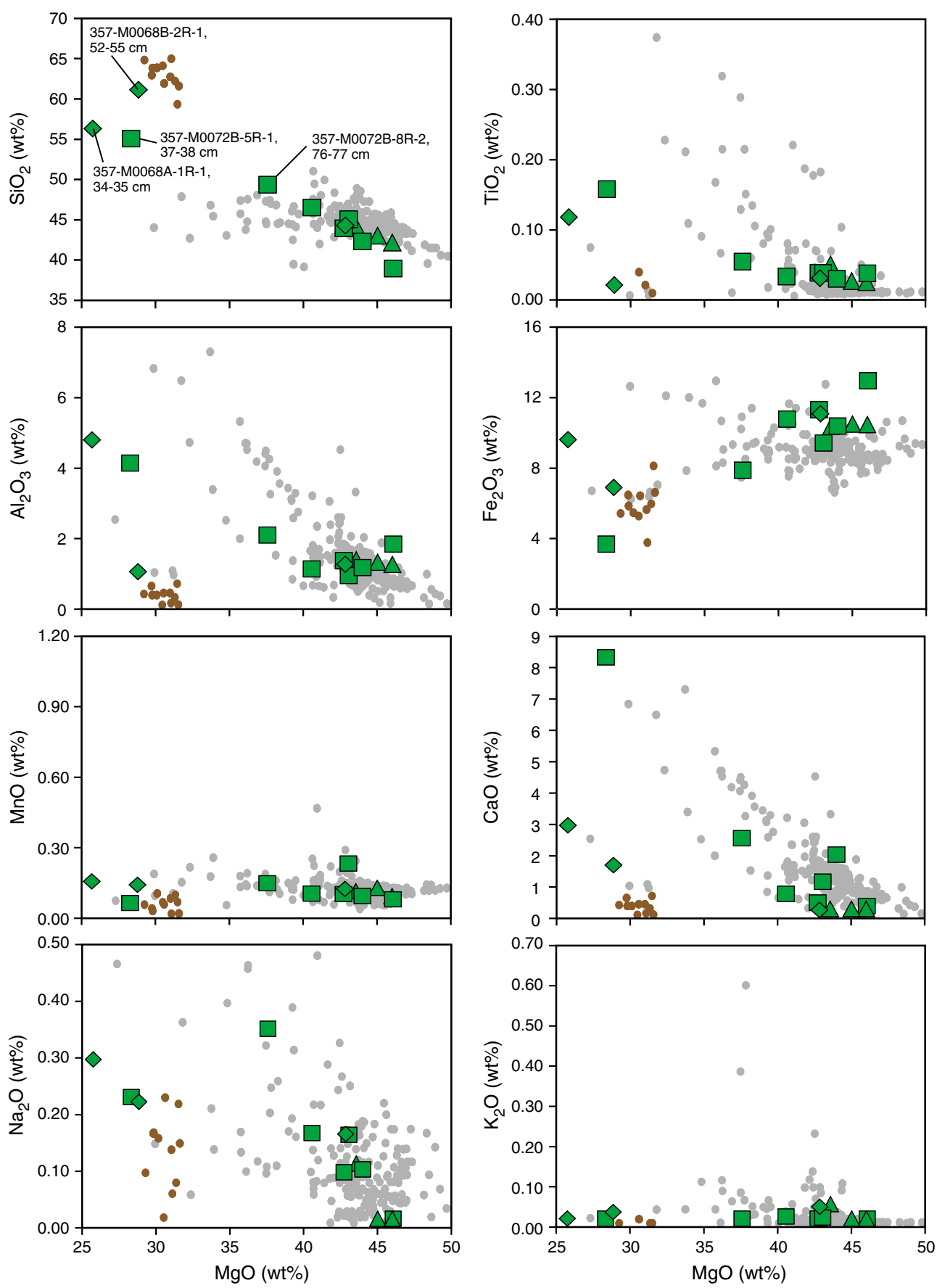

$\triangle$ Eastern ultramafic rocks

$\square$ Central ultramafic rocks

$\Delta$ Western ultramafic rocks

- Mid-Atlantic-Ridge abyssal serpentinized peridotites

Leg 209, Hole 1268A talc-altered peridotites

Subsamples from these whole-round cores were immediately frozen at $-80^{\circ} \mathrm{C}$ and then shipped to the Kochi Core Center. Exteriors of whole-round cores were then cut under sterile conditions with a band saw system equipped in a clean booth and subsampled for perfluoromethylcyclohexane (PFC) tracer checks (exterior) and for postexpedition studies, which include concentration and isotopic composition of total inorganic and total organic carbon, vein analysis, in situ organic carbon and $\mathrm{Fe}$ mineral analysis, and trapped-gas analysis. The interior portions of frozen samples were subsampled and distributed for shore-based DNA and RNA analyses, interior PFC tracers, and amino acid and lipid analyses.

To create initial assessments of microbial biomass in the core samples, cell abundance was determined offshore by direct counting with an epifluorescence microscope following cell separation from the sample matrix. Cell abundance was variable and relatively low, ranging from $10^{2}$ to $10^{4}$ cells $/ \mathrm{cm}^{3}$ in rock samples and higher 
Figure F12. Whole-rock major elements (normalized, volatile-free, and in oxides) vs. MgO for gabbroic and chlorite-rich altered mafic rocks from Atlantis Massif. Data for Mid-Atlantic-Ridge volcanic glass and Expedition 304/305 mafic and ultramafic rocks (Godard et al., 2009) are presented for comparison (http://www.earthchem.org/petdb, May 2016).
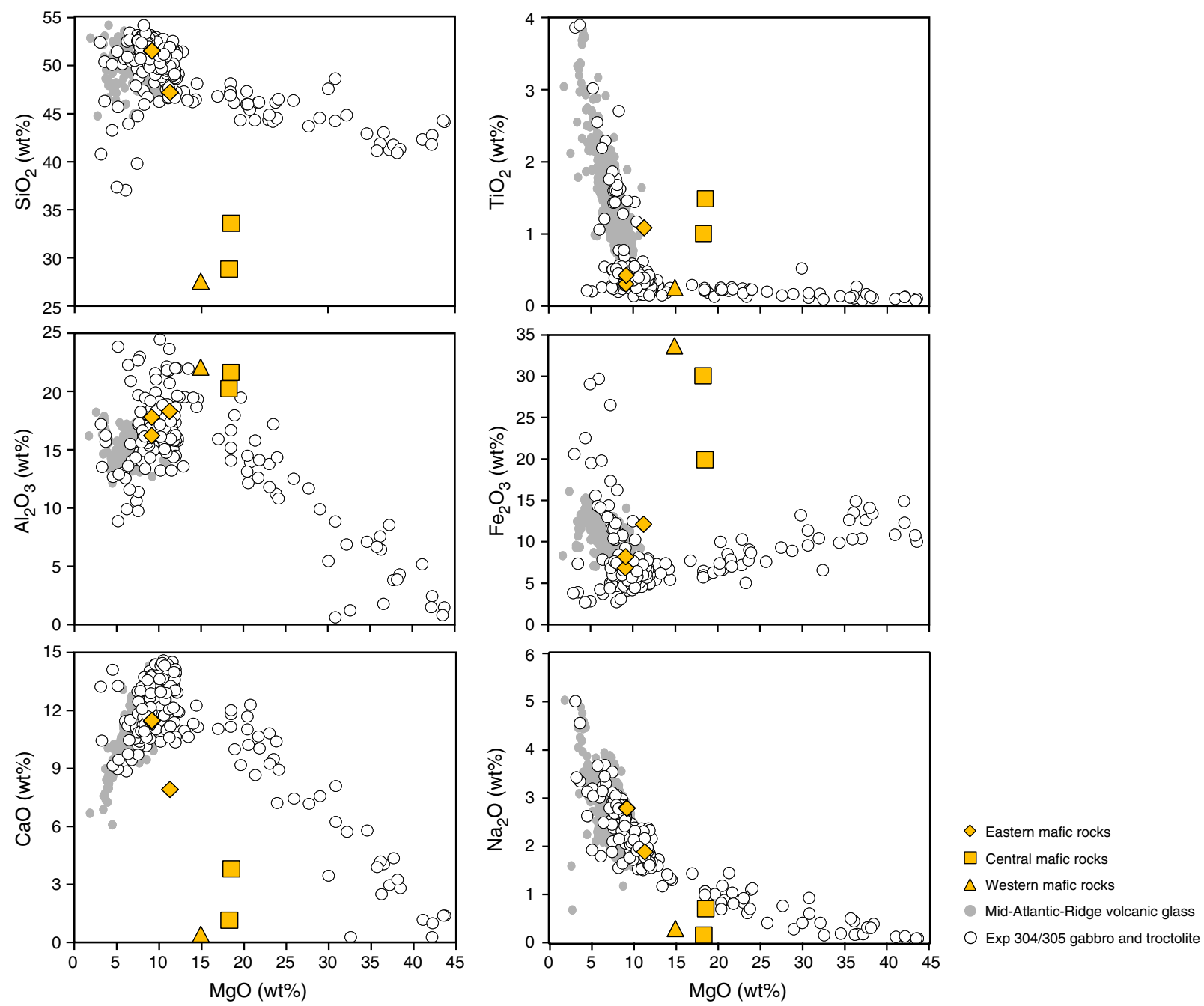

Figure F13. Comparison of $\mathrm{Ni}$ concentrations vs. Mg\# of Atlantis Massif mafic and ultramafic rocks from Expedition 357 with those recovered at Site U1309 during Expedition 304/305 (Godard et al., 2009).

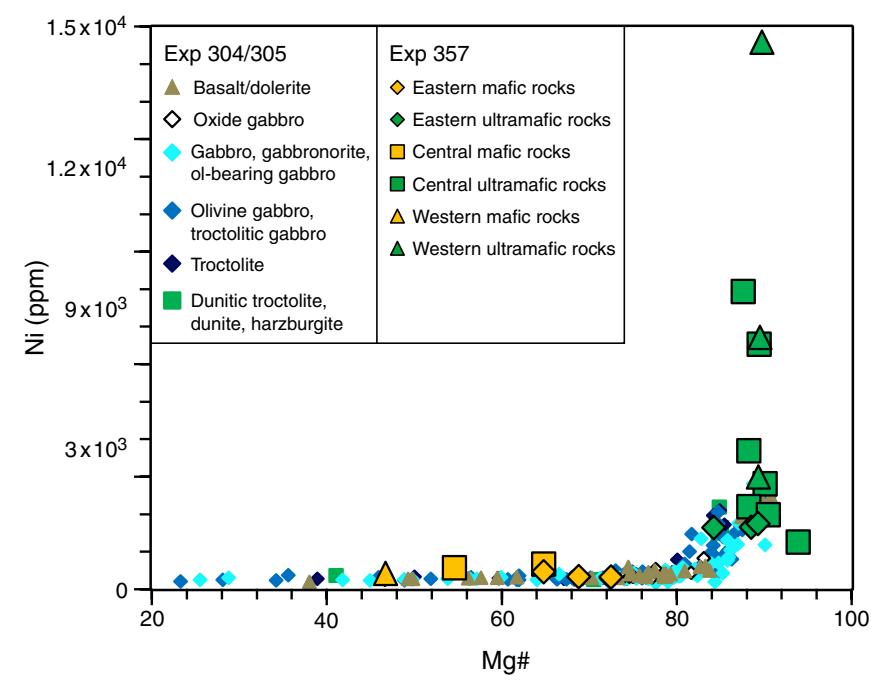

abundances in sediment samples. To enable such low levels of cell detection, great care was taken on the ship to minimize dust contamination of samples during processing, resulting in minimum quantification limit of 48 cells $/ \mathrm{cm}^{3}$.

A major technical development for this expedition was establishing a delivery system for adding a synthetic tracer (PFC) into the drilling fluids to monitor for the possibility of drilling-induced contamination. Samples of core barrel liner fluids, sensor package Niskin bottles, and exterior and interior pieces of whole-round core were collected to quantify the concentration of PFC tracer added during drilling operations and track its potential distribution into samples. After overcoming some initial technical difficulties with the metering pump in the delivery system, we established that PFC was delivered at saturating ( $>1 \mathrm{mg} / \mathrm{L}$ ) concentrations into the drilling fluids. Moreover, appropriate handling conditions combined with coherent core samples resulted in the absence of tracer from the interior of core samples (whereas less coherent materials suffered potential contamination from intrusion of tracer). Tracer delivery was most successful while coring Holes M0068B, M0070AM0070C, M0071C, M0075A, and M0075B. 
Figure F14. Comparison of Rb, $\mathrm{Sr}, \mathrm{U}, \mathrm{Ba}, \mathrm{Pb}, \mathrm{Zr}$, La, and $\mathrm{Yb}$ vs. $\mathrm{Nb}$ and enriched mid-ocean-ridge basalt (E-MORB), normal MORB (N-MORB), PM, and Cl for Atlantis Massif mafic and ultramafic rocks with basalts from global spreading centers, Expedition 357. Data for basalts from global spreading centers (gray dots) from PetDB (http://www.earthchem.org/petdb, May 2016). E-MORB, N-MORB, PM, and Cl data) from Sun and McDonough (1989).
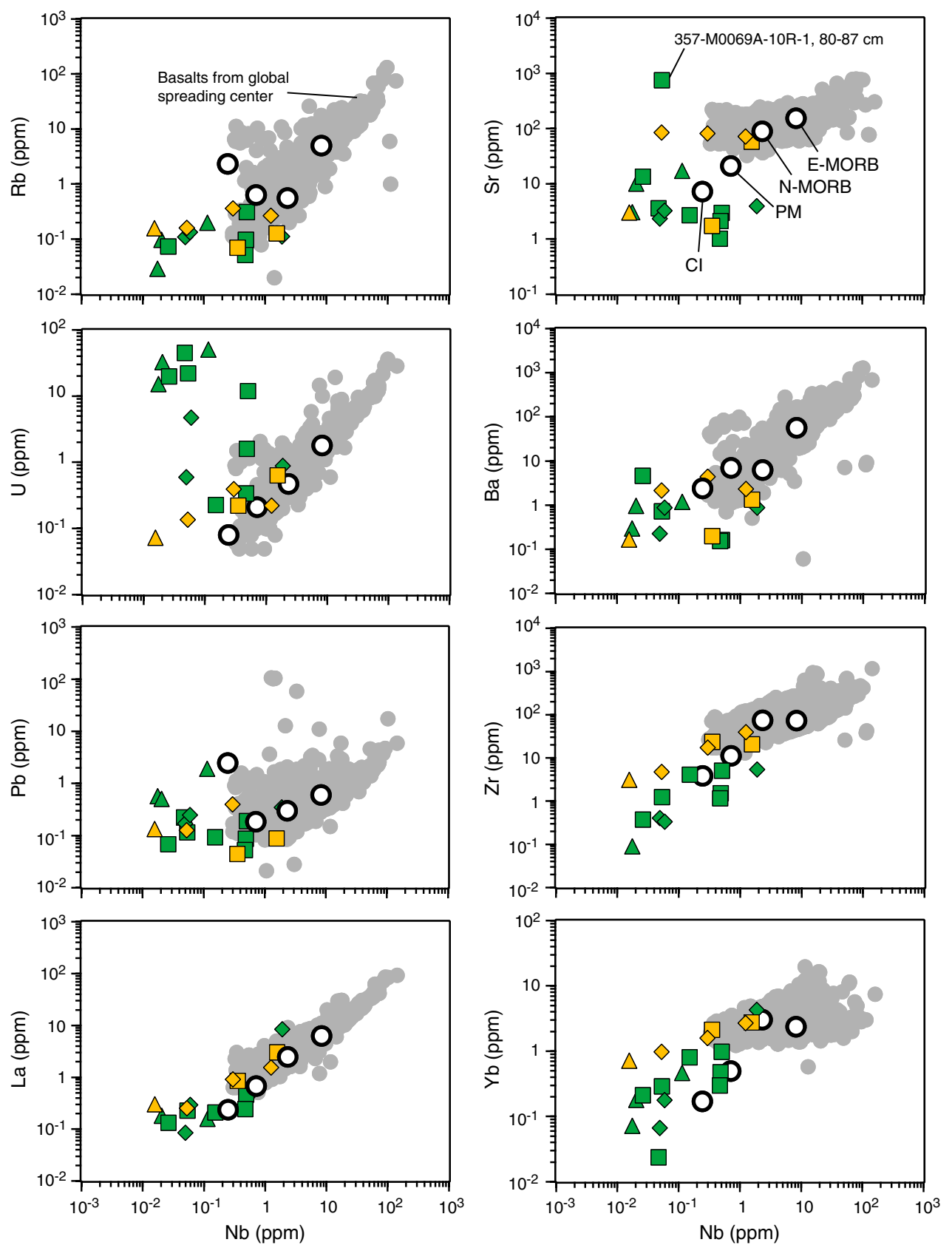

$\diamond$ Eastern mafic rocks
$\diamond$ Eastern ultramafic rocks
$\square$ Central mafic rocks
$\square$ Central ultramafic rocks
$\triangle$ Western mafic rocks
$\Delta$ Western utramafic rocks

\section{Sensor package}

There were 17 full deployments of the custom sensor package on the rock drills during Expedition 357. As described in Offshore operations, each deployment included sensors for dissolved methane, dissolved oxygen, conductivity, temperature, and pressure; deployments shallower than $1200 \mathrm{~m}$ water depth also contained a $\mathrm{pH} / \mathrm{ORP}$ sensor. Data from these sensors were observable in real time during drilling operations. In summary, $\mathrm{pH}$ increased downhole at each site and $\mathrm{CH}_{4}$ background levels were variable, ranging from 0.1 to $58 \mathrm{nM}$, with the highest background values found at eastern Site $\mathrm{M} 0075 . \mathrm{CH}_{4}$ peaks were common during drilling at most sites. The largest excursions in methane concentration during operations were observed in Holes M0070A, M0071A, M0072B, and $\mathrm{M} 0076 \mathrm{~B}$, with visual observation of bubbles emanating from the boreholes during drilling at Holes M0070A, M0071A, and M0071C. ORP minima were very common throughout and were associated with at least two causal mechanisms: (1) specific horizons during continuous drilling of a specific core or (2) the shutting off of flushing water, which reduced the dilution of formation fluid as core barrels were changed. Temperature was variable (typically by a few tenths of a degree but up to $1^{\circ} \mathrm{C}$ at some sites) but difficult to interpret due to the potential for heating by the drill. Background $\mathrm{pH}$ val- 
Table T5. Sensor package (SP) Niskin bottles sampled for fluid chemistry, gas chemistry, and microbiology, Expedition 357 . RD2 Niskins 1 and 2 were connected to tubing and fed water via a pump from close to the breakout table; Niskin 3 was not connected to tubing and was situated approximately $0.8 \mathrm{~m}$ above the seafloor. MeBo Niskins 2 and 3 were connected to the tubing and pump; Niskin 1 was not connected and was situated approximately $1.5 \mathrm{~m}$ above the seafloor. Start and end dates refer to drill deployment and recovery. Niskin trigger times are when the bottles on the sensor package were fired. Times are local (GMT 2h). $\mathrm{COD}=$ closed on deck; bottles triggered but did not fire; water remained in the two Niskins connected to the pump; Niskins were capped $\sim 40$ min after arrival on deck (Hole M0069A) or immediately upon arrival on deck (Hole M0070B). DNF = did not fire; bottles triggered but did not fire. Download table in .csv format.

\begin{tabular}{|c|c|c|c|c|c|c|c|c|}
\hline $\begin{array}{l}\text { Drill } \\
\text { hole }\end{array}$ & $\begin{array}{l}\text { Rock } \\
\text { drill }\end{array}$ & Device & $\begin{array}{c}\text { Site } \\
\text { depth }(m)\end{array}$ & $\begin{array}{l}\text { Start date } \\
(2015)\end{array}$ & $\begin{array}{c}\text { End date } \\
\text { (2015) }\end{array}$ & $\begin{array}{l}\text { Niskin } \\
\text { trigger time } \\
\text { (h UTC) }\end{array}$ & Latitude & Longitude \\
\hline M0068A & $\mathrm{RD} 2$ & SP Niskin 1, pumped & 1102.7 & $6 \mathrm{Nov}$ & $6 \mathrm{Nov}$ & 0800 & $30^{\circ} 7.49^{\prime} \mathrm{N}$ & $42^{\circ} 5.74^{\prime} \mathrm{W}$ \\
\hline M0068A & $\mathrm{RD} 2$ & SP Niskin 2, pumped & 1102.7 & $6 \mathrm{Nov}$ & $6 \mathrm{Nov}$ & 0800 & $30^{\circ} 7.49^{\prime} \mathrm{N}$ & $42^{\circ} 5.74^{\prime} \mathrm{W}$ \\
\hline M0068B & $\mathrm{RD} 2$ & SP Niskin 1, pumped & 1102.0 & $23 \mathrm{Nov}$ & $25 \mathrm{Nov}$ & 0903 & $30^{\circ} 7.51^{\prime} \mathrm{N}$ & $42^{\circ} 5.75^{\prime} \mathrm{W}$ \\
\hline M0068B & $\mathrm{RD} 2$ & SP Niskin 2, pumped & 1102.0 & $23 \mathrm{Nov}$ & $25 \mathrm{Nov}$ & 0902 & $30^{\circ} 7.51^{\prime} \mathrm{N}$ & $42^{\circ} 5.75^{\prime} \mathrm{W}$ \\
\hline M0068B & $\mathrm{RD} 2$ & SP Niskin 3 , not pumped & 1102.0 & $23 \mathrm{Nov}$ & $25 \mathrm{Nov}$ & 0903 & $30^{\circ} 7.51^{\prime} \mathrm{N}$ & $42^{\circ} 5.75^{\prime} \mathrm{W}$ \\
\hline M0069A & RD2 & SP Niskin 1, pumped & 850.9 & $6 \mathrm{Nov}$ & $8 \mathrm{Nov}$ & COD & $30^{\circ} 7.94^{\prime} \mathrm{N}$ & $42^{\circ} 7.20^{\prime} \mathrm{W}$ \\
\hline M0069A & $\mathrm{RD} 2$ & SP Niskin 2, pumped & 850.9 & $6 \mathrm{Nov}$ & $8 \mathrm{Nov}$ & COD & $30^{\circ} 7.94^{\prime} \mathrm{N}$ & $42^{\circ} 7.20^{\prime} \mathrm{W}$ \\
\hline M0070A & MeBo & SP Niskin 1, not pumped & 1140.5 & $8 \mathrm{Nov}$ & 9 Nov & 0245 & $30^{\circ} 8.55^{\prime} \mathrm{N}$ & $42^{\circ} 8.19^{\prime} \mathrm{W}$ \\
\hline M0070A & MeBo & SP Niskin 2, pumped & 1140.5 & $8 \mathrm{Nov}$ & 9 Nov & 0245 & $30^{\circ} 8.55^{\prime} \mathrm{N}$ & $42^{\circ} 8.19^{\prime} \mathrm{W}$ \\
\hline M0070A & MeBo & SP Niskin 3, pumped & 1140.5 & $8 \mathrm{Nov}$ & $9 \mathrm{Nov}$ & 0245 & $30^{\circ} 8.55^{\prime} \mathrm{N}$ & $42^{\circ} 8.19^{\prime} \mathrm{W}$ \\
\hline M0070B & $\mathrm{RD} 2$ & SP Niskin 1, pumped & 1140.5 & $14 \mathrm{Nov}$ & $14 \mathrm{Nov}$ & COD & $30^{\circ} 8.54^{\prime} \mathrm{N}$ & $42^{\circ} 8.16^{\prime} \mathrm{W}$ \\
\hline M0070B & $\mathrm{RD} 2$ & SP Niskin 2, pumped & & & $14 \mathrm{Nov}$ & COD & $30^{\circ} 8.54^{\prime} \mathrm{N}$ & $42^{\circ} 8.16^{\prime} \mathrm{W}$ \\
\hline M0071A & MeBo & SP Niskin 1, not pumped & 1390.8 & 9 Nov & $10 \mathrm{Nov}$ & 0245 & $30^{\circ} 7.71^{\prime} \mathrm{N}$ & $42^{\circ} 9.20^{\prime} \mathrm{W}$ \\
\hline M0071A & MeBo & SP Niskin 2, pumped & 1390.8 & $9 \mathrm{Nov}$ & $10 \mathrm{Nov}$ & 0245 & $30^{\circ} 7.71^{\prime} \mathrm{N}$ & $42^{\circ} 9.20^{\prime} \mathrm{W}$ \\
\hline M0071A & MeBo & SP Niskin 3, pumped & 1390.8 & $9 \mathrm{Nov}$ & $10 \mathrm{Nov}$ & 0245 & $30^{\circ} 7.71^{\prime} \mathrm{N}$ & $42^{\circ} 9.20^{\prime} \mathrm{W}$ \\
\hline M0071B & $\mathrm{RD} 2$ & SP Niskin 1, pumped & 1390.8 & $18 \mathrm{Nov}$ & $19 \mathrm{Nov}$ & 0841 & $30^{\circ} 7.72^{\prime} \mathrm{N}$ & $42^{\circ} 9.19^{\prime} \mathrm{W}$ \\
\hline M0071B & $\mathrm{RD} 2$ & SP Niskin 2, pumped & 1390.8 & $18 \mathrm{Nov}$ & $19 \mathrm{Nov}$ & 0816 & $30^{\circ} 7.72^{\prime} \mathrm{N}$ & $42^{\circ} 9.19^{\prime} \mathrm{W}$ \\
\hline M0071B & $\mathrm{RD} 2$ & SP Niskin 3, not pumped & 1390.8 & $18 \mathrm{Nov}$ & 19 Nov & 0841 & $30^{\circ} 7.72^{\prime} \mathrm{N}$ & $42^{\circ} 9.19^{\prime} \mathrm{W}$ \\
\hline M0071C & MeBo & SP Niskin 1, not pumped & 1390.0 & $25 \mathrm{Nov}$ & $28 \mathrm{Nov}$ & 0050 & $30^{\circ} 7.70^{\prime} \mathrm{N}$ & $42^{\circ} 9.21^{\prime} \mathrm{W}$ \\
\hline M0071C & MeBo & SP Niskin 2, pumped & 1390.0 & $25 \mathrm{Nov}$ & $28 \mathrm{Nov}$ & 0050 & $30^{\circ} 7.70^{\prime} \mathrm{N}$ & $42^{\circ} 9.21^{\prime} \mathrm{W}$ \\
\hline M0071C & MeBo & SP Niskin 3, pumped & 1390.0 & $25 \mathrm{Nov}$ & $28 \mathrm{Nov}$ & 0050 & $30^{\circ} 7.70^{\prime} \mathrm{N}$ & $42^{\circ} 9.21^{\prime} \mathrm{W}$ \\
\hline M0072A & $\mathrm{RD} 2$ & SP Niskin 1, pumped & 820.3 & $10 \mathrm{Nov}$ & $10 \mathrm{Nov}$ & 1503 & $30^{\circ} 7.79^{\prime} \mathrm{N}$ & $42^{\circ} 7.32^{\prime} \mathrm{W}$ \\
\hline M0072A & $\mathrm{RD} 2$ & SP Niskin 2, pumped & 820.3 & $10 \mathrm{Nov}$ & $10 \mathrm{Nov}$ & 1501 & $30^{\circ} 7.79^{\prime} \mathrm{N}$ & $42^{\circ} 7.32^{\prime} \mathrm{W}$ \\
\hline M0072A & $\mathrm{RD} 2$ & SP Niskin 3, not pumped & 820.3 & $10 \mathrm{Nov}$ & $10 \mathrm{Nov}$ & 1503 & $30^{\circ} 7.79^{\prime} \mathrm{N}$ & $42^{\circ} 7.32^{\prime} \mathrm{W}$ \\
\hline M0072B & $\mathrm{RD} 2$ & SP Niskin 1, pumped & 820.3 & $10 \mathrm{Nov}$ & $12 \mathrm{Nov}$ & 0625 & $30^{\circ} 7.79^{\prime} \mathrm{N}$ & $42^{\circ} 7.32^{\prime} \mathrm{W}$ \\
\hline M0072B & RD2 & SP Niskin 2, pumped & 820.3 & $10 \mathrm{Nov}$ & $12 \mathrm{Nov}$ & 0625 & $30^{\circ} 7.79^{\prime} \mathrm{N}$ & $42^{\circ} 7.32^{\prime} \mathrm{W}$ \\
\hline M0072B & $\mathrm{RD} 2$ & SP Niskin 3 , not pumped & 820.3 & $10 \mathrm{Nov}$ & $12 \mathrm{Nov}$ & 0625 & $30^{\circ} 7.79^{\prime} \mathrm{N}$ & $42^{\circ} 7.32^{\prime} \mathrm{W}$ \\
\hline M0073A & MeBo & SP Niskin 1, not pumped & 1430.2 & $15 \mathrm{Nov}$ & $15 \mathrm{Nov}$ & 0630 & $30^{\circ} 7.90^{\prime} \mathrm{N}$ & $42^{\circ} 10.97^{\prime} \mathrm{W}$ \\
\hline M0074A & MeBo & SP Niskin 1, not pumped & 1550.0 & $30 \mathrm{Nov}$ & $30 \mathrm{Nov}$ & 1328 & $30^{\circ} 9.87^{\prime} \mathrm{N}$ & $42^{\circ} 7.32^{\prime} \mathrm{W}$ \\
\hline M0075A & MeBo & No water collected & 1585.6 & $14 \mathrm{Nov}$ & $14 \mathrm{Nov}$ & DNF & $30^{\circ} 7.66^{\prime} \mathrm{N}$ & $42^{\circ} 3.91^{\prime} \mathrm{W}$ \\
\hline M0075A & $\mathrm{RD} 2$ & SP Niskin 1, pumped & 1568.0 & $28 \mathrm{Nov}$ & $29 \mathrm{Nov}$ & 1407 & $30^{\circ} 7.67^{\prime} \mathrm{N}$ & $42^{\circ} 3.98^{\prime} \mathrm{W}$ \\
\hline M0075A & RD2 & SP Niskin 2, pumped & 1568.0 & $28 \mathrm{Nov}$ & $29 \mathrm{Nov}$ & 1406 & $30^{\circ} 7.67^{\prime} \mathrm{N}$ & $42^{\circ} 3.98^{\prime} \mathrm{W}$ \\
\hline M0075A & $\mathrm{RD} 2$ & SP Niskin 3, not pumped & 1568.0 & $28 \mathrm{Nov}$ & $29 \mathrm{Nov}$ & 1406 & $30^{\circ} 7.67^{\prime} \mathrm{N}$ & $42^{\circ} 3.98^{\prime} \mathrm{W}$ \\
\hline M0075B & MeBo & SP Niskin 1, not pumped & 1568.0 & $29 \mathrm{Nov}$ & $30 \mathrm{Nov}$ & 0615 & $30^{\circ} 7.65^{\prime} \mathrm{N}$ & $42^{\circ} 3.97^{\prime} \mathrm{W}$ \\
\hline M0075B & MeBo & SP Niskin 2, pumped & 1568.0 & $29 \mathrm{Nov}$ & $30 \mathrm{Nov}$ & 0614 & $30^{\circ} 7.65^{\prime} \mathrm{N}$ & $42^{\circ} 3.97^{\prime} \mathrm{W}$ \\
\hline M0075B & MeBo & SP Niskin 3, pumped & 1568.0 & $29 \mathrm{Nov}$ & $30 \mathrm{Nov}$ & 0614 & $30^{\circ} 7.65^{\prime} \mathrm{N}$ & $42^{\circ} 3.97^{\prime} \mathrm{W}$ \\
\hline M0076A & $\mathrm{RD} 2$ & No water collected & 768.0 & $15 \mathrm{Nov}$ & $15 \mathrm{Nov}$ & DNF & $30^{\circ} 7.62^{\prime} \mathrm{N}$ & $42^{\circ} 7.08^{\prime} \mathrm{W}$ \\
\hline M0076B & $\mathrm{RD} 2$ & SP Niskin 1, pumped & 768.0 & $15 \mathrm{Nov}$ & $17 \mathrm{Nov}$ & 1531 & $30^{\circ} 7.62^{\prime} \mathrm{N}$ & $42^{\circ} 7.07^{\prime} \mathrm{W}$ \\
\hline M0076B & $\mathrm{RD} 2$ & SP Niskin 2, pumped & 768.0 & $15 \mathrm{Nov}$ & $17 \mathrm{Nov}$ & 1243 & $30^{\circ} 7.62^{\prime} \mathrm{N}$ & $42^{\circ} 7.07^{\prime} \mathrm{W}$ \\
\hline M0076B & $\mathrm{RD} 2$ & SP Niskin 3 , not pumped & 768.0 & $15 \mathrm{Nov}$ & $17 \mathrm{Nov}$ & 1531 & $30^{\circ} 7.62^{\prime} \mathrm{N}$ & $42^{\circ} 7.07^{\prime} \mathrm{W}$ \\
\hline
\end{tabular}

ues were on the order of 7.8 , and ORP values were about $340 \mathrm{mV}$. Background temperatures were variable with depth and ranged from $5^{\circ}$ to $10^{\circ} \mathrm{C}$.

\section{Borehole plugs}

Two borehole plug systems were successfully installed by the RD2 drill (Holes M0072B and M0075B), with two other attempts made (Holes M0068B and M0071B) with unknown success. These borehole plug systems will enable future sampling of formation fluid from the boreholes to understand geochemical and microbiological processes in an actively serpentinizing system. In addition, equipment was left behind in three holes (Holes M0069A, M0071C, and $\mathrm{M} 0076 \mathrm{~B}$ ) after difficult drilling conditions; it may be possible to utilize this lost equipment for scientific purposes in the future.

\section{Physical properties}

Physical properties data were acquired from all cores recovered during Expedition 357. This includes measurements on wholeround cores (magnetic susceptibility, gamma density, electrical resistivity, NGR, and digital line scans through liners), split cores 
Table T6. CTD rosette cast locations, depths, and associated drill holes, Expedition 357. Download table in .csv format.

\begin{tabular}{|c|c|c|c|c|c|c|c|c|}
\hline Cast number & Hole & Bottle $(N)$ & $\begin{array}{c}\text { Site } \\
\text { depth }(m)\end{array}$ & $\begin{array}{l}\text { Date } \\
\text { (2015) }\end{array}$ & Latitude & Longitude & $\begin{array}{c}\text { Sample } \\
\text { depth (m) }\end{array}$ & $\begin{array}{l}\text { Altimeter } \\
\text { (m) }\end{array}$ \\
\hline JC130_001 & M0068A & $1,5,9$ & 1001 & $6 \mathrm{Nov}$ & $30^{\circ} 7.51^{\prime} \mathrm{N}$ & $42^{\circ} 5.75^{\prime} \mathrm{W}$ & 1099 & 2.2 \\
\hline JC130_001 & M0068A & 13 & 1001 & $6 \mathrm{Nov}$ & $30^{\circ} 7.95^{\prime} \mathrm{N}$ & $42^{\circ} 5.75^{\prime} \mathrm{W}$ & 763 & \\
\hline JC130_001 & M0068A & 17 & 1001 & $6 \mathrm{Nov}$ & $30^{\circ} 7.95^{\prime} \mathrm{N}$ & $42^{\circ} 5.75^{\prime} \mathrm{W}$ & 385 & \\
\hline JC130_001 & M0068A & 21 & 1001 & $6 \mathrm{Nov}$ & $30^{\circ} 7.95^{\prime} \mathrm{N}$ & $42^{\circ} 5.75^{\prime} \mathrm{W}$ & 8 & \\
\hline JC130_002 & M0069A & $1,5,9$ & 849 & $6 \mathrm{Nov}$ & $30^{\circ} 7.98^{\prime} \mathrm{N}$ & $42^{\circ} 7.22^{\prime} \mathrm{W}$ & 848 & $1.7-3.0$ \\
\hline JC130_002 & M0069A & 13 & 849 & $6 \mathrm{Nov}$ & $30^{\circ} 7.98^{\prime} \mathrm{N}$ & $42^{\circ} 7.22^{\prime} \mathrm{W}$ & 583 & \\
\hline JC130_002 & M0069A & 17 & 849 & $6 \mathrm{Nov}$ & $30^{\circ} 7.98^{\prime} \mathrm{N}$ & $42^{\circ} 7.22^{\prime} \mathrm{W}$ & 293 & \\
\hline JC130_002 & M0069A & 21 & 849 & $6 \mathrm{Nov}$ & $30^{\circ} 7.98^{\prime} \mathrm{N}$ & $42^{\circ} 7.22^{\prime} \mathrm{W}$ & 11 & \\
\hline JC130_003 & M0069A & 1 & 851 & $8 \mathrm{Nov}$ & $30^{\circ} 7.95^{\prime} \mathrm{N}$ & $42^{\circ} 7.20^{\prime} \mathrm{W}$ & 848 & $2.1-2.7$ \\
\hline JC130_003 & M0069A & 9 & 851 & $8 \mathrm{Nov}$ & $30^{\circ} 7.95^{\prime} \mathrm{N}$ & $42^{\circ} 7.20^{\prime} \mathrm{W}$ & 848 & $2.1-2.7$ \\
\hline JC130_003 & M0069A & 13 & 851 & $8 \mathrm{Nov}$ & $30^{\circ} 7.95^{\prime} \mathrm{N}$ & $42^{\circ} 7.20^{\prime} \mathrm{W}$ & 848 & $2.1-2.7$ \\
\hline JC130_004 & M0070A & $1,5,9$ & 1140 & $8 \mathrm{Nov}$ & $30^{\circ} 8.54^{\prime} \mathrm{N}$ & $42^{\circ} 8.20^{\prime} W$ & 1138 & 1.7 \\
\hline JC130_004 & M0070A & 13 & 1140 & $8 \mathrm{Nov}$ & $30^{\circ} 8.54^{\prime} \mathrm{N}$ & $42^{\circ} 8.20^{\prime} \mathrm{W}$ & 760 & \\
\hline JC130_004 & M0070A & 17 & 1140 & $8 \mathrm{Nov}$ & $30^{\circ} 8.54^{\prime} \mathrm{N}$ & $42^{\circ} 8.20^{\prime} \mathrm{W}$ & 380 & \\
\hline JC130_004 & M0070A & 21 & 1140 & $8 \mathrm{Nov}$ & $30^{\circ} 8.54^{\prime} \mathrm{N}$ & $42^{\circ} 8.20^{\prime} \mathrm{W}$ & 5 & \\
\hline JC130_005 & M0071A & $1,5,9$ & 1384 & $9 \mathrm{Nov}$ & $30^{\circ} 7.69^{\prime} \mathrm{N}$ & $42^{\circ} 9.21^{\prime} \mathrm{W}$ & 1387 & 2.2 \\
\hline JC130_005 & M0071A & 13 & 1384 & $9 \mathrm{Nov}$ & $30^{\circ} 7.69^{\prime} \mathrm{N}$ & $42^{\circ} 9.21^{\prime} \mathrm{W}$ & 902 & \\
\hline JC130_005 & M0071A & 17 & 1384 & 9 Nov & $30^{\circ} 7.69^{\prime} \mathrm{N}$ & $42^{\circ} 9.21^{\prime} \mathrm{W}$ & 454 & \\
\hline JC130_005 & M0071A & 21 & 1384 & $9 \mathrm{Nov}$ & $30^{\circ} 7.69^{\prime} \mathrm{N}$ & $42^{\circ} 9.21^{\prime} \mathrm{W}$ & 6 & \\
\hline JC130_006 & M0072A & $1,5,9$ & 826 & $10 \mathrm{Nov}$ & $30^{\circ} 7.79^{\prime} \mathrm{N}$ & $42^{\circ} 7.34^{\prime} \mathrm{W}$ & 818 & $1.8-2.3$ \\
\hline JC130_006 & M0072A & 13 & 826 & $10 \mathrm{Nov}$ & $30^{\circ} 7.79^{\prime} \mathrm{N}$ & $42^{\circ} 7.34^{\prime} \mathrm{W}$ & 482 & \\
\hline JC130_006 & M0072A & 17 & 826 & $10 \mathrm{Nov}$ & $30^{\circ} 7.79^{\prime} \mathrm{N}$ & $42^{\circ} 7.34^{\prime} \mathrm{W}$ & 243 & \\
\hline JC130_006 & M0072A & 21 & 826 & $10 \mathrm{Nov}$ & $30^{\circ} 7.79^{\prime} \mathrm{N}$ & $42^{\circ} 7.34^{\prime} \mathrm{W}$ & 4 & \\
\hline JC130_007 & M0072X & 1 & 4244 & 11 Nov & $30^{\circ} 2.01^{\prime} \mathrm{N}$ & $42^{\circ} 6.94^{\prime} \mathrm{W}$ & 4134 & \\
\hline JC130_007 & M0072X & 5 & 4244 & $11 \mathrm{Nov}$ & $30^{\circ} 2.01^{\prime} \mathrm{N}$ & $42^{\circ} 6.94^{\prime} \mathrm{W}$ & 4135 & \\
\hline JC130_007 & M0072X & 9 & 4244 & $11 \mathrm{Nov}$ & $30^{\circ} 2.01^{\prime} \mathrm{N}$ & $42^{\circ} 6.94^{\prime} \mathrm{W}$ & 1601 & \\
\hline JC130_007 & M0072X & 17 & 4244 & $11 \mathrm{Nov}$ & $30^{\circ} 2.01^{\prime} \mathrm{N}$ & $42^{\circ} 6.94^{\prime} \mathrm{W}$ & 755 & \\
\hline JC130_008 & M0073A & $1,5,9$ & 1432 & $12 \mathrm{Nov}$ & $30^{\circ} 7.87^{\prime} \mathrm{N}$ & $42^{\circ} 10.95^{\prime} \mathrm{W}$ & 1428 & $1.5-1.8$ \\
\hline JC130_008 & M0073A & 13 & 1432 & $12 \mathrm{Nov}$ & $30^{\circ} 7.87^{\prime} \mathrm{N}$ & $42^{\circ} 10.95^{\prime} \mathrm{W}$ & 960 & \\
\hline JC130_008 & M0073A & 17 & 1432 & $12 \mathrm{Nov}$ & $30^{\circ} 7.87^{\prime} \mathrm{N}$ & $42^{\circ} 10.95^{\prime} \mathrm{W}$ & 482 & \\
\hline JC130_008 & M0073A & 21 & 1432 & $12 \mathrm{Nov}$ & $30^{\circ} 7.87^{\prime} \mathrm{N}$ & $42^{\circ} 10.95^{\prime} \mathrm{W}$ & 4 & \\
\hline JC130_009 & M0074A & 1,5 & 1550 & $13 \mathrm{Nov}$ & $30^{\circ} 09.85^{\prime} \mathrm{N}$ & $42^{\circ} 07.29^{\prime} \mathrm{W}$ & 1550 & 1.3 \\
\hline JC130_009 & M0074A & 9 & 1550 & $13 \mathrm{Nov}$ & $30^{\circ} 09.85^{\prime} \mathrm{N}$ & $42^{\circ} 07.29^{\prime} \mathrm{W}$ & 1041 & \\
\hline JC130_009 & M0074A & 13 & 1550 & $13 \mathrm{Nov}$ & $30^{\circ} 09.85^{\prime} \mathrm{N}$ & $42^{\circ} 07.29^{\prime} \mathrm{W}$ & 752 & \\
\hline JC130_009 & M0074A & 17 & 1550 & $13 \mathrm{Nov}$ & $30^{\circ} 09.85^{\prime} \mathrm{N}$ & $42^{\circ} 07.29^{\prime} \mathrm{W}$ & 523 & \\
\hline JC130_009 & M0074A & 21 & 1550 & $13 \mathrm{Nov}$ & $30^{\circ} 09.85^{\prime} \mathrm{N}$ & $42^{\circ} 07.29^{\prime} \mathrm{W}$ & 6 & \\
\hline JC130_010 & M0075A & $1,5,9$ & 1572 & $14 \mathrm{Nov}$ & $30^{\circ} 7.67^{\prime} \mathrm{N}$ & $42^{\circ} 3.91^{\prime} \mathrm{W}$ & 1581 & $2.3-4.5$ \\
\hline JC130_010 & M0075A & 13 & 1572 & $14 \mathrm{Nov}$ & $30^{\circ} 7.67^{\prime} \mathrm{N}$ & $42^{\circ} 3.91^{\prime} \mathrm{W}$ & 1061 & \\
\hline JC130_010 & M0075A & 17 & 1572 & $14 \mathrm{Nov}$ & $30^{\circ} 7.67^{\prime} \mathrm{N}$ & $42^{\circ} 3.91^{\prime} \mathrm{W}$ & 534 & \\
\hline JC130_010 & M0075A & 21 & 1572 & $14 \mathrm{Nov}$ & $30^{\circ} 7.67^{\prime} \mathrm{N}$ & $42^{\circ} 3.91^{\prime} \mathrm{W}$ & 7 & \\
\hline JC130_11 & M0075X & 1,5 & 4217 & $14 \mathrm{Nov}$ & $30^{\circ} 6.49^{\prime} \mathrm{N}$ & $41^{\circ} 59.87^{\prime} \mathrm{W}$ & 4221 & 2.0 \\
\hline JC130_11 & M0075X & 9,13 & 4217 & $14 \mathrm{Nov}$ & $30^{\circ} 6.49^{\prime} \mathrm{N}$ & $41^{\circ} 59.87^{\prime} \mathrm{W}$ & 4124 & \\
\hline JC130_11 & M0075X & 17,21 & 4217 & $14 \mathrm{Nov}$ & $30^{\circ} 6.49^{\prime} \mathrm{N}$ & $41^{\circ} 59.87^{\prime} \mathrm{W}$ & 4023 & \\
\hline JC130_12 & M0075Z & 1,5 & 821 & 1 Dec & $30^{\circ} 7.44^{\prime} \mathrm{N}$ & $42^{\circ} 7.16^{\prime} \mathrm{W}$ & 807 & \\
\hline JC130_12 & M0075Z & 9,13 & 821 & 1 Dec & $30^{\circ} 7.44^{\prime} \mathrm{N}$ & $42^{\circ} 7.16^{\prime} \mathrm{W}$ & 802 & \\
\hline JC130_12 & M0075Z & 17,21 & 821 & $1 \mathrm{Dec}$ & $30^{\circ} 7.44^{\prime} \mathrm{N}$ & $42^{\circ} 7.16^{\prime} \mathrm{W}$ & 797 & \\
\hline
\end{tabular}

(high-resolution digital line scans and color reflectance spectrophotometry), and 21 subsamples ( $P$-wave velocity and moisture and density) taken from a range of lithologies across the study sites (see Physical properties in the Expedition 357 methods chapter [FrühGreen et al., 2017c]).

A negative correlation between magnetic susceptibility and electrical resistivity is relatively standard across most of the rock cores, whereas those parameters are positively correlated in sediment units. This may be attributed to fluid controlling resistivity in the sediment cores where the magnetic susceptibility and resistivity are both low. In hard rock cores, low porosity combined with the high proportion of magnetically susceptible components results in resistivity being controlled by the solid phases rather than any fluid present.

Density measurements on whole cores are primarily influenced by the quality of the core, and intervals of rubble are echoed in the scatter of the data profiles. Using gamma density in tandem with magnetic susceptibility can aid identification of certain lithologic boundaries, indicated by stepwise changes in the two parameters. For example, an interval of talc-amphibole-chlorite schist in Hole $\mathrm{M} 0068 \mathrm{~B}$ in the eastern area is characterized by lower densities and magnetic susceptibilities than the overlying (gabbroic) and underlying (ultramafic) units (see Lithology, alteration, and structure; see Figure F37 in the Eastern sites chapter [Früh-Green et al., 2017b]). 
Similarly, at the boundary between serpentinite and metagabbro at the base of Hole M0071A, a sharp decrease in magnetic susceptibility and increase in gamma density was observed.

Magnetic susceptibility does change overall from area to area, with western area cores having the highest magnetic susceptibility $\left(\right.$ mean $\left.=3591 \times 10^{-5} \mathrm{SI}\right)$ across the Atlantis Massif study site and northern area cores (dominated by sediment) having the lowest $\left(\right.$ mean $\left.=157 \times 10^{-5} \mathrm{SI}\right)$. The central and eastern areas are more comparable, with mean magnetic susceptibilities of $1187 \times 10^{-5}$ SI and $1280 \times 10^{-5} \mathrm{SI}$, respectively. A lower abundance of talc from the western area holes may be indicative of higher magnetite content in the recovered cores, compared to more talc-rich lithologies to the east (see Lithology, alteration, and structure). This hypothesis is supported by X-ray diffraction measurements of bulk rock samples, which show significantly higher amounts of magnetite in the west than in the other areas.

NGR intensities are consistently low across all sites, which is reasonable given the lithologies cored. The corresponding in situ data sets from three of the holes (M0068B, M0071C, and M0076B; see Downhole logging) may facilitate depth matching cores and logs to position the cores closer to their original in situ depth below seafloor.

In terms of recorded color reflectance parameters, the mean lightness $\left(\mathrm{L}^{*}\right)$ of cores is relatively constant across all four study areas (from $39.49 \%$ [central] to $44.98 \%$ [northern]). Color opponent dimension parameters are more variable. Mean $\mathrm{a}^{*}$ is negative at all but the northern sites, where the orange-colored sediment recovered from Site M0074 skews the data to positive (red). Mean b* is consistently positive (yellow) across the study areas. It is most positive in the northern (7.06) and central (3.03) areas because of the influence of the data from the sediment units at Site M0074 (northern) and Site M0069 (central).

Moisture and density analyses on samples reveal that the serpentinites form a discrete population with lower grain densities and slightly higher porosities compared to the schists, metadolerites, metagabbros, and gabbros (Figure F15). Calcareous sediment samples have similar grain densities to serpentinites but considerably higher porosities. It is difficult to comment on systematic changes in these parameters across Atlantis Massif because of the limited size of the data set.

Triaxial $P$-wave measurements were undertaken on all but the sediment minicore samples (Figure F16). Serpentinites yielded the

Figure F15. Porosity and grain density from all study areas, Expedition 357.

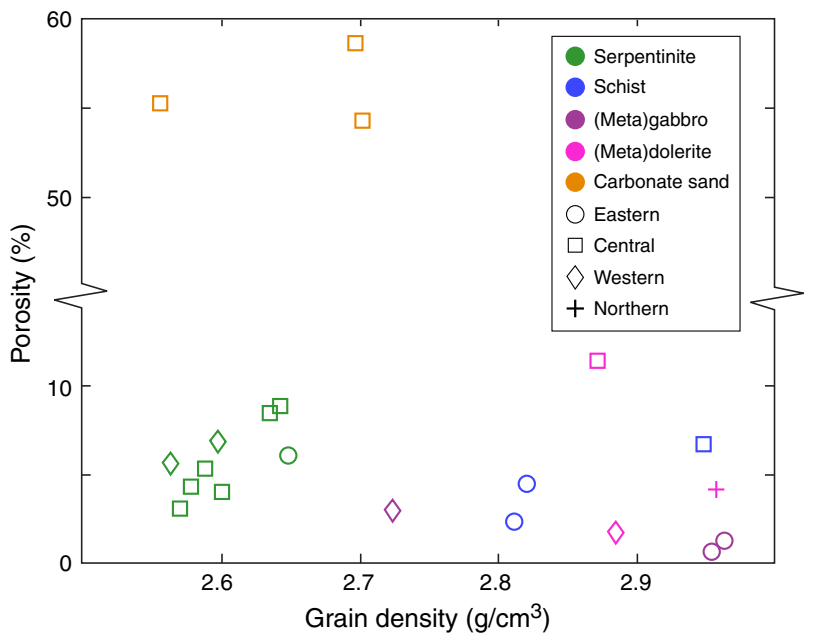

widest range of $P$-wave velocities of the lithologies sampled, ranging from 4.46 to $7.62 \mathrm{~km} / \mathrm{s}$ (values represent mean values of the triaxial measurements for each sample), with an overall mean of $5.94 \mathrm{~km} / \mathrm{s}$. The mafic rocks (metadolerites, metagabbros, and gabbros) have a narrower range of mean values, varying from 4.89 to $6.05 \mathrm{~km} / \mathrm{s}$ with an overall mean of $5.48 \mathrm{~km} / \mathrm{s}$. Schists have similar velocities to mafic rocks, with mean values from 4.41 to $6.68 \mathrm{~km} / \mathrm{s}$ and an overall mean of $5.26 \mathrm{~km} / \mathrm{s}$. No systematic changes in these velocities across the study areas were discerned based on this limited data set (18 samples). However, when relating the mean $(x-, y$-, $z$-direction) $P$-wave velocities to the corresponding porosity data, it is clear that the velocities are porosity controlled (Figure F16).

\section{Downhole logging}

During Expedition 357, 35 m of through-pipe total gamma ray logging measurements were acquired across three holes (M0068B [eastern], M0076B [central], and M0071C [western]). Other petrophysical measurements (notably resistivity and magnetic susceptibility) in the open hole were not possible for a variety of reasons, including boreholes too shallow for logging, boreholes obstructed by stuck core barrels and bottom-hole assemblies, and technical issues with the seabed drills that prevented tool deployment (see Offshore operations).

The total gamma ray data acquired indicate extremely low intensities of NGR from the lithologies encountered during this expedition across the three areas. Some similarities with the complementary data sets taken on whole-round cores may facilitate depth-matching core data to the downhole logs. This correlation could provide a better estimate of the original in situ depth of the core material, especially in lower recovery holes.

\section{Paleomagnetism}

Magnetic susceptibility (kappa; $\kappa$ ) and natural remanent magnetization (NRM) of 15 discrete cylinder samples (volume $=11 \mathrm{~cm}^{3}$ ) from the eastern, central, and western sites were measured during the OSP. Samples were taken from working halves and relatively oriented with respect to the top of the sampled cores. $\mathrm{K}$ ranges from 0.00031 to 0.0778 SI units (Table T7; Figure F17). The highest mag-

Figure F16. Porosity (from moisture and density analyses) and mean ( $x-, y-$, and $z$-direction) $P$-wave measurements from all study areas, Expedition 357. Bars $=$ minimum and maximum mean velocities. It was not possible to measure all three orthogonal directions for all samples.

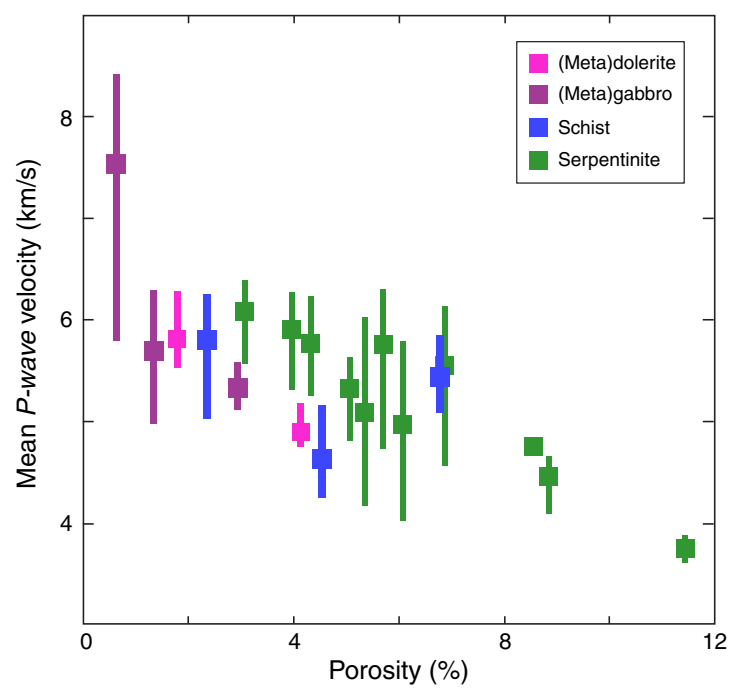


Table T7. Magnetic susceptibility Kappa values and demagnetized inclinations measured on discrete samples, Expedition 357. ND = not determined. Download table in .csv format.

\begin{tabular}{lcc}
\hline $\begin{array}{c}\text { Hole, core, section, } \\
\text { interval (cm) }\end{array}$ & $\begin{array}{c}\mathrm{K} \\
(\mathrm{SI})\end{array}$ & $\begin{array}{c}\text { Inclination } \\
\left({ }^{\circ}\right)\end{array}$ \\
\hline Eastern sites & & \\
M0068A-1R-1, 27.5 & 0.01380 & -3.7 \\
M0068B-1R-1, 129.5 & 0.00520 & -4.4 \\
M0068B-2R-1, 25 & 0.01265 & -3.3 \\
M0068B-4R-1,28 & 0.04470 & -3.2 \\
M0075B-3R-1,78 & 0.00386 & $\mathrm{ND}$ \\
Central sites & & \\
M0069A-5R-1, 104 & 0.00065 & -45.7 \\
M0069A-8R-1, 112 & 0.00065 & $\mathrm{ND}$ \\
M0069A-10R-10, 82 & 0.03386 & -41.9 \\
M0072B-8R-1, 28 & 0.01344 & -57.6 \\
M0076B-6R-1, 123.5 & 0.03706 & -49.1 \\
M0076B-8R-1, 87.5 & 0.01629 & -40.8 \\
Western sites & & \\
M0071A-1R-CC, 1.5 & 0.07780 & 39.0 \\
M0071A-1R-1, 21 & 0.05595 & 57.7 \\
M0071A-2R-1, 54 & 0.00031 & 57.3 \\
M0071C-6R-1, 16.5 & 0.00063 & -56.9 \\
\hline
\end{tabular}

Figure F17. Demagnetized inclinations vs. magnetic susceptibility for 13 discrete samples, Expedition 357. Red lines $=$ expected inclination of $\pm 49^{\circ}$.

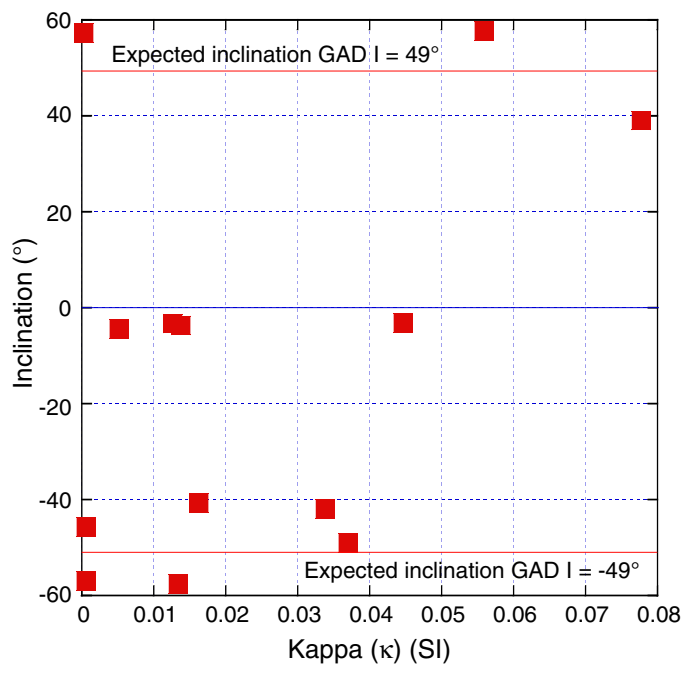

Figure F18. Declination and inclination from discrete samples $(N=13)$ after alternating field demagnetization up to $100 \mathrm{mT}$, Expedition 357 . Solid blue squares = samples with normal polarity NRM (positive inclinations), open red squares = samples with reversed NRM (negative inclinations). Magenta circles = GAD predictions for the highest (inner) and lowest (outer) site latitudes drilled.

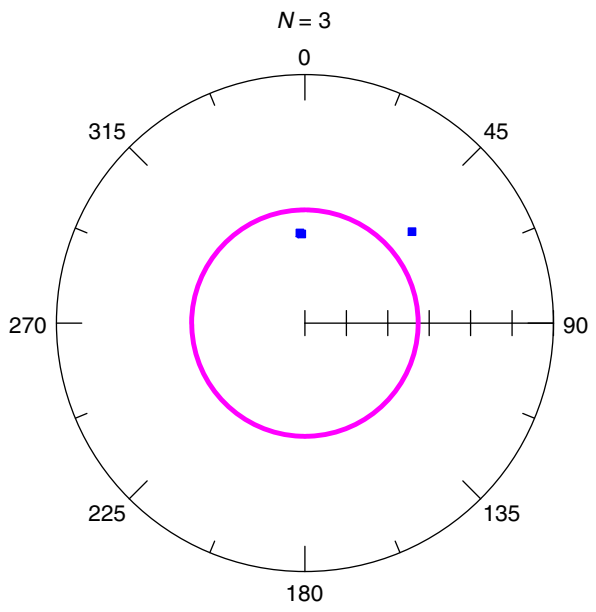

netic susceptibilities were displayed by serpentinized harzburgite, and the lowest $\kappa$ values were restricted to specimens of talc-amphibole-chlorite schist. Higher $\mathrm{k}$ values were frequently associated with more mafic rocks with greater abundances of iron oxide minerals such as magnetite. A viscous NRM component in the vast majority of discrete paleomagnetic pilot samples was effectively randomized by the application of an alternating field of 5-20 mT to determine inclinations and declinations of all the discrete samples (Table T7; Figure F18). Cores were not oriented with respect to an azimuth, and the relatively few sample points per core section limit the usefulness of the declination data. A distinct cluster of data points from the central sites varies only a few degrees from the predictions of a geocentric axial dipole (GAD) model. Notably, all of the samples from the eastern sites have shallow negative inclinations; these were all serpentinites. Additionally, multiple samples from the western sites (both metagabbro and serpentinized harzburgite) had positive inclinations.

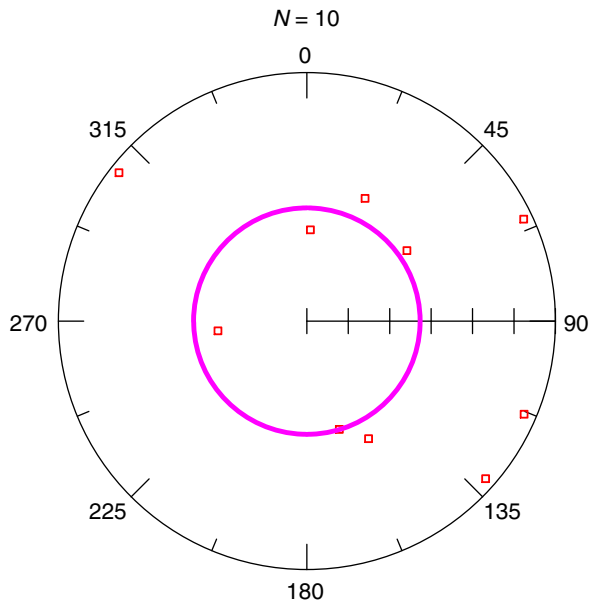

\section{Preliminary scientific assessment}

The overarching objectives of Expedition 357 focused on

- Exploring the extent and activity of the subsurface biosphere in young ultramafic and mafic seafloor;

- Quantifying the role of serpentinization in driving hydrothermal systems, sustaining microbiological communities, and sequestration of carbon in ultramafic rocks;

- Assessing how abiotic and biotic processes change with aging of the lithosphere and variations in rock type; and

- Characterizing tectonomagmatic processes that lead to lithospheric heterogeneities and the evolution of hydrothermal activity associated with detachment faulting.

To achieve these objectives, we set out to drill an east-west, spreading-parallel transect across the southern wall of Atlantis Massif and a south-north, ridge-parallel transect into the center of 
the massif (Figure F2). The east-west profile would allow evaluation of how microbial communities evolve with variations in hydrothermal activity and age of emplacement on the seafloor and of the extent and evolution of carbonate precipitation in serpentinizing peridotites. The south-north profile would allow evaluation of the deep biosphere in varying lithologies and provide information on the role of differing rheologies of gabbros and serpentinized ultramafic rocks in localizing detachment faults.

To accomplish these operations, we developed a coring and sampling strategy based on the use of seabed drills-the first time that such systems have been used in the ocean drilling programs. This technology was chosen with the hope of achieving high recovery of the carbonate cap sequences and intact contact and deformation sequences to $50 \mathrm{mbsf}$, which is generally difficult to achieve in hard rock with conventional ocean drilling technologies. The expedition plan also included several engineering developments to assess geochemical parameters during drilling; sample bottom water before and after coring; supply synthetic tracers during drilling for contamination assessment; acquire in situ electrical resistivity and magnetic susceptibility measurements for assessing fractures, fluid flows, and extent of serpentinization; and seal boreholes to provide opportunities for future experiments, all of which were supported and funded by IODP through ECORD. Although not an objective of the expedition, we were serendipitously able to generate a high-resolution (20 m per pixel) multibeam bathymetry map across the entire Atlantis Massif and nearby fracture zone, MAR, and eastern conjugate (Figure F6), taking advantage of weather and operational downtime. This map will assist science party members in evaluating and interpreting tectonic and mass-wasting processes operating on Atlantis Massif.

Expedition 357 successfully drilled 13 holes along the east-west transect of the southern wall of Atlantis Massif, including 4 holes on the eastern section, 6 in the carbonate cap and basement immediately north of the LCHF, and 3 on the western edge (Figures F2, F10). We also collected core from 4 holes north of the southern wall. In total, we collected $57 \mathrm{~m}$ of core with $55 \%$ overall core recovery (ranging from $0 \%$ at one site to $71 \%$ at another site and with $100 \%$ recovery in some sections). Many lithologic contacts and structural features are preserved in the cores (Figure F10), even in fractured units and shear intervals, which validates our choice of using seabed drills. Although penetration below $17 \mathrm{mbsf}$ proved impossible to achieve during the expedition because of the challenges of drilling in highly fractured and altered hard rock, we were successful in recovering the target rock type of moderately to highly altered and deformed serpentinized peridotites, gabbros, and mafic extrusive and dike rocks.

Core descriptions, structural measurements, and evaluation of the multibeam data during the onshore phase of the expedition provided an overview of the lithologic variations along the southern wall of Atlantis Massif. The lithologies along the east-west profile are dominated by highly serpentinized harzburgite with lesser dunite, with gabbroic veins and lenses, and show variable degrees of talc-amphibole-chlorite metasomatism and local rodingitization. Cores from the central sites (M0069, M0072, and M0076) recovered in situ continuous sections that preserve intrusive contacts and sheared intervals. These cores provide a record of early magmatism in the shallow mantle, multiphased and continuous serpentinization and metasomatism, injections of dolerite melts, and recent basaltic volcanism.
Cores from the eastern and western sites recovered variably sized blocks of rubble and sedimentary units. The rubble blocks consist of serpentinized harzburgite and dunite, metagabbros, dolerites, metadolerites, and sedimentary units dominated by basaltic breccias. The lithologies, deformation, and alteration characteristics in the rubble blocks are consistent with observations in the in situ sequences at the central sites; however, they provide no information as to the orientation of structures or veins. Surprisingly, the cores we recovered had only minor amounts of carbonate veins and no evidence for extensive carbonation.

Despite not reaching the target depths, 42 whole-round core samples for detailed microbiological and geochemical analyses were collected. Shipboard determination of contamination tracer delivery enabled confirmation of appropriate sample handling procedures for these samples, which will aid all subsequent microbiological investigations that are part of the science party sampling plans, as well as verification of this new tracer delivery technology for seabed drill rigs. Shipboard investigation of biomass density in select samples revealed relatively low and variable cell densities in the samples, and enrichment experiments set up shipboard will continue to be monitored for growth and activity. Thus, we anticipate achieving many of the deep biosphere-related objectives of the expedition through continued scientific investigation over the coming years. In combination with the anticipated microbiological results, shore-based petrological, structural, and geochemical studies will allow us to achieve a number of our goals set out for the east-west transect.

Unfortunately, we were unsuccessful in completing the southnorth operations planned for the expedition, which will limit our ability to satisfy objectives related to understanding detachment faults. Also, no open-hole logging operations could be conducted during the expedition due to a combination of technical issues and challenging hole conditions. However, we were able to demonstrate the functionality of the new magnetic susceptibility logging tool, which could have future applications for scientific and commercial ocean drilling research. NGR measurements were acquired through pipe in three holes, providing a complementary data set for the NGR measurements conducted prior to the OSP.

We were also successful in the application of other new technologies used in support of the expedition: (1) extensive use of a custom-designed in situ sensor package and water sampling system on the seabed drills for evaluating real-time dissolved methane, oxygen, $\mathrm{pH}, \mathrm{ORP}$, temperature, and conductivity during drilling; (2) deploying a borehole plug system for sealing seabed drill boreholes to allow access for future sampling; and (3) proving that contamination tracers can be delivered into drilling fluids on seabed drills. The sensor packages delivered valuable real-time data that provide important evidence that the ultramafic, and possibly volcanic, sequences are producing significant concentrations of hydrogen and methane during active serpentinization.

\section{Offshore operations}

\section{Transit to Atlantis Massif}

At $0950 \mathrm{~h}$ Universal Time Coordinated (UTC) on 26 October 2015, the Pilot joined the RRS James Cook. The vessel left the quayside at Southampton at $1021 \mathrm{~h}$, and the Pilot departed at $1141 \mathrm{~h}$. The vessel continued on transit toward the Atlantis Massif sites, arriving at the first site at $1530 \mathrm{~h}$ local time (UTC $-2 \mathrm{~h}$ ) on Thursday, 
5 November. All times hereafter will be in local time unless otherwise stated.

\section{Multibeam surveys and waiting on weather}

Preexisting bathymetric data sets included a regional $100 \mathrm{~m}$ resolution grid and a detailed $2 \mathrm{~m}$ resolution grid of the Lost City. However, there was an apparent offset between the two, potentially due to using different geographic projections. Therefore, prior to commencing coring operations, it was necessary to run a multibeam survey over the proposed coring sites to evaluate the slope angles for the drills and accurately locate the break in slope at the southern edge of the Atlantis Massif complex.

On 5 November 2015, in proximity to Site M0068 at $30^{\circ} 7.49717^{\prime} \mathrm{N}, 42^{\circ} 5.74742^{\prime} \mathrm{W}$, a sound velocity profile was conducted. The sonde was deployed at $1627 \mathrm{~h}$ and recovered to deck at $1741 \mathrm{~h}$. As data were downloaded, the vessel moved to the start of the first multibeam survey line. In total, five north-south survey lines were run, starting at $1814 \mathrm{~h}$ and ending at $2208 \mathrm{~h}$. This initial survey covered Sites M0068, M0069, M0071, M0072, and M0076. On 8 November, two multibeam lines were run in a northeastsouthwest direction to survey the locations for Sites M0070 and M0074. The survey commenced at $1027 \mathrm{~h}$ and was completed by $1145 \mathrm{~h}$.

On 12 November at $0830 \mathrm{~h}$ the Master of the Vessel decided to cease drilling operations because of concerns regarding the weather (aftereffects of Hurricane Kate). However, multibeam and CTD operations were still possible, and we decided to prepare for possible coring at Sites M0073 and M0075 by running these activities in advance of any coring at these locations. The vessel departed Site M0072 at $0900 \mathrm{~h}$ following recovery of the RD2 to deck and transited to the start of the first multibeam line. The vessel initially ran three lines: east-west to cover proposed Site AM-05A, west-east covering Site M0075, and then continued east to cover an additional CTD cast taken over the MAR. This initial multibeam survey commenced at $0928 \mathrm{~h}$ and was completed by $1220 \mathrm{~h}$ on 12 November. Following completion of the CTD cast at the MAR (see below) and Site M0073, another multibeam survey was started at $1900 \mathrm{~h}$ on 12 November and ran until $\sim 0800$ h on 13 November, when a CTD was conducted at Site M0074. This portion of the survey covered the western side of the Atlantis Massif complex.

Following the CTD cast at Site M0074 on 13 November, the vessel continued to be officially "waiting on weather" as far as drilling operations were concerned, so we continued running north-south multibeam lines across the Atlantis Massif complex. This started at $1150 \mathrm{~h}$ and continued until $2240 \mathrm{~h}$ when the weather became so bad that the survey had to be terminated so that the vessel could turn into the predominant weather direction and maintain a steady course, with winds from the southwest and $5 \mathrm{~m}$ swell from the northwest. The vessel maintained this course until the early hours of 14 November when operations began at Site M0075.

The vessel departed Site M0076 at 1900 h on 17 November. With both drills still undergoing repairs, we decided to continue the multibeam survey, concentrating on running east over the MAR and the conjugate margin to the Atlantis Massif complex. A total of five north-south lines were run starting at $1940 \mathrm{~h}$ on 17 November and ending at $0812 \mathrm{~h}$ on 18 November. The vessel then began to transit to Site M0071 to begin coring operations with the RD2.

Following deterioration of the weather conditions again and with the forecast not showing improvement, the vessel was put on "waiting on weather" status as far as coring operations were concerned on 19 November. The vessel departed Site M0071 at $1226 \mathrm{~h}$ on 19 November and transited toward the start of two multibeam lines planned to image the Atlantis Fracture Zone south of the Atlantis Massif complex. The survey commenced at $1315 \mathrm{~h}$ and ended at $2052 \mathrm{~h}$.

By this point, the weather had deteriorated so much that the multibeam data were badly affected. The Master ordered the vessel onto a southwest course, heading $246^{\circ}$ until further notice. The vessel spent the entire day of 20 November heading southwest and then south, trying to avoid the worst of the weather. On 21 November, we decided to turn the vessel back toward Atlantis Massif and track the bad weather north, aiming to arrive back on site in workable conditions. The vessel turned at $0500 \mathrm{~h}$.

At 2229 h on 21 November, despite marginal conditions (swell > $4.8 \mathrm{~m}$ ), the vessel slowed to $\sim 5 \mathrm{kt}$ to begin a multibeam line running back across the Atlantis Fracture Zone and toward the Atlantis Massif complex. The data quality was marginal. At $0027 \mathrm{~h}$ on 22 November, a new multibeam line was started running west to east along the foot of the massif complex to fill in some data gaps. However, the sea state was not conducive to running in this direction, causing the system to freeze and requiring restarting twice, with very poor data quality, and the line was terminated at $0243 \mathrm{~h}$. We decided to move to the eastern conjugate margin and begin a south to north oriented line that would run with the swell. This third line started at $0348 \mathrm{~h}$ on 22 November and continued until $0600 \mathrm{~h}$, when the vessel was turned toward Site M0070.

At 2013 h on 28 November, the vessel departed Site M0075 to recommence multibeam surveying while waiting on technical repairs to the RD2. The first line was the rerunning of a west to east line along the foot of Atlantis Massif because of the poor data quality acquired on 22 November. Following this run, the vessel moved to continue the north-south lines covering the eastern conjugate margin of Atlantis Massif. The survey commenced at $2215 \mathrm{~h}$ and ended at $0547 \mathrm{~h}$ on 29 November with the vessel transiting back to Site M0075 to restart coring operations.

At 1620 h on 30 November, the vessel departed from Site M0074 to begin further multibeam surveys over Atlantis Massif, the Atlantis Fracture Zone, and the eastern conjugate margin. Both seabed drills were nonoperational with repairs not able to be undertaken at sea. The decision was therefore made to supplement the multibeam already acquired by continuing to survey the area, with one break for an additional CTD cast over Lost City, so as to best utilize the operational time remaining before commencing the transit back to Southampton, UK. The multibeam survey began at $1645 \mathrm{~h}$ on 30 November, broke off at $0815 \mathrm{~h}$ on 1 December for the CTD cast, restarted at $1734 \mathrm{~h}$, and ran until $0200 \mathrm{~h}$ on 2 December, when the vessel began the transit.

\section{Additional CTDs}

In addition to conducting a CTD cast prior to beginning coring operations at every site, two additional CTDs were requested by offshore science party members while waiting on weather and unable to continue with coring operations. These additional casts were intended to capture the geochemical signature away from the main Lost City site and proposed coring locations, as unexpected levels of gases had been captured during the baseline CTDs prior to coring.

On 12 November, a CTD cast over the Atlantis Fracture Zone was conducted between 1220 and $1529 \mathrm{~h}$. The cast reached $\sim 2 \mathrm{~m}$ above the seafloor, with the deepest samples collected from $\sim 4135$ $\mathrm{m}$ water depth. Two Niskin bottles were fired at depth, and then two each were fired at a midway point in the water column. No nearsurface sample was collected from this site. This additional CTD 
site was linked to Site M0072 (the closest coring location) and given the prefix M0072X. See Tables T5 and T6 for details of all CTD casts and Niskin bottle depths. The vessel then began to transit to Site M0073 to conduct another precoring CTD cast.

On 14 November, a CTD cast over the MAR was conducted between 1229 and $1526 \mathrm{~h}$. The cast reached $\sim 2 \mathrm{~m}$ above the seafloor, with the deepest samples collected from $\sim 4221 \mathrm{~m}$ water depth. In this instance, the usual sampling strategy was not followed, and two bottles were fired near the seafloor, a further two approximately 100 $\mathrm{m}$ above that, and the final two approximately $200 \mathrm{~m}$ above seafloor. This additional CTD site was linked to Site M0075 (the closest coring location) and given the prefix M0075X (Tables T5, T6). The vessel then began to transit toward Site M0070.

On 1 December, a CTD cast was conducted in close proximity to Lost City. The CTD commenced at $1548 \mathrm{~h}$ and was completed by $1725 \mathrm{~h}$. The deepest samples were collected from $807 \mathrm{~m}$ water depth. Samples were collected at $\sim 807,802$, and $797 \mathrm{~m}$ water depth, based on a methane spike observed in the data. No near-surface sample was collected from this site. This additional CTD site was linked to Site M0072 (the closest coring location) and given the prefix M0072Z (Tables T5, T6). The vessel then returned to running a multibeam survey over the western and northern edges of the Atlantis Massif area.

\section{Drilling operations}

Operations at Expedition 357 drill sites are detailed in the site chapters:

- For Sites M0068 and M0075, see the Eastern sites chapter (Früh-Green et al., 2017b).

- For Sites M0069, M0072, and M0076, see the Central sites chapter (Früh-Green et al., 2017a).

- For Sites M0071 and M0073, see the Western sites chapter (Früh-Green et al., 2017e).

- For Sites M0070 and M0074, see the Northern sites chapter (Früh-Green et al., 2017d).

\section{Transit back to Southampton, UK}

The vessel departed from the Atlantis Massif survey area at 0200 $\mathrm{h}$ on 2 December 2015. The vessel arrived at the pilot station at the entrance to Southampton Water at $0600 \mathrm{~h}$ UTC on 11 December, and the Pilot came aboard at $0830 \mathrm{~h}$ UTC for the final approach into Southampton and the National Oceanography Centre Southampton quayside. The ropes were ashore by $1000 \mathrm{~h}$ UTC.

\section{Outreach and communication}

The primary objective of Expedition 357 outreach and communication efforts was to demonstrate the benefits and excitement of the expedition's science and the IODP program in general to the media, nongovernmental organizations, governments, the scientific community, and the general public.

To accomplish this objective, our primary efforts were publicity of the expedition's aims and findings to international media, focused on media and journalist networks developed within the IODP/ECORD community and through the scientific participants. Secondary efforts were focused on hosting web-logs during the expedition for the general public to follow along with the life of science at sea.

Targeted activities in support of the communication objective included
- Preparation of expedition promotional materials, including an expedition logo, flier, and briefing kit.

- Radio interviews with, for example, the British Broadcasting Corporation (BBC) for use on local and national news, as well as the BBC World Service.

- Organization of a media briefing prior to the start of the expedition. This briefing was held at the Foreign Press Office in London, England (UK), on 22 October 2015. The briefing included short presentations by the Co-Chief Scientists about the scientific aims of the expedition, followed by a question and answer session with journalists. This was followed by a small media briefing onboard the RRS James Cook for local journalists in Southampton.

- Organization of a second media event during the onshore phase of the expedition. This event was held on 1 February 2016 at MARUM and featured short presentations by the Co-Chief Scientists followed by interviews and tours of the laboratory facilities and core repository.

- Individual contacts and interviews of members of the science party with public relations services at their home institutions and with local media in different countries.

- Regular promotion of the expedition's accomplishments through posts on social media platforms such as Twitter.

These efforts were successful in gaining international attention for the expedition, which was featured in news articles in Finland, France, Germany, UK, and USA, as well as radio and TV segments with interviews from the Co-Chief Scientists and several scientific participants. The expedition's science is also targeted for feature in a news documentary.

\section{References}

Alt, J.C., and Shanks, W.C., III, 1998. Sulfur in serpentinized oceanic peridotites: serpentinization processes and microbial sulfate reduction. Journal of Geophysical Research: Solid Earth, 103(B5):9917-9929. http://dx.doi.org/10.1029/98JB00576

Alt, J.C., and Shanks, W.C., III, 2003. Serpentinization of abyssal peridotites from the MARK area, Mid-Atlantic Ridge: sulfur geochemistry and reaction modeling. Geochimica et Cosmochimica Acta, 67(4):641-653. http://dx.doi.org/10.1016/S0016-7037(02)01142-0

Alt, J.C., and Shanks, W.C., III, 2006. Stable isotope compositions of serpentinite seamounts in the Mariana forearc: serpentinization processes, fluid sources and sulfur metasomatism. Earth and Planetary Science Letters, 242(3-4):272-285. http://dx.doi.org/10.1016/j.epsl.2005.11.063

Andreani, M., Luquot, L., Gouze, P., Godard, M., Hoisé, E., and Gibert, B., 2009. Experimental study of carbon sequestration reactions controlled by the percolation of $\mathrm{CO}_{2}$-rich brine through peridotites. Environmental Science \& Technology, 43(4):1226-1231. http://dx.doi.org/10.1021/es8018429

Andreani, M., Mével, C., Boullier, A.-M., and Escartin, J., 2007. Dynamic control on serpentine crystallization in veins: constraints on hydration processes in oceanic peridotites. Geochemistry, Geophysics, Geosystems, 8(2):Q02012. http://dx.doi.org/10.1029/2006GC001373

Bach, W., and Klein, F., 2009. The petrology of seafloor rodingites: insights from geochemical reaction path modeling. Lithos, 112(1-2):103-117. http://dx.doi.org/10.1016/j.lithos.2008.10.022

Biddle, J.F., Lipp, J.S., Lever, M.A., Lloyd, K.G., Sørensen, K.B., Anderson, R., Fredricks, H.F., Elvert, M., Kelly, T.J., Schrag, D.P., Sogin, M.L., Brenchley, J.E., Teske, A., House, C.H., and Hinrichs, K.-U., 2006. Heterotrophic Archaea dominate sedimentary subsurface ecosystems off Peru. Proceedings of the National Academy of Sciences of the United States of America, 103(10):3846-3851. http://dx.doi.org/10.1073/pnas.0600035103 
Blackman, D.K., Karson, J.A., Kelley, D.S., Cann, J.R., Früh-Green, G.L., Gee, J.S., Hurst, S.D., John, B.E., Morgan, J., Nooner, S.L., Ross, D.K., Schroeder, T.J., and Williams, E.A., 2002. Geology of the Atlantis Massif (MidAtlantic Ridge, $30^{\circ} \mathrm{N}$ ): implications for the evolution of an ultramafic oceanic core complex. Marine Geophysical Research, 23(5-6):443-469. http://dx.doi.org/10.1023/B:MARI.0000018232.14085.75

Boschi, C., Dini, A., Dallai, L., Ruggieri, G., and Gianelli, G., 2009. Enhanced $\mathrm{CO}_{2}$-mineral sequestration by cyclic hydraulic fracturing and Si-rich fluid infiltration into serpentinites at Malentrata (Tuscany, Italy). Chemical Geology, 265(1-2):209-226. http://dx.doi.org/10.1016/j.chemgeo.2009.03.016

Boschi, C., Dini, A., Früh-Green, G.L., and Kelley, D.S., 2008. Isotopic and element exchange during serpentinization and metasomatism at the Atlantis Massif (MAR $30^{\circ} \mathrm{N}$ ): insights from $\mathrm{B}$ and Sr isotopes. Geochimica et Cosmochimica Acta, 72(7):1801-1823. http://dx.doi.org/10.1016/j.gca.2008.01.013

Boschi, C., Früh-Green, G.L., Delacour, A., Karson, J.A., and Kelley, D.S., 2006. Mass transfer and fluid flow during detachment faulting and development of an oceanic core complex, Atlantis Massif (MAR 30 N). Geochemistry, Geophysics, Geosystems, 7(1):Q01004. http://dx.doi.org/10.1029/2005GC001074

Bougault, H., Charlou, J.-L., Fouquet, Y., Needham, H.D., Vaslet, N., Appriou, P., Baptiste, P.J., Rona, P.A., Dmitriev, L., and Silantiev, S., 1993. Fast and slow spreading ridges: structure and hydrothermal activity, ultramafic topographic highs, and $\mathrm{CH}_{4}$ output. Journal of Geophysical Research: Solid Earth, 98(B6):9643-9651. http://dx.doi.org/10.1029/93JB00508

Bradley, A.S., Fredricks, H., Hinrichs, K.-U., and Summons, R.E., 2009a. Structural diversity of diether lipids in carbonate chimneys at the Lost City hydrothermal field. Organic Geochemistry, 40(12):1169-1178. http://dx.doi.org/10.1016/j.orggeochem.2009.09.004

Bradley, A.S., Hayes, J.M., and Summons, R.E., 2009b. Extraordinary ${ }^{13} \mathrm{C}$ enrichment of diether lipids at the Lost City hydrothermal field indicates a carbon-limited ecosystem. Geochimica et Cosmochimica Acta, 73(1):102-118. http://dx.doi.org/10.1016/j.gca.2008.10.005

Brazelton, W.J., and Baross, J.A., 2009. Abundant transposases encoded by the metagenome of a hydrothermal chimney biofilm. ISME Journal, 3(12):1420-1424. http://dx.doi.org/10.1038/ismej.2009.79

Brazelton, W.J., Ludwig, K.A., Sogin, M.L., Andreishcheva, E.N., Kelley, D.S., Shen, C.-C., Edwards, R.L., and Baross, J.A., 2010. Archaea and bacteria with surprising microdiversity show shifts in dominance over 1,000-year time scales in hydrothermal chimneys. Proceedings of the National Academy of Sciences of the United States of America, 107(4):1612-1671. http://dx.doi.org/10.1073/pnas.0905369107

Brazelton, W.J., Schrenk, M.O., Kelley, D.S., and Baross, J.A., 2006. Methaneand sulfur-metabolizing microbial communities dominate the Lost City hydrothermal field ecosystem. Applied and Environmental Microbiology, 72(9):6257-6270. http://dx.doi.org/10.1128/AEM.00574-06

Brazelton, W.J., Sogin, M.L., and Baross, J.A., 2009. Multiple scales of diversification within natural populations of archaea in hydrothermal chimney biofilms. Environmental Microbiology Reports, 2(2):236-242. http://dx.doi.org/10.1111/j.1758-2229.2009.00097.x

Campbell, B.J., Engel, A.S., Porter, M.L., and Takai, K., 2006. The versatile $\epsilon-$ proteobacteria: key players in sulphidic habitats. Nature Reviews Microbiology, 4(6):458-468. http://dx.doi.org/10.1038/nrmicro1414

Cann, J.R., Blackman, D.K., Smith, D.K., McAllister, E., Janssen, B., Mello, S., Avgerinos, E., Pascoe, A.R., and Escartin, J., 1997. Corrugated slip surfaces formed at ridge-transform intersections on the Mid-Atlantic Ridge. Nature, 385(6614):329-332. http://dx.doi.org/10.1038/385329a0

Cannat, M., 1993. Emplacement of mantle rocks in the seafloor at mid-ocean ridges. Journal of Geophysical Research: Solid Earth, 98(B3):4163-4172. http://dx.doi.org/10.1029/92JB02221

Cannat, M., Cann, J., and Maclennan, J., 2004. Some hard rock constraints on the supply of heat to mid-ocean ridges. In German, C.R., Lin, J., and Parson, L.M. (Eds.), Mid-Ocean Ridges: Hydrothermal Interactions Between the Lithosphere and Oceans. Geophysical Monograph, 148:111-149. http://dx.doi.org/10.1029/148GM05
Cannat, M., Sauter, D., Mendel, V., Ruellan, E., Okino, K., Escartin, J., Combier, V., and Baala, M., 2006. Modes of seafloor generation at a melt-poor ultraslow-spreading ridge. Geology, 34(7):605-608. http://dx.doi.org/10.1130/G22486.1

Charlou, J.L., Bougault, H., Appriou, P., Nelsen, T., and Rona, P., 1991. Different TDM $/ \mathrm{CH}_{4}$ hydrothermal plume signatures: TAG site at $26^{\circ} \mathrm{N}$ and serpentinized ultrabasic diapir at $15^{\circ} 05^{\prime} \mathrm{N}$ on the Mid-Atlantic Ridge. Geochimica et Cosmochimica Acta, 55(11):3209-3222. http://dx.doi.org/10.1016/0016-7037(91)90484-M

Charlou, J.L., Donval, J.P., Fouquet, Y., Jean-Baptiste, P., and Holm, N., 2002. Geochemistry of high $\mathrm{H}_{2}$ and $\mathrm{CH}_{4}$ vent fluids issuing from ultramafic rocks at the Rainbow hydrothermal field $\left(36^{\circ} 14^{\prime} \mathrm{N}, \mathrm{MAR}\right)$. Chemical Geology, 191(4):345-359. http://dx.doi.org/10.1016/S0009-2541(02)00134-1

Charlou, J.L., Fouquet, Y., Bougault, H., Donval, J.P., Etoubleau, J., Jean-Baptiste, P., Dapoigny, A., Appriou, P., and Rona, P.A., 1998. Intense $\mathrm{CH}_{4}$ plumes generated by serpentinization of ultramafic rocks at the intersection of the $15^{\circ} 20^{\prime} \mathrm{N}$ Fracture Zone and the Mid-Atlantic Ridge. Geochimica et Cosmochimica Acta, 62(13):2323-2333. http://dx.doi.org/10.1016/S0016-7037(98)00138-0

Delacour, A., Früh-Green, G.L., and Bernasconi, S.M., 2008a. Sulfur mineralogy and geochemistry of serpentinites and gabbros of the Atlantis Massif (IODP Site U1309). Geochimica et Cosmochimica Acta, 72(20):51115127. http://dx.doi.org/10.1016/j.gca.2008.07.018

Delacour, A., Früh-Green, G.L., Bernasconi, S.M., and Kelley, D.S., 2008b. Sulfur in peridotites and gabbros at Lost City $\left(30^{\circ} \mathrm{N}, \mathrm{MAR}\right)$ : implications for hydrothermal alteration and microbial activity during serpentinization. Geochimica et Cosmochimica Acta, 72(20):5090-5110. http://dx.doi.org/10.1016/j.gca.2008.07.017

Delacour, A., Früh-Green, G.L., Bernasconi, S.M., Schaeffer, P., and Kelley, D.S., 2008c. Carbon geochemistry of serpentinites in the Lost City hydrothermal system $\left(30^{\circ} \mathrm{N}, \mathrm{MAR}\right)$. Geochimica et Cosmochimica Acta, 72(15):3681-3702. http://dx.doi.org/10.1016/j.gca.2008.04.039

Delacour, A., Früh-Green, G.L., Frank, M., Gutjahr, M., and Kelley, D.S., 2008d. Sr- and Nd-isotope geochemistry of the Atlantis Massif $\left(30^{\circ} \mathrm{N}\right.$, MAR): implications for fluid fluxes and lithospheric heterogeneity. Chemical Geology, 254(1-2):19-35. http://dx.doi.org/10.1016/j.chemgeo.2008.05.018

deMartin, B.J., Sohn, R.A., Canales, J.P., and Humphris S.E., 2007. Kinematics and geometry of active detachment faulting beneath the Trans-Atlantic Geotraverse (TAG) hydrothermal field on the Mid-Atlantic Ridge. Geology, 35(8):711-741. http://dx.doi.org/10.1130/G23718A.1

Denny, A.R., Kelley, D.S., and Früh-Green, G.L., 2015. Geologic evolution of the Lost City hydrothermal field. Geochemistry, Geophysics, Geosystems, 17(2):375-394. http://dx.doi.org/10.1002/2015GC005869

D’Hondt, S., Jørgensen, B.B., Miller, D.J., Batzke, A., Blake, R., Cragg, B.A., Cypionka, H., Dickens, G.R., Ferdelman, T., Hinrichs, K.-U., Holm, N.G., Mitterer, R., Spivack, A., Wang, G., Bekins, B., Engelen, B., Ford, K., Gettemy, G., Rutherford, S.D., Sass, H., Skilbeck, C.G., Aiello, I.W., Guerin, G., House, C.H., Inagaki, F., Meister, P., Naehr, T., Niitsuma, S., Parkes, R.J., Schippers, A., Smith, D.C., Teske, A., Wiegel, J., Naranjo Padillo, C., and Solis Acosta, J.L., 2004. Distributions of microbial activities in deep subseafloor sediments. Science, 306(5705):2216-2221. http://dx.doi.org/10.1126/science.1101155

D'Hondt, S., Rutherford, S., and Spivack., A.J., 2002. Metabolic activity of subsurface life in deep-sea sediments. Science, 295(5562):2067-2070. http://dx.doi.org/10.1126/science.1064878

Dick, H.J.B., Lin, J., and Schouten, H., 2003. An ultraslow-spreading class of ocean ridge. Nature, 426(6965):405-412. http://dx.doi.org/10.1038/nature02128

Dick, H.J.B., Natland, J.H., Alt, J.C., Bach, W., Bideau, D., Gee, J.S., Haggas, S., Hertogen, J.G.H., Hirth, G., Holm, P.M., Ildefonse, B., Iturrino, G.J., John, B.E., Kelley, D.S., Kikawa, E., Kingdon, A., LeRoux, P.J., Maeda, J., Meyer, P.S., Miller, D.J., Naslund, H.R., Niu, Y.-L., Robinson, P.T., Snow, J., Stephen, R.A., Trimby, P.W., Worm, H.-U., and Yoshinobu, A., 2000. A long in situ section of the lower ocean crust: results of ODP Leg 176 drilling at 
the Southwest Indian Ridge. Earth and Planetary Science Letters, 179(1):31-51. http://dx.doi.org/10.1016/S0012-821X(00)00102-3

Dick, H.J.B., Tivey, M.A., and Tucholke, B.E., 2008. Plutonic foundation of a slow-spreading ridge segment: oceanic core complex at Kane Megamullion, $23^{\circ} 30^{\prime} \mathrm{N}, 45^{\circ} 20^{\prime} \mathrm{W}$. Geochemistry, Geophysics, Geosystems, 9(5):Q05014. http://dx.doi.org/10.1029/2007GC001645

Douville, E., Charlou, J.L., Donval, J.P., Knoery, J., and Fouquet, Y., 1997. Trace elements in fluids from the new Rainbow hydrothermal field $\left(36^{\circ} 14^{\prime} \mathrm{N}\right.$, MAR): a comparison with other Mid-Atlantic Ridge fluids. Eos, Transactions of the American Geophysical Union, 78:832.

Douville, E., Charlou, J.L., Oelkers, E.H., Bienvenu, P., Jove Colon, C.F., Donval, J.P., Fouquet, Y., Prieur, D., and Appriou, P., 2002. The Rainbow Vent fluids ( $\left.36^{\circ} 14^{\prime} \mathrm{N}, \mathrm{MAR}\right)$ : the influence of ultramafic rocks and phase separation on trace metal content in Mid-Atlantic Ridge hydrothermal fluids. Chemical Geology, 184(1-2):37-48. http://dx.doi.org/10.1016/S0009-2541(01)00351-5

Dupraz, C., Reid, R.P., Braissant, O., Decho, A.W., Norman, R.S., and Visscher, P.T., 2009. Processes of carbonate precipitation in modern microbial mats. Earth-Science Reviews, 96(3):141-162. http://dx.doi.org/10.1016/j.earscirev.2008.10.005

Ehrlich, H.L., 2009. Microbial formation and degradation of carbonates. In Ehrlich, H.L., and Newman, D.K. (Eds.), Geomicrobiology (5th edition): Boca Raton, FL (CRC Press), 157-191.

Escartín, J., Andreani, M., Hirth, G., and Evans, B., 2008. Relationships between the microstructural evolution and the rheology of talc at elevated pressures and temperatures. Earth and Planetary Science Letters, 268(3-4):463-475. http://dx.doi.org/10.1016/j.epsl.2008.02.004

Escartín, J., Mével, C., MacLeod, C.J., and McCaig, A.M., 2003. Constraints on deformation conditions and the origin of oceanic detachments: the MidAtlantic Ridge core complex at $15^{\circ} 45^{\prime} \mathrm{N}$. Geochemistry, Geophysics, Geosystems, 4(8):1067. http://dx.doi.org/10.1029/2002GC000472

Expedition 301 Scientists, 2005. Expedition 301 summary. In Fisher, A.T., Urabe, T., Klaus, A., and the Expedition 301 Scientists, Proceedings of the Integrated Ocean Drilling Program, 301: College Station, TX (Integrated Ocean Drilling Program Management International, Inc.). http://dx.doi.org/10.2204/iodp.proc.301.101.2005

Expedition 304/305 Scientists, 2006. Expedition 304/305 summary. In Blackman, D.K., Ildefonse, B., John, B.E., Ohara, Y., Miller, D.J., MacLeod, C.J., and the Expedition 304/305 Scientists, Proceedings of the Integrated Ocean Drilling Program, 304/305: College Station, TX (Integrated Ocean Drilling Program Management International, Inc.). http://dx.doi.org/10.2204/iodp.proc.304305.101.2006

Expedition Scientific Party, 2005a. Expedition 304 Preliminary Report: Oceanic Core Complex Formation, Atlantis Massif 1. Integrated Ocean Drilling Program. http://dx.doi.org/10.2204/iodp.pr.304.2005

Expedition Scientific Party, 2005b. Expedition 305 Preliminary Report: Oceanic Core Complex Formation, Atlantis Massif 2. Integrated Ocean Drilling Program. http://dx.doi.org/10.2204/iodp.pr.305.2005

Fisher, A.T., 1998. Permeability within basaltic oceanic crust. Reviews of Geophysics, 36(2):143-182. http://dx.doi.org/10.1029/97RG02916

Fisher, A.T., and Becker, K., 2000. Channelized fluid flow in oceanic crust reconciles heat-flow and permeability data. Nature, 403(6765):71-74. http://dx.doi.org/10.1038/47463

Foustoukos, D.I., and Seyfried, W.E., Jr., 2004. Hydrocarbons in hydrothermal vent fluids: the role of chromium-bearing catalysts. Science, 304(5673):1002-1005. http://dx.doi.org/10.1126/science.1096033

Frost, B.R., Beard, J.S., McCaig, A., and Condliffe, E., 2008. The formation of micro-rodingites from IODP Hole U1309D: key to understanding the process of serpentinization. Journal of Petrology, 49(9):1579-1588. http://dx.doi.org/10.1093/petrology/egn038

Früh-Green, G.L., Connolly, J.A.D., Plas, A., Kelley, D.S., and Grobéty, B., 2004. Serpentinization of oceanic peridotites: implications for geochemical cycles and biological activity. In Wilcock, W.S.D., DeLong, E.F., Kelley, D.S., Baross, J.A., and Cary, C. (Eds.), The Subseafloor Biosphere at MidOcean Ridges. Geophysical Monograph, 144:119-136. http://onlinelibrary.wiley.com/doi/10.1029/144GM08/summary
Früh-Green, G.L., Kelley, D.S., Bernasconi, S.M., Karson, J.A., Ludwig, K.A., Butterfield, D.A., Boschi, C., and Proskurowksi, G., 2003. 30,000 years of hydrothermal activity at the Lost City vent field. Science, 301(5632):495498. http://dx.doi.org/10.1126/science.1085582

Früh-Green, G.L., Orcutt, B.N., Green, S.L., Cotterill, C., Morgan, S., Akizawa, N., Bayrakci, G., Behrmann, J.-H., Boschi, C., Brazleton, W.J., Cannat, M., Dunkel, K.G., Escartin, J., Harris, M., Herrero-Bervera, E., Hesse, K., John, B.E., Lang, S.Q., Lilley, M.D., Liu, H.-Q., Mayhew, L.E., McCaig, A.M., Menez, B., Morono, Y., Quéméneur, M., Rouméjon, S., Sandaruwan Ratnayake, A., Schrenk, M.O., Schwarzenbach, E.M., Twing, K.I., Weis, D., Whattham, S.A., Williams, M., and Zhao, R., 2017a. Central sites. In Früh-Green, G.L., Orcutt, B.N., Green, S.L., Cotterill, C., and the Expedition 357 Scientists, Atlantis Massif Serpentinization and Life. Proceedings of the International Ocean Discovery Program, 357: College Station, TX (International Ocean Discovery Program). http://dx.doi.org/10.14379/iodp.proc.357.104.2017

Früh-Green, G.L., Orcutt, B.N., Green, S.L., Cotterill, C., Morgan, S., Akizawa, N., Bayrakci, G., Behrmann, J.-H., Boschi, C., Brazleton, W.J., Cannat, M., Dunkel, K.G., Escartin, J., Harris, M., Herrero-Bervera, E., Hesse, K., John, B.E., Lang, S.Q., Lilley, M.D., Liu, H.-Q., Mayhew, L.E., McCaig, A.M., Menez, B., Morono, Y., Quéméneur, M., Rouméjon, S., Sandaruwan Ratnayake, A., Schrenk, M.O., Schwarzenbach, E.M., Twing, K.I., Weis, D., Whattham, S.A., Williams, M., and Zhao, R., 2017b. Eastern sites. In Früh-Green, G.L., Orcutt, B.N., Green, S.L., Cotterill, C., and the Expedition 357 Scientists, Atlantis Massif Serpentinization and Life. Proceedings of the International Ocean Discovery Program, 357: College Station, TX (International Ocean Discovery Program). http://dx.doi.org/10.14379/iodp.proc.357.103.2017

Früh-Green, G.L., Orcutt, B.N., Green, S.L., Cotterill, C., Morgan, S., Akizawa, N., Bayrakci, G., Behrmann, J.-H., Boschi, C., Brazleton, W.J., Cannat, M., Dunkel, K.G., Escartin, J., Harris, M., Herrero-Bervera, E., Hesse, K., John, B.E., Lang, S.Q., Lilley, M.D., Liu, H.-Q., Mayhew, L.E., McCaig, A.M., Menez, B., Morono, Y., Quéméneur, M., Rouméjon, S., Sandaruwan Ratnayake, A., Schrenk, M.O., Schwarzenbach, E.M., Twing, K.I., Weis, D., Whattham, S.A., Williams, M., and Zhao, R., 2017c. Expedition 357 methods. In Früh-Green, G.L., Orcutt, B.N., Green, S.L., Cotterill, C., and the Expedition 357 Scientists, Atlantis Massif Serpentinization and Life. Proceedings of the International Ocean Discovery Program, 357: College Station, TX (International Ocean Discovery Program). http://dx.doi.org/10.14379/iodp.proc.357.102.2017

Früh-Green, G.L., Orcutt, B.N., Green, S.L., Cotterill, C., Morgan, S., Akizawa, N., Bayrakci, G., Behrmann, J.-H., Boschi, C., Brazleton, W.J., Cannat, M., Dunkel, K.G., Escartin, J., Harris, M., Herrero-Bervera, E., Hesse, K., John, B.E., Lang, S.Q., Lilley, M.D., Liu, H.-Q., Mayhew, L.E., McCaig, A.M., Menez, B., Morono, Y., Quéméneur, M., Rouméjon, S., Sandaruwan Ratnayake, A., Schrenk, M.O., Schwarzenbach, E.M., Twing, K.I., Weis, D., Whattham, S.A., Williams, M., and Zhao, R., 2017d. Western sites. In Früh-Green, G.L., Orcutt, B.N., Green, S.L., Cotterill, C., and the Expedition 357 Scientists, Atlantis Massif Serpentinization and Life. Proceedings of the International Ocean Discovery Program, 357: College Station, TX (International Ocean Discovery Program). http://dx.doi.org/10.14379/iodp.proc.357.105.2017

Früh-Green, G.L., Orcutt, B.N., Green, S.L., Cotterill, C., Morgan, S., Akizawa, N., Bayrakci, G., Behrmann, J.-H., Boschi, C., Brazleton, W.J., Cannat, M., Dunkel, K.G., Escartin, J., Harris, M., Herrero-Bervera, E., Hesse, K., John, B.E., Lang, S.Q., Lilley, M.D., Liu, H.-Q., Mayhew, L.E., McCaig, A.M., Menez, B., Morono, Y., Quéméneur, M., Rouméjon, S., Sandaruwan Ratnayake, A., Schrenk, M.O., Schwarzenbach, E.M., Twing, K.I., Weis, D., Whattham, S.A., Williams, M., and Zhao, R., 2017e. Northern sites. In Früh-Green, G.L., Orcutt, B.N., Green, S.L., Cotterill, C., and the Expedition 357 Scientists, Atlantis Massif Serpentinization and Life. Proceedings of the International Ocean Discovery Program, 357: College Station, TX (International Ocean Discovery Program). http://dx.doi.org/10.14379/iodp.proc.357.106.2017 
German, C.R., Thurnherr, A.M., Knoery, J., Charlou, J.L., Jean-Baptiste, P., and Edmonds, H.N., 2009. Export fluxes from submarine venting to the ocean: a synthesis of results from the Rainbow hydrothermal field, $36^{\circ} \mathrm{N}$ MAR. Geochimica et Cosmochimica Acta, 73(13)(Supplement):A428. http://dx.doi.org/10.1016/j.gca.2009.05.025

Godard, M., Awaji, S., Hansen, H., Hellebrand, E., Brunelli, D., Johnson, K., Yamasaki, T., Maeda, J., Abratis, M., Christie, D., Kato, Y., Mariet, C., and Rosner, M., 2009. Geochemistry of a long in-situ section of intrusive slowspread oceanic lithosphere: results from IODP Site U1309 (Atlantis Massif, $30^{\circ} \mathrm{N}$ Mid-Atlantic-Ridge). Earth and Planetary Science Letters, 279(1-2):110-122. http://dx.doi.org/10.1016/j.epsl.2008.12.034

Gold, T., 1979. Terrestrial sources of carbon and earthquake outgassing. Journal of Petroleum Geology, 1(3):3-19.

http://dx.doi.org/10.1111/j.1747-5457.1979.tb00616.x

Gold, T., 1999. The Deep Hot Biosphere: The Myth of Fossil Fuels: New York (Springer-Verlag).

Grimes, C.B., John, B.E., Cheadle, M.J., and Wooden, J.L., 2008. Protracted construction of gabbroic crust at a slow spreading ridge: constraints from ${ }^{206} \mathrm{~Pb} /{ }^{238} \mathrm{U}$ zircon ages from Atlantis Massif and IODP Hole U1309D (30 N, MAR). Geochemistry, Geophysics, Geosystems, 9:Q08012. http://dx.doi.org/10.1029/2008GC002063

Haggerty, J.A., 1991. Evidence from fluid seeps atop serpentine seamounts in the Mariana forearc: clues for emplacement of the seamounts and their relationship to forearc tectonics. Marine Geology, 102(1-4):293-309. http://dx.doi.org/10.1016/0025-3227(91)90013-T

Hinrichs, K.-U., Hayes, J.M., Bach, W., Spivack, A.J., Hmelo, L.R., Holm, N.G., Johnson, C.G., and Sylva, S.P., 2006. Biological formation of ethane and propane in the deep marine subsurface. Proceedings of the National Academy of Science of the United States of America, 103(40):14684-14689. http://dx.doi.org/10.1073/pnas.0606535103

Holm, N.G., and Andersson, E.M., 1998. Hydrothermal systems. In Brack, A. (Ed.), The Molecular Origins of Life: Assembling Pieces of the Puzzle. Cambridge, United Kingdom (Cambridge University Press), 86-99. http://dx.doi.org/10.1017/CBO9780511626180.006

Holm, N.G., and Charlou, J.L., 2001. Initial indications of abiotic formation of hydrocarbons in the Rainbow ultramafic hydrothermal system, MidAtlantic Ridge. Earth and Planetary Science Letters, 191(1-2):1-8. http://dx.doi.org/10.1016/S0012-821X(01)00397-1

Huber, J.A., Butterfield, D.A., and Baross, J.A., 2002. Temporal changes in archaeal diversity and chemistry in a mid-ocean ridge subseafloor habitat. Applied Environmental Microbiology, 68(4):1585-1594. http://dx.doi.org/10.1128/AEM.68.4.1585-1594.2002

Huber, J.A., Butterfield, D.A., and Baross, J.A., 2003. Bacterial diversity in a subseafloor habitat following a deep-sea volcanic eruption. FEMS Microbiology Ecology, 43(3): 393-409. http://dx.doi.org/10.1111/j.1574-6941.2003.tb01080.x

Humphris, S.E., and Cann, J.R., 2000. Constraints on the energy and chemical balances of the modern TAG and ancient Cyprus seafloor sulfide deposits. Journal of Geophysical Research: Solid Earth, 105(B12):28477-28488. http://dx.doi.org/10.1029/2000JB900289

Ildefonse, B., Blackman, D.K., John, B.E., Ohara, Y., Miller, D.J., MacLeod, C.J., and Integrated Ocean Drilling Program Expeditions 304/305 Science Party, 2007. Oceanic core complexes and crustal accretion at slowspreading ridges. Geology, 35(7):623-626. http://dx.doi.org/10.1130/G23531A.1

Inagaki, F., Nunoura, T., Nakagawa, S., Teske, A., Lever, M., Lauer, A., Suzuki, M., Takai, K., Delwiche, M., Colwell, F.S., Nealson, K.H., Horikoshi, K., D'Hondt, S., and Jørgensen, B.B., 2006. Biogeographical distribution and diversity of microbes in methane hydrate-bearing deep marine sediments on the Pacific Ocean margin. Proceedings of the National Academy of Sciences of the United States of America, 103(8):2815-2820. http://dx.doi.org/10.1073/pnas.0511033103

Jöns, N., Bach, W., and Schroeder, T., 2009. Formation and alteration of plagiogranites in an ultramafic-hosted detachment fault at the MidAtlantic Ridge (ODP Leg 209). Contributions to Mineralogy and Petrology, 157(5):625-639. http://dx.doi.org/10.1007/s00410-008-0357-2
Karson, J.A., Früh-Green, G.L., Kelley, D.S., Williams, E.A., Yoerger, D.R., and Jakuba, M., 2006. Detachment shear zone of the Atlantis Massif core complex, Mid-Atlantic Ridge, $30^{\circ} \mathrm{N}$. Geochemistry, Geophysics, Geosystems, 7(6):Q06016. http://dx.doi.org/10.1029/2005GC001109

Kelemen, P.B., Kikawa, E., Miller, D.J., and Shipboard Scientific Party, 2007. Leg 209 summary: processes in a 20-km-thick conductive boundary layer beneath the Mid-Atlantic Ridge, $14^{\circ}-16^{\circ} \mathrm{N}$. In Kelemen, P.B., Kikawa, E., and Miller, D.J. (Eds.), Proceedings of the Ocean Drilling Program, Scientific Results, 209: College Station, TX (Ocean Drilling Program), 1-33. http://dx.doi.org/10.2973/odp.proc.sr.209.001.2007

Kelemen, P.B., and Matter, J., 2008. In situ carbonation of peridotite for $\mathrm{CO}_{2}$ storage. Proceedings of the National Academy of Sciences of the United States of America, 105(45):17295-17300. http://dx.doi.org/10.1073/pnas.0805794105

Kelley, D.S., Karson, J.A., Blackman, D.K., Früh-Green, G.L., Butterfield, D.A., Lilley, M.D., Olson, E.J., Schrenk, M.O., Roe, K.K., Lebon, G.T., Rivizzigno, P., and the AT3-60 Shipboard Party, 2001. An off-axis hydrothermal vent field near the Mid-Atlantic Ridge at $30^{\circ} \mathrm{N}$. Nature, 412(6843):145-149. http://dx.doi.org/10.1038/35084000

Kelley, D.S., Karson, J.A., Früh-Green, G.L., Yoerger, D.R., Shank, T.M., Butterfield, D.A., Hayes, J.M., Schrenk, M.O., Olson, E.J., Proskurowski, G., Jakuba, M., Bradley, A., Larson, B., Ludwig, K., Glickson, D., Buckman, K., Bradley, A.S., Brazelton, W.J., Roe, K., Elend, M.J., Delacour, A., Bernasconi, S.M., Lilley, M.D., Baross, J.A., Summons, R.E., and Sylva, S.P., 2005. A serpentinite-hosted ecosystem: the Lost City hydrothermal field. Science, 307(5714):1428-1434.

http://dx.doi.org/10.1126/science.1102556

Konn, C., Charlou, J.L., Donval, J.P., Holm, N.G., Dehairs, F., and Bouillon, S., 2009. Hydrocarbons and oxidized organic compounds in hydrothermal fluids from Rainbow and Lost City ultramafic-hosted vents. Chemical Geology, 258(3-4):299-314.

http://dx.doi.org/10.1016/j.chemgeo.2008.10.034

Lalou, C., Reyss, J.-L., Brichet, E., Rona, P.A., and Thompson, G., 1995. Hydrothermal activity on a $10^{5}$-year scale at a slow-spreading ridge, TAG hydrothermal field, Mid-Atlantic Ridge $26^{\circ} \mathrm{N}$. Journal of Geophysical Research: Solid Earth, 100(B9):17855-17862.

http://dx.doi.org/10.1029/95JB01858

Lang, S.Q., Butterfield, D.A., Schulte, M., Kelley, D.S., and Lilley, M.D., 2010. Elevated concentrations of formate, acetate and dissolved organic carbon found at the Lost City hydrothermal field. Geochimica et Cosmochimica Acta, 74(3):941-952. http://dx.doi.org/10.1016/j.gca.2009.10.045

Lang, S.Q., Früh-Green, G.L., Bernasconi, S.M., Lilley, M.D., Proskurowski, G., Méhay, S., and Butterfield, D.A., 2012. Microbial utilization of abiogenic carbon and hydrogen in a serpentinite-hosted system. Geochimica et Cosmochimica Acta, 92:82-99. http://dx.doi.org/10.1016/j.gca.2012.06.006

Lipp, J.S., Morono, Y., Inagaki, F., and Hinrichs, K.-U., 2008. Significant contribution of Archaea to extant biomass in marine subsurface sediments. Nature, 454(7207):991-994. http://dx.doi.org/10.1038/nature07174

Ludwig, K.A., Kelley, D.S., Butterfield, D.A., Nelson, B.K., and Früh-Green, G., 2006. Formation and evolution of carbonate chimneys at the Lost City hydrothermal field. Geochimica et Cosmochimica Acta, 70(14):36253645. http://dx.doi.org/10.1016/j.gca.2006.04.016

Ludwig, K.A., Shen, C.-C., Kelley, D.S., Cheng, H., and Edwards, R.L., 2011. $\mathrm{U}$-Th systematics and ${ }^{230} \mathrm{Th}$ ages of carbonate chimneys at the Lost City hydrothermal field. Geochimica et Cosmochimica Acta, 75(7):1869-1888. http://dx.doi.org/10.1016/j.gca.2011.01.008

Mason, O.U., Nakagawa, T., Rosner, M., Van Nostrand, J.D., Zhou, J., Maruyama, A., Fisk, M.R., and Giovannoni, S.J., 2010. First investigation of the microbiology of the deepest layer of ocean crust. PLoS One, 5(11):e15399. http://dx.doi.org/10.1371/journal.pone.0015399

McCaig, A.M., Cliff, R.A., Escartin, J., Fallick, A.E., and MacLeod, C.J., 2007. Oceanic detachment faults focus very large volumes of black smoker fluids. Geology, 35(10):935-938. http://dx.doi.org/10.1130/G23657A.1

McCaig, A.M., Delacour, A., Fallick, A.E., Castelain, T., and Früh-Green, G.L., 2010. Detachment fault control on hydrothermal circulation systems: 
interpreting the subsurface beneath the TAG hydrothermal field using the isotopic and geological evolution of oceanic core complexes in the Atlantic. In Rona, P.A., Devey, C.W., Dyment, J., and Murton, B.J. (Eds.), Diversity of Hydrothermal Systems on Slow Spreading Ocean Ridges. Geophysical Monograph, 188:207-239. http://onlinelibrary.wiley.com/doi/10.1029/2008GM000729/summary

McCollom, T.M., 2007. Geochemical constraints on sources of metabolic energy for chemolithoautotrophy in ultramafic-hosted deep-sea hydrothermal systems. Astrobiology, 7(6):933-950. http://dx.doi.org/10.1089/ast.2006.0119

McCollom, T.M., and Seewald, J.S., 2001. A reassessment of the potential for reduction of dissolved $\mathrm{CO}_{2}$ to hydrocarbons during serpentinization of olivine. Geochimica et Cosmochimica Acta, 65(21):3769-3778. http://dx.doi.org/10.1016/S0016-7037(01)00655-X

McCollom, T.M., and Seewald., J.S., 2003. Experimental constraints on the hydrothermal reactivity of organic acids and acid anions: I. Formic acid and formate. Geochimica et Cosmochimica Acta, 67(19):3625-3644. http://dx.doi.org/10.1016/S0016-7037(03)00136-4

McCollom, T.M., and Seewald, J.S., 2006. Carbon isotope composition of organic compounds produced by abiotic synthesis under hydrothermal conditions. Earth and Planetary Science Letters, 243(1-2):74-84. http://dx.doi.org/10.1016/j.epsl.2006.01.027

McCollom, T.M., and Shock, E.L., 1997. Geochemical constraints on chemolithoautotrophic metabolism by microorganisms in seafloor hydrothermal systems. Geochimica et Cosmochimica Acta, 61(20):4375-4391. http://dx.doi.org/10.1016/S0016-7037(97)00241-X

Méhay, S., Früh-Green, G.L., and Bernasconi, S.M., 2009. S-cycling and sulfurization processes at the Lost City hydrothermal field. Geochimica et Cosmochimica Acta, 73(13)(Supplement):A864. http://dx.doi.org/10.1016/j.gca.2009.05.011

Méhay, S., Früh-Green, G.L., Lang, S.Q., Bernasconi, S.M., Brazelton, W.J., Schrenk, M.O., Schaeffer, P., and Adam, P., 2013. Record of archaeal activity at the serpentinite-hosted Lost City hydrothermal field. Geobiology, 11(6):570-592. http://dx.doi.org/10.1111/gbi.12062

Mehta, M.P., and. Baross, J.A., 2006. Nitrogen fixation at $92^{\circ} \mathrm{C}$ by a hydrothermal vent archaeon. Science, 314(5806):1783-1786. http://dx.doi.org/10.1126/science.1134772

Michibayashi, K., Hirose, T., Nozaka, T., Hariagane, Y., Escartin, J., Delius, H., Linek, M., and Ohara, Y., 2008. Hydration due to high-T brittle failure within in situ oceanic crust, $30^{\circ} \mathrm{N}$ Mid-Atlantic Ridge. Earth and Planetary Science Letters, 275(3-4):348-354.

http://dx.doi.org/10.1016/j.epsl.2008.08.033

Moore, D.E., and Rymer, M.J., 2007. Talc-bearing serpentinite and the creeping section of the San Andreas fault. Nature, 448(7155):795-797. http://dx.doi.org/10.1038/nature06064

Morris, A., Gee, J.S., Pressling, N., John, B.E., MacLeod, C.J., Grimes, C.B., and Searle, R.C., 2009. Footwall rotation in an oceanic core complex quantified using reoriented Integrated Ocean Drilling Program core samples. Earth and Planetary Science Letters, 287(1-2):217-228. http://dx.doi.org/10.1016/j.epsl.2009.08.007

Mottl, M.J., and Haggerty, J.A., 1989. Upwelling of Cl-poor, S- and C-rich waters through a serpentinite seamount, Mariana forearc, ODP Leg 125. Eos, Transactions of the American Geophysical Union, 70:1382. http://dx.doi.org/10.1029/89EO00329

Nakagawa, S., Inagaki, F., Suzuki, Y., Steinsbu, B.O., Lever, M.A., Takai, K., Engelen, B., Sako, Y., Wheat, C.G., Horikoshi, K., and Integrated Ocean Drilling Program Expedition 301 Scientists, 2006. Microbial community in black rust exposed to hot ridge-flank crustal fluids. Applied Environmental Microbiology, 72(10):6789-6799.

http://dx.doi.org/10.1128/AEM.01238-06

Nercessian, O., Fouquet, Y., Pierre, C., Prieur, D., and Jeanthon, C., 2005. Diversity of bacteria and archaea associated with a carbonate-rich metalliferous sediment sample from the Rainbow vent field on the Mid-Atlantic Ridge. Environmental Microbiology, 7(5):608-714. http://dx.doi.org/10.1111/j.1462-2920.2005.00744.x

Ohara, Y., Stern, R.J., Ishii, T., Yurimoto, H., and Yamazaki, T., 2002. Peridotites from the Mariana Trough: first look at the mantle beneath an active back-arc basin. Contributions to Mineralogy and Petrology, 143(1):1-18. http://dx.doi.org/10.1007/s00410-001-0329-2

Ohara, Y., Yoshida, T., Kato, Y., and Kasuga, S., 2001. Giant megamullion in the Parece Vela backarc basin. Marine Geophysical Research, 22(1):47-61. http://dx.doi.org/10.1023/A:1004818225642

Orphan, V.J., House, C.H., Hinrichs, K.-U., McKeegan, K.D., and DeLong, E.F., 2001. Methane-consuming archaea revealed by directly coupled isotopic and phylogenetic analysis. Science, 293(5529):484-487. http://dx.doi.org/10.1126/science.1061338

Parkes, R.J., Webster, G., Cragg, B.A., Weightman, A.J., Newberry, C.J., Ferdelman, T.G., Kallmeyer, J., Jørgensen, B.B., Aiello, I.W., and Fry, J.C., 2005. Deep sub-seafloor prokaryotes stimulated at interfaces over geological time. Nature, 436(7049):390-394. http://dx.doi.org/10.1038/nature03796

Perner, M., Kuever, J., Seifert, R., Pape, T., Koschinsky, A., Schmidt, K., Straus, H., and Imhoff, J.F., 2007. The influence of ultramafic rocks on microbial communities at the Logatchev hydrothermal field, located $15^{\circ} \mathrm{N}$ on the Mid-Atlantic Ridge. FEMS Microbiology Ecology, 61(1):97-109. http://dx.doi.org/10.1111/j.1574-6941.2007.00325.x

Proskurowski, G., Lilley, M.D., and Brown, T.A., 2004. Isotopic evidence of magmatism and seawater bicarbonate removal at the Endeavour hydrothermal system. Earth and Planetary Science Letters, 225(1-2):53-61. http://dx.doi.org/10.1016/j.epsl.2004.06.007

Proskurowski, G., Lilley, M.D., Kelley, D.S., and Olson, E.J., 2006. Low temperature volatile production at the Lost City hydrothermal field, evidence from a hydrogen stable isotope geothermometer. Chemical Geology, 229(4):331-343. http://dx.doi.org/10.1016/j.chemgeo.2005.11.005

Proskurowski, G., Lilley, M.D., Seewald, J.S., Früh-Green, G.L., Olson, E.J., Lupton, J.E., Sylva, S.P., and Kelley, D.S., 2008. Abiogenic hydrocarbon production at Lost City hydrothermal field. Science, 319(5863):604-607. http://dx.doi.org/10.1126/science.1151194

Reinen, L.A., Weeks, J.D., and Tullis, T.E., 1991. The frictional behavior of serpentinite: implications for aseismic creep on shallow crustal faults. Geophysical Research Letters, 18(10):1921-1924. http://dx.doi.org/10.1029/91GL02367

Rona, P.A., Bougault, H., Charlou, J.L., Appriou, P., Nelsen, T.A., Trefry, J.H., Eberhart, G.L., Barone, A., and Needham, H.D., 1992. Hydrothermal circulation, serpentinization, and degassing at a rift valley-fracture zone intersection: Mid-Atlantic Ridge near $15^{\circ} \mathrm{N}, 45^{\circ} \mathrm{W}$. Geology, 20(9):783786. http://dx.doi.org/10.1130/00917613(1992)020<0783:HCSADA>2.3.CO;2

Rona, P.A., Hannington, M.D., Raman, C.V., Thompson, G., Tivey, M.K., Humphris, S.E., Lalou, C., and Petersen, S., 1993. Active and relict seafloor hydrothermal mineralization at the TAG hydrothermal field, MidAtlantic Ridge. Economic Geology, 88(8):1989-2013. http://dx.doi.org/10.2113/gsecongeo.88.8.1989

Russell, M.J., 2003. The importance of being alkaline. Science, 302(5645):580581.http://dx.doi.org/10.1126/science.1091765

Sagalevich, A.M., Vinogradov, G.M., Gurvich, E.G., Lein, A.Y., Lukashin, V.N., and Chernyaev, E.S., 2000. Investigations in the Titanic study area and the Rainbow hydrothermal field in Cruise 42 of the research vessel Akademik Mstislav Keldysh. Oceanology, 40:439-446.

Schrenk, M.O., Kelley, D.S., Bolton, S.A., and Baross, J.A., 2004. Low archaeal diversity linked to subseafloor geochemical processes at the Lost City hydrothermal field, Mid-Atlantic Ridge. Environmental Microbiology, 6:1086-1095. http://dx.doi.org/10.1111/j.1462-2920.2004.00650.x

Schroeder, T., John, B., and Frost, B.R., 2002. Geologic implications of seawater circulation through peridotite exposed at slow-spreading midocean ridges. Geology, 30(4):367-370. http://dx.doi.org/10.1130/00917613(2002)030<0367:GIOSCT >2.0.CO;2

Schroeder, T., and John, B.E., 2004. Strain localization on an oceanic detachment fault system, Atlantis Massif, $30^{\circ} \mathrm{N}$, Mid-Atlantic Ridge. Geochemistry, Geophysics, Geosystems, 5:Q11007. http://dx.doi.org/10.1029/2004GC000728

Scruggs, V.J., 1997. Frictional constitutive properties and related microstructures of albite, muscovite, biotite and talc [Ph.D. dissert.]. Brown University, Providence, Rhode Island. 
Shipboard Scientific Party, 2003. Leg 201 summary. In D’Hondt, S.L., Jørgensen, B.B., Miller, D.J., et al., Proceedings of the Ocean Drilling Program, Initial Reports, 201: College Station, TX (Ocean Drilling Program), 1-81. http://dx.doi.org/10.2973/odp.proc.ir.201.101.2003

Shock, E.L., and Schulte, M.D., 1998. Organic synthesis during fluid mixing in hydrothermal systems. Journal of Geophysical Research: Planets, 103(E12):28513-28527. http://dx.doi.org/10.1029/98JE02142

Sleep, N.H., Meibom, A., Fridriksson, T., Coleman, R.G., and Bird, D.K., 2004. $\mathrm{H}_{2}$-rich fluids from serpentinization: geochemical and biotic implications. Proceedings of the National Academy of Sciences of the United States of America, 101(35):12818-12823. http://dx.doi.org/10.1073/pnas.0405289101

Smith, D.K., Cann, J.R., and Escartin, J., 2006. Widespread active detachment faulting and core complex formation near $13^{\circ} \mathrm{N}$ on the Mid-Atlantic Ridge. Nature, 442(7101):440-443. http://dx.doi.org/10.1038/nature04950

Smith, D.K., Escartín, J., Schouten, H., and Cann, J.R., 2008. Fault rotation and core complex formation: significant processes in seafloor formation at slow-spreading mid-ocean ridges (Mid-Atlantic Ridge, $13^{\circ}-15^{\circ} \mathrm{N}$ ). Geochemistry, Geophysics, Geosystems, 9(3):Q03003. http://dx.doi.org/10.1029/2007GC001699

Summit, M., and Baross, J.A., 2001. A novel microbial habitat in the midocean ridge subseafloor. Proceedings of the National Academy of Sciences of the United States of America, 98(5):2158-2163. http://dx.doi.org/10.1073/pnas.051516098

Sun, S.-S., and McDonough, W.F., 1989. Chemical and isotopic systematics of oceanic basalts: implications for mantle composition and processes. In
Saunders, A.D., and Norry, M.J. (Eds.), Magmatism in the Ocean Basins. Geological Society Special Publication, 42:313-345.

http://dx.doi.org/10.1144/GSL.SP.1989.042.01.19

Szatmari, P., 1989. Petroleum formation by Fischer-Tropsch synthesis in plate tectonics. AAPG Bulletin, 73(8):989-998. http://dx.doi.org/10.1306/44B4A2CB-170A-11D78645000102C1865D

Takai, K., Gamo, T., Tsunogai, U., Nakayama, N., Hirayama, H., Nealson, K.H., and Horikoshi, K., 2004. Geochemical and microbiological evidence for a hydrogen-based, hyperthermophilic subsurface lithoautotrophic microbial ecosystem (HyperSLiME) beneath an active deep-sea hydrothermal field. Extremophiles, 8(4):269-282. http://dx.doi.org/10.1007/s00792-004-0386-3

Tucholke, B.E., Behn, M.D., Buck, W.R., and Lin, J., 2008. Role of melt supply in oceanic detachment faulting and formation of megamullions. Geology, 36(6):455-458. http://dx.doi.org/10.1130/G24639A.1

Wheat, C.G., and Fisher, A.T., 2008. Massive, low-temperature hydrothermal flow from a basaltic outcrop on $23 \mathrm{Ma}$ seafloor of the Cocos plate: chemical constraints and implications. Geochemistry, Geophysics, Geosystems, 9(12):Q12O14. http://dx.doi.org/10.1029/2008GC002136

Wheat, C.G., Jannasch, H.W., Kastner, M., Plant, J.N., and DeCarlo, E.H., 2003. Seawater transport and reaction in upper oceanic basaltic basement: chemical data from continuous monitoring of sealed boreholes in a ridge flank environment. Earth and Planetary Science Letters, 216(4):549-564. http://dx.doi.org/10.1016/S0012-821X(03)00549-1 